2. To: (Receiving Organization)

TWRS SAR Engineering

5. Proj./Prog./Dept./Div.:

$8 M 400$

8. Originator Remarks:

The attached document is submitted for approval and release.

1. Receiver Remarks:

$\mathrm{N} / \mathrm{A}$
3. From: (Originating Organization)

TWRS SA? Engineering

6. Cog. Engr.:

B. W. $\left.\mathrm{H}_{1}\right] 1$

1. EDT $\{42241$

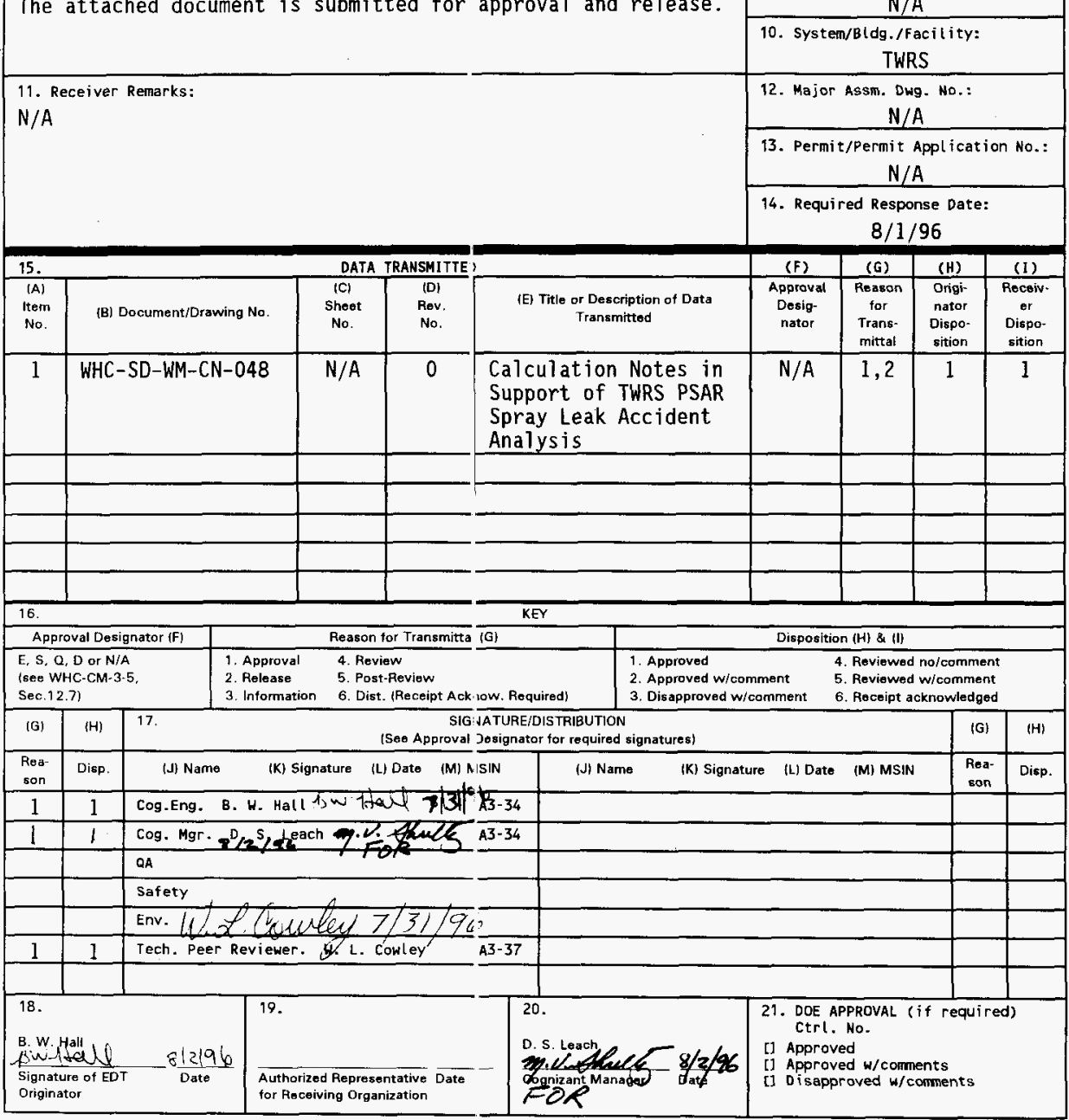

BD-7400-172-2 (04/94) GEF097 


\title{
Calculation Notes in Support of TWRS FSAR Spray Leak Accident Analysis
}

\author{
B. W. Hall
}

Westinghouse Hanford Company, Richland, WA 99352

U.S. Department of Energy Contract DE-AC06-87RL10930

$\begin{array}{lll}\text { EDT/ECN: } & 142241 & \text { UC: } 510 \\ \text { Org Code: } & 8 \text { M400 } & \text { Crarge Code: N1FC3 } \\ \text { B\&R Code: } & \text { EW31220071 } & \text { Tctal Pages: } 10099 \\ & & \end{array}$

Key Words: spray, aerosols, TWRS, jumper, dispersion, dose

Abstract: This document includes the calculations needed to quantify the risk associated with unnitigated and mitigated pressurized spray releases from tank farm traisfer equipment inside transfer enclosures. The calculations within this document support the spray leak accident analysis reported in the TWRS FSAR.

TRADEMARK DISCLAIMER. Reference herei, to any specific comercial product, process, or service by trade name, trademark, manufacturer, ${ }^{\circ}$ otherwise, does not necessarily constitute or imply its endorsement, recommendation, or favori:g by the United States Government or any agency thereof or its contractors or subcontractors.

Printed in the United States of Americ.. To obtain copies of this document, contact: WHC/BCS Document Control Services, P.O. Box 19'0, Mailstop H6-08, Richland WA 99352, Phone (509) 372-2420; Fax (509) 376-4989.
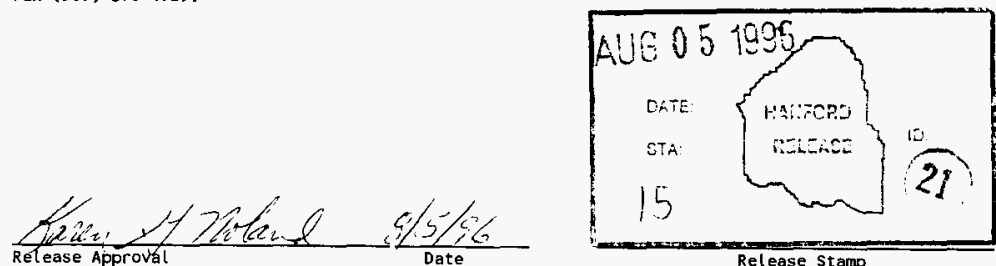

Release Starip

\section{Approved for Public Release}




$$
\text { WHC-SD-WM-CN-C48, REV O }
$$

Calculation Notes in Support of TWRS FSAR Spray Leak Accident Analys is WitC- SD-WM-CN-048 Revision 0

Safety Analysis and Nuclear Engineering

1 of 98 


\section{WHC-5D-WM-CN-048 ReU O}

\section{C INTRODUCTION}

This document contains the letailed calculations that support the spray leak accident analysis in the Tanl: Waste Remediation System (TWRS) Final Safety Analys is Report (FSAR) (WHI:-SD-WM-SAR-067, 1996). The consequence analyses in this document form thi: basis for the selection of controls to mitigate or prevent spray leaks t/ıroughout TWRS.

Pressurized spray leaks can occur due to a breach in containment barriers along transfer routes, during waste transfers. Spray leaks are of particular safety concern because depending on leak dimensions, and waste pressure, they can be relatively ifficient generators of dispersible sized aerosols that can transport downw nd to onsite and offsite receptors.

Waste is transferred betweell storage tanks and between processing facilities and storage tanks in THRS through a system of buried transfer lines. Pumps for transferring wa:te and jumpers and valves for rerouting waste are located inside below gride pits and structures that are normally covered. Pressurized spray leaks can emanate to the atmosphere due to breaches in waste transfer associated equipment inside these structures should the structures be uncovered at the time of the leak. Pressurized spray leaks can develop through holes or cracls in transfer piping, valve bodies or pump casings caused by such mechanisms as corrosion, erosion, thermal stress, or water hammer. Leaks through degrided valve packing, jumper gaskets, or pump seals can also result in pressurized spray releases. Mechanisms that can degrade seals, packing and gaskets include aging, radiation hardening, thermal stress, etc. Another common cause for spray leaks inside transfer enclosures are misaligned jumpers caused by luman error.

A spray leak inside a DST vilve pit during a transfer of aging waste was selected as the bounding, represertative accident for detailed analysis.

Sections 2 through 5 below develof this representative accident using the DOESTD-3009 format. Sections 2 describes the unmitigated and mitigated accident scenarios evaluated to determine the need for safety class SSCS or TSR controls. Section 3 develops the source terms associated with the unmitigated and mitigated accident scenarios. Section 4 estimates the radiological and toxicological consequences for the unmitigated and mitigated scenarios. Section 5 compares the radiological and toxicological consequences against the TWRS evaluation guidelines.

Section 6 extrapolates from the representative accident case to other represented spray leak sites to assess the conservatism in using the representative case to define controls for other postulated spray leak sites throughout TWRS. Section 7 discusses the sensitivities of the consequence analyses to the key parameters and assumptions used in the analyses. Conclusions are drawn in Section $\varepsilon$.

The analyses herein pertain to spray leaks initiated due to internal mechanisms (e.g., corrosion, erosion, thermal stress, etc). External initiators of spray leaks (e.g., excavation accidents), and natural phenomena initiators (e.g., seismic events) are to be covered in separate accident analyses.

\section{2 of 98}


WHC-SP-WM-CW-O48 Keva

\subsection{SI ENARIO DEVELOPMENT}

This section describes the Inmitigated and mitigated accident scenarios for the valve pit spray leak, and estimates the frequency range associated with the unmitigated and mitigated scenarios to allow for comparison against evaluation guidelines.

\subsection{UNMITIGATED ACCIDENT SCENARI )}

\subsubsection{Scenario Description.}

Spray leaks inside valve piis can develop due to breaches in the pressure boundary of piping, jumpirs, or valves. Leaks in piping, jumpers, or valve bodies can develop due to such mechanisms as erosion, corrosion, thermal stress, fatigue, weld flaws, manu acturing flaws, etc. Leaks at jumper connections to transfer pipes can occur due to human error (misalignment of the jumper), or gasket failure. 1/alves can leak through valve stem packing or seals. Gaskets, packing and seal:; degrade due to radiation hardening, aging, and thermal stress. Valve seals i:an also leak due to torque generated in jumper connections.

For the unmitigated scenariu, it is postulated that a spray leak develops in a valve pit due to ons of the mechanisms discussed above. (The initiating mechanism is not important to the analysis as mitigation rather than prevention of the initiator las found to be the best solution to the spray leak problem.) The spray is postulated to occur during a transfer of aging waste through the pit. Agirg waste is selected for the bounding analysis as it produces the highe: $t$ dose, on a per liter basis, of all tank waste types.

The unmitigated analysis as: umes away all preventative and mitigative barriers for the purpose of detern ining the need for safety class or safety significant SSCS and TSR controls. It is therefore assumed that the pit cover blocks (which are the primary barrier to release) are off at the time of the leak. Such an unmitigated release could occur if the cover blocks are not replaced following a jumper change or maintenance activity in the pit and a subsequent transfer is made throuch that pit, or if cover blocks are inadvertently removed during a trinsfer, or if waste is misrouted through a pit where jumper change or mainterance activities are ongoing. The spray is postulated, due to its momentum, to emit up and out of the pit directly into the atmosphere.

The uncovered spray leak is assumed to continue unabated for 24 hours. The onsite receptor is assumed to be exposed to the plume of aerosols generated in the accident for 12 hours (this duration accounts for a work shift with possible overtime). The offsite receptor is assumed to be exposed to the entire passage of the plume, or 24 hours. It is arbitrarily assumed that the pump is shutoff at 24 hours. Although it is possible the leak could continue longer than this, this duration is sufficient to determine the safety class ramifications of the accident. The sensitivity of the analysis to assumed accident duration is discussed in Section 8.

\subsubsection{Unmitigated Accident Freque ccy}

$$
3 \text { of } 98
$$


$u-i c-5 D-n M-C N-048$, eevo

The unmitigated accident fraquency is assigned based on the frequency of the initiating event only. In this case, the initiating event is a spray leak from equipment inside the pit. The conditional probability that the cover blocks are off at the time of the spray leak is not factored into the frequency assignment.

The initiating event is considered to be in the Anticipated frequency category ( $1 \mathrm{E}-2$ events/yr to 1 evelit/yr), when applied to the many valve pits across the tank farm. This frequency category is assigned based on Hanford site experience. The table in Appendix A summarizes occurrence reports relating to leaks from transfer eluipment inside process pits or diversion boxes. This table covers events back to 1972 . Fourteen events are included in the table where waste or contaninated water was found to have leaked during transfers or during flushing from failed equipment in pump pits, valve pits, sluice pits, or flush pits. In fuur of the occurrence reports involving leaks into pits, the leaks are specificially described as sprays. The remaining ten leaks were found after the fact and may have been been sprays or low pressure 1 iquid releases where aerosol generation would be greatly reduced.

Note that in occurrence repert 77-205, the spray leak occurred during a leak test while the cover blocks were removed from the pit. Contaminated water was sprayed onto two workers standing outside the pit.

\subsection{MITIGATED ACCIDENT SCENARIO}

\subsubsection{Scenario Description}

The primary mitigative barriers to a valve pit spray leak are the valve pit cover blocks. These blocks, when in place, knock down the spray and impede the release of aerosols to the atmosphere. For the mitigated scenario, it is thus postulated that the spray leak occurs with the pit covers in place.

The cover blocks are the only potentially effective existing barrier to limit the consequences of the spray release. Efficient aerosol generating spray leaks occur through small orifices or narrow cracks. Pit leak detectors are not sensitive enough to detect low flowrate spray leaks. The liquid fraction of release may dribble down the sides of the drain pipe from the pit without contacting the conductivity probes. The consequence analysis below shows that the doses from an unmitigated spray leak are very large in a short period of time for the onsite receptor. For pits with leak detectors in sumps, the time required to buildup enough liquid to set of the leak detector would be too long to prevent unacceptable consequences to the onsite receptor.

Mass balances performed every two hours during transfers are also not sensitive enough to detect the small amount of material lost in a spray leak. A half inch discrepancy in the recsipt tank generally warrants a shutdown of transfer pumps. For double shell storage tanks, the half inch discrepancy corresponds to a material loss of 1375 gallons. Leak quantities much smaller than this are shown below to produze onsite and offsite consequences in excess of evaluation guidelines.

Since no effective controls axist to limit the duration of the spray leak, the mitigated spray leak is issumed to continue for the same duration as the unmitigated scenario, or 24 hodrs. As in the unmitigated scenario, the

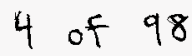




\section{WHC-SD-WM-CN-O48 RevO}

onsite receptor is assumed to be exposed for 12 hours, the offsite receptor for 24 hours.

The mitigated scenario allo'ss for the examination of the effectiveness of the cover blocks as the only mitigative barrier to the release.

\subsubsection{Mitigated Accident Frequen:y}

The mitigated accident frequency category is Anticipated. The frequency category is the same as for the ulmitigated accident scenario because no safety SSCS or TSR controls are cedited with reducing the likelihood of the initiating event. 


$$
\text { WHC-SD-WM-CN-OY8 ReVO }
$$

\subsection{SOURCE TERM ANALYSIS}

The waste postulated to be :sprayed in both the unmitigated and mitigated scenarios is aging waste, contain ng 33 vol \% entrained solids. Aging waste slurry is selected for bounding arlalyses because aging waste solids produce the highest dose of all waste typus, based on the unit liter dose (ULD) factors reported in WHC-CM-SARR-0;7 (1996). The ULDs for aging waste, DST waste, and SST waste from SARR-03: are reproduced in Table 4-1.

33 vol \% entrained solids it the maximum expected solids loading during transfers. This solids loading vilue is considered to be bounding. The upper operating limit of the 242-A evapcrator, which produces the most concentrated slurry currently transferred in the tank farms, is $30 \mathrm{vol} \%$ solids. Level readings in receipt tanks indicate that the entrained solids content in most supernate transfers is very small (e.g., the feed tank to the 242-A evaporator is not full of solids, despite the fact that millions of gallons of waste have been run through the evaporator). Grab samples taken from supernate layers in waste storage tanks typically measure trace amounts to 5 vol \% solids. There is some concern however that submersible and saltwell pumps lowered near sludge layers could entrain much more than 5 vol \% solids during individual transfers. The solids are assumec to spray through the leakage path in proportion to the solids content in the waste being pumped through the transfer line. The sensitivity of the consequence analysis results to assumed solids content is discussed in Section 8 , including the potential for plugging of the leakage path with waste solids.

The following subsections quantify the aerosol releases of aging waste to the atmosphere for the unmitigated and mitigated scenarios, respectively.

\subsection{UNMITIGATED ACCIDENT SOURCE TERM}

The SPRAY model was used to determine the flowrate and particle size distribution of the aerosols generated in the unmitigated spray release. For a detailed description of the spray model, see WHC-SD-GN-SWD-20007 (1994). In summary, SPRAY determines the total leak rate and aerosol particle size distribution based on the dimensions of the orifice or crack that is postulated to have caused the leak, the fluid pressure, the fluid viscosity, and the fluid density. SPRAY first determines the leakage flowrate and jet velocity exiting the orifice or crack using Bernoulli's equation. Cracks or orifices that are efficient generators of aerosols are very small, so the depth of the orifice or crack can se large in comparison to the diameter or width of the orifice or crack. Hence, frictional losses across the depth of the leakage path can be significant. The Darcy frictional losses across the depth of the crack are calculated sy SPRAY by entering the depth of the leakage path, and the surface rouginess of the leakage path as inputs. The liquid stream exiting the orifice or crack disintegrates due to turbulence and aerodynamic drag forces exerted by the surrounding air. SPRAY estimates the Sauter Mean Diameter (SMD) of the :Iroplets formed based on the hydraulic radius of the orifice or slit, the kinematic viscosity of the liquid, and the liquid jet velocity, using an empi-ical correlation. From the SMD, the particle size distribution of the zerosol is calculated using the RosinRammler distribution (Rosin and Rarmler 1933). The SPRAY code has a 


\section{WHC-SR- EN $-C N-048$ ReV O}

subroutine to iteratively solve for the orifice diameter or crack width that produces the maximum flowrate of crosols below a requested size.

\subsubsection{SPRAY InPut}

For the purposes of modelling this accident, the spray leak was assumed to occur at a misaligned jumper cinnection to a 2 in., schedule 40 slurry transfer 1 ine. The leak was assulled to be $5.1 \mathrm{~cm}$ (2 in.) 1ong. This leak length was selected because it re|resents, roughly, the fraction of the jumper connection circumference that cou d orient a spray up and out of an uncovered pit. This length is judged to be conservative for longitudinal cracks that might develop in pipes. To facto' in the Darcy frictional losses across the depth of the leakage path, an equ valent crack depth of $0.391 \mathrm{~cm}$ (the thickness of a 2 in., Schedule 40 pipe) was entered into the code. The walls of the leakage path were assumed :o have a surface roughness equivalent to that of steel, or $0.0046 \mathrm{~cm}$.

The leak was assumed to occir at a maximum waste gauge pressure of 2.1 MPa (300 psi). This maximum wasti: pressure was selected based on a review of DST and AWF transfer pump performince curves. Appendix B contains the pump curves obtained for various trans er pumps throughout TWRS. The 300 ps $i$ limit was set based on the pump curve for the cross site transfer pump in Tank 102-SY. From Appendix B, the shut off head for this pump is $410 \mathrm{ft}$ for a fluid with an SpG of 1.7 . This coverts to pressure as follows:

102-sY Deadhead Pump Pressure $=(410 \mathrm{ft})(1.7 \mathrm{f} 1$ water $/ \mathrm{ft}$ of slurry $)(14.7 \mathrm{psi} / 33.9 \mathrm{ft}$ water $)$ $=300$ psig.

The 300 psi assumption is boundinc for all pumps considered except the PB-2 pump in the 242-A evaporator. The variable speed drive PB-2 pump can produce pressures higher than $300 \mathrm{psi}$ at - ts highest RPM setting. However, a rupture disk and a PRV are provided in the evaporator to 1 imit pressure in transfer lines to less than $250 \mathrm{psi}$.

Because of the high shear rite induced in the spray leak, the thixotropic waste slurry was assuned to have a viscosity approaching that of water, or $1 \mathrm{cPs}$.

At 33 vol\% solids, aerosols up to $14.5 \mu \mathrm{m}$ in diameter can evaporate down to their solids constituents in the respirable $(10 \mu \mathrm{m})$ size range after being emitted into the atmosphere. This can be determined using the following equation, which assumes spherically shaped particles:

$$
\begin{aligned}
& D_{i}=\left(D_{f}^{3} / E\right)^{1 / 3} \\
& \text { Where, } \\
& D_{i}=\text { diameter of initial aerssol } \\
& D_{f}=\text { diameter of final aerossl } \\
& E^{=} \text {volume fraction of solids in initial aerosol. }
\end{aligned}
$$

The SPRAY code was used to iteratively solve for the crack width that produced the maximum flow rate particles $15 \mu \mathrm{m}$ in diameter and less. The sub-15 $\mu \mathrm{m}$

\section{7 of 98}




$$
W H C-S C 1-W M-C N-048 \text { ReV } O
$$

particles are treated as respirab ${ }^{\circ}$ in the consequence calculations in Section 4.

\subsubsection{SPRAY Results}

The input and output files from the SPRAY run are included in Appendix C (see case 1). The optimum crack vidth was found to be $1.1 \mathrm{E}-2 \mathrm{~cm}$. The velocity of the jet issuing from the crack was found to be $26.5 \mathrm{~m} / \mathrm{s}$. The total flow rate through the optimim-sized leak was found to be $9.20 \mathrm{~L} / \mathrm{min}$. The respirable aerosol release rate from the spray was found to be $0.21 \mathrm{~L} / \mathrm{min}$, giving a respirable release fraction of $2.3 \%$. Over a 12 -hour period (i.e., exposure duration for the onsite receptor), this release rate corresponds to a total volumetric release of waste material in the respirable size range of 150 L. Over a 24-hour period, the total volume of waste released in the respirable size range is $300 \mathrm{~L}$.

\subsection{MITIGATED ACCIDENT SOURCE TEFM}

In the mitigated accident, the pit covers provide an impaction surface that prevents the jetting of aerosols directly into the atmosphere. The covers also create a relatively stagnant air volume that fosters agglomeration and rainout of aerosols within the pit. Aerosol removal also occurs due to condensation on the pit walls and the underside of the cover blocks. Aerosol is further removed from any air expelled from the pit through the cover block gaps because the leakage paths are tortuous and provide additional surfaces for impingement and condensation.

For the mitigated analysis it is assumed that any air expelled from the pit would be limited in aerosol concentration to the quasi-stable aerosol loading limit of $100 \mathrm{mg} / \mathrm{m}^{3}$ (PNL-41;4, Section 2.4 .14 and BNWL, Appendix C). Use of this value is considered to be conservative. For comparison purposes typical fog measures $10 \mathrm{mg} / \mathrm{m}^{3}$ (PNL-2844, Appendix A). The aerosols expelled from the pit are all conservatively assumed to be in the respirable size range (less than $10 \mu \mathrm{m}$ in diameter).

The cover blocks are not sealed and thus do not ensure confinement of aerosols. Gaps around cover blocks, gaps around plugs in the drain ports, access gaps around camera hatches, and valve handle penetrations provide leakage paths for some of the aerosol generated in the spray to be expelled from the pit.

The valve pit drain is conne:ted to a ventilated DST. Normally, this vent system ensures a slightly negative pressure in the pit. Under spray leak conditions, however, a resulting temperature and humidity increase in the pit air could cause a volume expansion of the air that overcomes the draw of the DST ventilation system. There is also the possibility that the pit drain could be plugged (some drains are slugged by design to allow buildup for leak detectors to work), in which case she liquid spilining to the pit floor would also displace aerosol-laden air from the pit.

\subsubsection{Air Expulsion due to Temper iture and Humidity Increase}

This effect can be estimated using psychrometric charts. The largest volume expansion occurs with the greatest temperature and humidity difference 


$$
W H(-58)-W M-6 N-048 \text { Rev } 0
$$

across the course of the accident Assume the air in the pit is initially at $30 \mathrm{~F}$ and $15 \%$ relative humidity (l:.H). These are judged to be a conservatively low values as the pit air temperature and humidity would be moderated somewhat by heat transfir from the soil and the waste tank connected via the valve pit drain line. Conservative final values to assume for the pit air temperature and humidity ire $120 \mathrm{~F}$ and $100 \% \mathrm{R} . \mathrm{H} .120 \mathrm{~F}$ is the maximum expected waste temperature during transfers. Heat transfer through the walls and covers of the pit, ind evaporative cooling could be expected to keep the final, steady-state pit iir temperature below the assumed $120 \mathrm{~F}$ imit.

A psychrometric chart is included in Appendix E. From this chart, the specific volume of air at $30 \mathrm{~F}$ anc $15 \% \mathrm{R} . \mathrm{H}$. is about $12.35 \mathrm{ft}^{3} / 1 \mathrm{~b}$ of dry air. The specific volume at $120 \mathrm{~F}$ and $: 00 \% \mathrm{R} . \mathrm{H}$. is about $16.7 \mathrm{ft}^{3} / 1 \mathrm{~b}$ of dry air. The volume of air displaced by licuid aerosols is small in comparison to the total volume of the pit. This effect was therefore ignored. Dividing the final pit air specific volume by the initial pit air specific volume gives an estimated volume expansion of 0.3 ! pit volumes $[(16.7 / 12.35)-1]$.

Valve pits range in size. f typical sized DST valve pit is 24l-AW-A. The dimensions of this pit are $14^{\prime} \times 12^{\prime}$ by $6^{\prime} 7^{\prime \prime}$ deep, for a total volume of $1110 \mathrm{ft}^{3}$. The largest active valve pit (241-AP) has dimensions of $61^{\prime} \times 16^{\prime} \times$ $8^{\prime}$ deep, for a total volume of $7810 \mathrm{ft}^{3}\left(220 \mathrm{~m}^{3}\right)$. Although the temperature, humidity and aerosol concentratiors assumed in this analysis are judged to be more representative of what might happen in the nominal sized valve pit, the spray leak is assumed to occur in the larger valve pit and produce the same final conditions as in the nominal case. This is done to maximize the total air volume expelled. Using the largest pit volume gives a volumetric release (air expelled) of $77 \mathrm{~m}^{3}\left[(0.35)\left(22 \mathrm{~m}^{3}\right)\right]$. This release occurs during the initial stages of the accident.

\subsubsection{Air ExpuTsion due to Liquid Displacement}

The air expulsion rate due to liquid displacement is a function of the total leak rate through the crack, which is variable. Larger leaks are less efficient generators of aerosols but displace air from the pit at a higher rate. For the mitigated analysis, it is assumed that liquid spilling into the pit displaces air from the pit at a rate of $4.6 \mathrm{~m}^{3} / \mathrm{hr}$. This corresponds to a liquid flowrate of $76 \mathrm{~L} / \mathrm{min}(20 \mathrm{gpn})$. At this flowrate, the pit will be filled half full during the 24 hour duration of the accident. The piping in the pit will be submerged and aerosol production suppressed when the liquid reaches this level, so this flowrate maximizes the total volume of air expelled. Liquid flowrates larger than $20 \mathrm{gpm}$ will not be efficient generators of aerosols and do not lave to be considered.

\subsubsection{Aerosol Release Quantities}

Multiplying the air expulsior volume by the aerosol loading limit of 100 $\mathrm{mg} / \mathrm{m}^{3}$ gives the equivalent mass of tank waste released in the accident. This is converted to equivalent volume ising an estimated density for the waste of $1.4 \mathrm{~g} / \mathrm{cc}$. This density correspond; to the upper operating limit of the evaporator and is judged to be representative of waste containing 33 vol \% entrained solids.

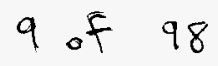




$$
W H C-50-W M-C N-048 \text { RevC }
$$

The release of aerosols fron the pit varies as a function of time. The release rate in the first hour is much higher than the release during the remainder of the accident, due to the volume expansion due to the initial temperature and humidity increase. The release of aerosols over the first hour of the accident is combination of both effects.

The equivalent volume of waste released over the first hour of the accident is estimated as follows:

$$
\begin{aligned}
Q(1 \mathrm{st} \mathrm{h}) & =\left[77 \mathrm{~m}^{3}+\left(4.6 \mathrm{~m}^{3}, \mathrm{~h}\right)(1 \mathrm{~h})\right]\left(100 \mathrm{mg} / \mathrm{m}^{3}\right)(1 \mathrm{~L} / 1.4 \mathrm{E} 6 \mathrm{mg}) \\
& =5.8 \mathrm{E}-3 \mathrm{~L}
\end{aligned}
$$

The equivalent volume of waste released between 1 and 12 hours (used to estimate onsite dose) is estimated as follows:

$$
\begin{aligned}
Q(1 \text { to } 12 \mathrm{~h}) & =\left(4.6 \mathrm{~m}^{3} / \mathrm{h}\right)(1: \mathrm{h})\left(100 \mathrm{mg} / \mathrm{m}^{3}\right)(1 \mathrm{~L} / 1.4 \mathrm{E} 6 \mathrm{mg}) \\
& =3.6 \mathrm{E}-3 \mathrm{~L}
\end{aligned}
$$

The equivalent volume of waste released over the time frame between 1 hour and 24 hours (used to estima:e portion of offsite dose) can be linearly scaled from the 1- to $12-h$ result

$$
Q(1 \text { to } 24 \mathrm{~h})=(3.6 \mathrm{E}-3 \mathrm{~L})(2.3 / 11)=7.5 \mathrm{E}-3 \mathrm{~L}
$$




\section{WHC-SC-WM-CN-OY8 REJ O}

\subsection{CONSEQUENCE ANALYSIS}

The aerosol release results in both radiological and toxicological exposures. The radiological and toxicological consequences are calculated for the unmitigated accident in Secticn 4.1. The radiological and toxicological consequences for the mitigated accident are calculated in Sections 4.2.

\subsection{UNMITIGATED ACCIDENT CONSEQUENCES}

The unmitigated accident cor sequence analysis is divided into two subsections. Radiological consequences are quantified in subsection 4.1.1 below. Toxicological consequences are calculated in subsection 4.1.2.

\subsubsection{Unmitigated Radiological Consequences}

The onsite and offsite doses are calculated in accordance with the methodology outlined in WHC-SD-WM-SARR-016 (1996) and WHC-SD-WM-SARR-037 (1996). An inhalation dose is calculated for the onsite receptor. The offsite receptor receives an inhalation dose and is also assumed to receive a 24 hour uptake ingestion dose.

The inhalation doses to the onsite and offsite receptors are calculated as follows:

$$
D_{i n h}=(Q)\left(X / Q^{\prime}\right)(B R)\left(U L D_{i n h}\right)
$$

The ingestion dose to the offsite receptor is calculated with the following equation:

$$
D_{\text {ing }}=(Q)\left(X / Q^{\prime}\right)\left(U \perp D_{\text {ing }}\right)
$$

Where,

$$
\begin{aligned}
& D_{\text {inh }}=\text { dose, in Sv (50-yr CEDE) } \\
& D_{\text {ing }}^{\text {inh }}=\text { dose, in Sv (50-yr C DDE) } \\
& Q^{\text {ing }}=\text { respirable release } 107 \text { ume over time period of concern, in } \\
& \text { equivalent } L \text { of vaste material } \\
& X / Q^{\prime}=\text { atmospheric dispersion coefficient, in } \mathrm{s} / \mathrm{m}^{3} \text {, from SARR-016 } \\
& \mathrm{BR}=\text { receptor breathing ate, in } \mathrm{m}^{3} / \mathrm{s} \\
& \mathrm{ULD}_{\text {inh }}=\text { inhalation unit } 1 \text { ite } \text { dose, in SV } / \frac{1}{3} \text {, from SARR-037 } \\
& U L D_{\text {ing }}^{\text {inh }} \text { = ingestion unit liter dose, in } \mathrm{Sv}-\mathrm{m}^{3} / \mathrm{s}-\mathrm{L} \text {, from SARR-037 }
\end{aligned}
$$

The release volumes (Q) over 12 and 24 hours are reported in Section 3.1 .2 . The acute and annual $X / Q^{\prime} s$ for the onsite and offsite receptor locations are summarized in SARR-0.6 and reproduced in Tables D-1 and D-2. $X / Q$ 's interpolated from the acute ind chronic $X / Q^{\prime} s$ for various time periods of interest in the TWRS accident arlalyses are calculated in Appendix $D$ and summarized in Table $D-3$. The active man's breathing rate (BR) is $3.3 E-4 \mathrm{~m}^{3} / \mathrm{s}$ (see SARR-016). This breathing rate applies to the onsite receptor during the entire duration of exposure. The nactive breathing rate is $1.5 \mathrm{E}-4 \mathrm{~m}^{3} / \mathrm{s}$. This breathing rate applies to the offsite receptor during an assumed 8 hours out of every 24 hours when the receptor is at rest. The $24-h$ average $B R$ for the offsite receptor is $2.7 \mathrm{E}-4 \mathrm{~m}^{3} / \mathrm{s}[(16 / 24)(3.3 \mathrm{E}-4)+(8 / 24)(1.5 \mathrm{E}-4)]$.

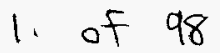




\section{WHC-SD-WM-CN-048 RevO}

The ULDs from SARR-037 for oth the inhalation and ingestion pathways, by waste type, are reproduced in lable 4-1. For this accident, the waste being sprayed is assumed to be colposed of a composite slurry of aging waste containing 33 vol $\%$ solids, 77 vo \% liquids. From Table $4-1$, the ULD ${ }_{\text {inh }}$ for aging waste solids is $1.7 \mathrm{E}+06 \mathrm{SV} / .$. The ULD $D_{\text {inh }}$ for aging waste liquids is $1.4 \mathrm{E} 03 \mathrm{SV} / \mathrm{L}$. The ULD for the composite slurry is thus $5.6 \mathrm{E}+05 \mathrm{SV} / \mathrm{L}$ $[(0.33)(1.7 \mathrm{E}+06)+(0.67)(1.4 \mathrm{E}+03 \mathrm{~Sv} / \mathrm{L})]$. Calçulating in the same manner, the aging waste composite slurry $\mathrm{ULD}_{\mathrm{irg}}$ is $2.7 \mathrm{~Sv}-\mathrm{m}^{3} / \mathrm{L}-\mathrm{s}[(0.33)(8.1)+$ $(0.67)(0.092)]$.

4.1.1.1 Onsite Receptor Dose. Fom Section 3.1.2, the 12 hour respirable release volume is $150 \mathrm{~L}$. From Talsle D-3 (in Appendix D), the 12 hour onsite $X / Q^{\prime}$ is $5.54 E-3 \mathrm{~s} / \mathrm{m}^{3}$. The inhalation ULD from above is $5.6 \mathrm{E}+5 \mathrm{SV} / \mathrm{L}$. Using the active breathing rate, the on:ite dose is:

$$
\begin{gathered}
\text { Dose (inh, on })=(150 \mathrm{~L})\left(5.5 \cdot \mathrm{E}-3 \mathrm{~s} / \mathrm{m}^{3}\right)\left(3.3 \mathrm{E}-4 \mathrm{~m}^{3} / \mathrm{s}\right)(5.6 \mathrm{E} 5 \mathrm{SV} / \mathrm{L}) \\
=150 \mathrm{SV}(1.50 \mathrm{E} \cdot . \cdot 4 \mathrm{rem}) .
\end{gathered}
$$

4.1.1.2 Offsite Receptor Dose. From Section 3.1.2, the 24 hour respirable release volume is $300 \mathrm{~L}$. From Table D-3 (Appendix D), the 24 hour offsite $X / Q^{\prime}$ is $4.62 \mathrm{E}-6 \mathrm{~s} / \mathrm{m}^{3}$. The inhalation ULD from above is $5.6 \mathrm{E}+5 \mathrm{SV} / \mathrm{L}$. Using the 24 hour average receptor rate the offsite inhalation dose is:

$$
\begin{aligned}
\text { Dose }(i n h, \text { off }) & =(300 \mathrm{~L})\left(4 .\left(i 2 \mathrm{E}-6 \mathrm{~s} / \mathrm{m}^{3}\right)\left(2.7 \mathrm{E}-4 \mathrm{~m}^{3} / \mathrm{s}\right)(5.6 \mathrm{E} 5 \mathrm{~Sv} / \mathrm{L})\right. \\
= & 0.21 \mathrm{SV} .
\end{aligned}
$$

Using the ingestion ULD from above, the offsite ingestion dose is:

$$
\begin{aligned}
\text { Dose (ing, off }) & =(300 \mathrm{~L})\left(4 .\left(.2 \mathrm{E}-6 \mathrm{~s} / \mathrm{m}^{3}\right)\left(2.7 \mathrm{SV}-\mathrm{m}^{3} / \mathrm{L}-\mathrm{s}\right)\right. \\
= & 3.7 \mathrm{E}-3 \mathrm{SV}
\end{aligned}
$$

The total offsite dose from both fathways is:

$$
\text { Dose (tota1, off) }=0.21 \text { Sv } 121 \text { rem) }
$$

The ingestion pathway added insigrificantly to the inhalation dose (within the significant digits of the calculation).

\subsubsection{Unmitigated Toxicological Exposures}

Onsite and offsite toxicolocical exposures are assessegusing the sumof-fractions methodology outiined in WHC-CM-SARR-011 (1998). Thable 4-2 gives the unit liter sum-of-fractions miltipliers for the various waste types, broken into liquids values and solids values. Note that the sum-of-fraction multipliers are dependent on accicent frequency.

For the waste type postulated to be released in this accident, a composite sum-of-fractions multiplier must be determined. The frequency category of the unmitigated accident is Anticipated ( $>1 \mathrm{E}-2$ events/yr). For DST solids (for toxicological assessments the DST values are used for aging waste), the onsite sum-of-fractions multiplier from Table 4-2 is $1.8 \mathrm{E}+04 \mathrm{~s} / \mathrm{L}$; the offsite value is $1.9 E+02 \mathrm{~s} / \mathrm{L}$. The onsite and offsite sum-of-fractions multiplier for DST liquids are $1.0 E+04 \mathrm{~s} / \mathrm{L}$ and $8.4 \mathrm{~s} / \mathrm{L}$, respectively. Based

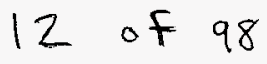




$$
\text { WHC-SD-WM-CN-048, RevO }
$$

on a solids content of 33 vol \%, the composite sum of fractions multiplier for the onsite and offsite receptors are:

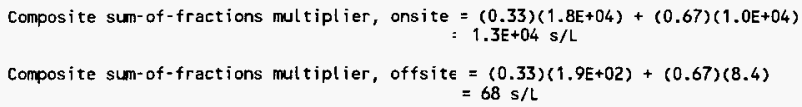

Toxicological exposure is assessed by multiplying the release rate by the sum-of-fractions multiplier. Products less than one are considered to indicate acceptable risk (i.e., indicate exposures below evaluation guidelines).

From Section 3.1.2, the resuirable aerosol release rate in the unmitigated accident was found to be $0.21 \mathrm{~L} / \mathrm{min}$, or $3.5 \mathrm{E}-3 \mathrm{~L} / \mathrm{s}$. Multiplying by the onsite sum-of-fractions multiplier gives a product of $46[(3.5 \mathrm{E}-3$ $\mathrm{L} / \mathrm{s})(1.3 \mathrm{E} 4 \mathrm{~s} / \mathrm{L})]$. The offsite product is $0.24[(3.5 \mathrm{E}-3 \mathrm{~L} / \mathrm{s})(68)]$.

\subsection{MITIGATED ACCIDENT CONSEQUEN:ES}

\subsubsection{Mitigated Radiological Consequences}

The mitigated dose conseque ces are calculated using the same dose model discussed for the unmitigated accident in Section 4.1.1. However, since the release varies with time, a dose is calculated for the first hour of the release and added to the dose fron the next 11 hours to estimate the onsite receptor dose. To estimate the offsite receptor dose, the $1-h$ dose is added to the 1- to 24-h dose. The acut $3,1-h, X / Q^{\prime}$ is used to estimate the dose during the first hour of the releise. The appropriate extended duration $X / Q$ 's from Table D-1 are used to estima:e the doses following the first hour of the accident.

4.2.1.1 Onsite Receptor Dose. The acute $X / Q^{\prime}$ for the onsite receptor from Appendix $D$ is $3.41 \mathrm{E}-2 \mathrm{~s} / \mathrm{m}^{3}$. From Section $3.2 .3, Q(1 \mathrm{st} \mathrm{hr})=5.7 \mathrm{E}-3 \mathrm{~L}$. The waste composite inhalation ULD from 4.1 .1 is $5.6 E+5 \mathrm{SV} / \mathrm{L}$. The dose to the onsite receptor during the first nour is

$$
\begin{aligned}
D(\text { inh, on }, 1 h) & =(5.7 E-3 \mathrm{~L})\left(3.41 \mathrm{E}-2 \mathrm{~s} / \mathrm{m}^{3}\right)\left(3.3 \mathrm{E}-4 \mathrm{~m}^{3} / \mathrm{s}\right)(5.6 \mathrm{E}+5 \mathrm{~Sv} / \mathrm{L}) \\
& =3.6 \mathrm{E}-2 \mathrm{SV} .
\end{aligned}
$$

The release during the 1- to 12- I time frame, from Section 3.2 .3 , is $3.6 E-3$ $L$. From Table $D-1$, the 11 hour onsite $X / Q^{\prime}$ is $5.74 \mathrm{E}-3 \mathrm{~s} / \mathrm{m}^{3}$. The dose during this timeframe is therefore

$$
\begin{aligned}
\mathrm{D}(\mathrm{inh}, \mathrm{on}, 1-12 \mathrm{~h}) & =(3.6 \mathrm{E}-3 \mathrm{~L})\left(5.74 \mathrm{E}-3 \mathrm{~s} / \mathrm{m}^{3}\right)\left(3.3 \mathrm{E}-4 \mathrm{~m}^{3} / \mathrm{s}\right)(5.6 \mathrm{E} 5 \mathrm{~Sv} / \mathrm{L}) \\
& =3.8 \mathrm{E}-3 \mathrm{SV} .
\end{aligned}
$$

The total onsite dose is

$$
D(\text { inh, on, tot })=4.0 \mathrm{E}-2 \mathrm{SV}(1.0 \mathrm{rem})
$$




$$
W H C-S D-W M-C N-048 \text { Rev }
$$

4.2.1.2 Offsite Receptor Dose. The acute $X / Q^{\prime}$ for the offsite receptor from Appendix $D$ is $2.83 \mathrm{E}-5 \mathrm{~s} / \mathrm{m}^{3}$. From Section 3.2.3, $Q$ (1st hr) $=5.7 \mathrm{E}-3 \mathrm{~L}$. The waste composite inhalation ULD from Section 4.1 .1 is $5.6 E+5 \mathrm{SV} / \mathrm{L}$. The ingestion ULD is $2.7 \mathrm{~Sv}-\mathrm{m}^{3} / \mathrm{L}-\mathrm{s}$. The inhalation and ingestion doses to the offsite receptor during the first hour are therefore:

$$
\begin{aligned}
D(\text { inh, off, lh }) & =(5.8 E-3 \mathrm{~L})\left(? .83 \mathrm{E}-5 \mathrm{~s} / \mathrm{m}^{3}\right)\left(3.3 \mathrm{E}-4 \mathrm{~m}^{3} / \mathrm{s}\right)(5.6 \mathrm{E}+5 \mathrm{~Sv} / \mathrm{L}) \\
= & 3.0 \mathrm{E}-5 \mathrm{~Sv} . \\
D(\text { ing, off, lh }) & =(5.8 \mathrm{E}-3 \mathrm{~L})\left(? .83 \mathrm{E}-5 \mathrm{~s} / \mathrm{m}^{3}\right)\left(2.7 \mathrm{~Sv}-\mathrm{m}^{3} / \mathrm{L}-\mathrm{s}\right) \\
= & 4.4 \mathrm{E}-7 \mathrm{~Sv}
\end{aligned}
$$

The release during the 1- to 24- , time frame, from Section 3.2 .3 , is $7.5 \mathrm{E}-3$ $L$. From Table D-3, the 23 hour o fsite $X / Q^{\prime}$ is $4.74 \mathrm{E}-06 \mathrm{~s} / \mathrm{m}^{3}$. The doses during this timeframe are therefo'e

$$
\begin{aligned}
D(\text { inh, off, } 1-24 \mathrm{~h}) & =(7.5 \mathrm{E}-3 \mathrm{~L})\left(4.74 \mathrm{E}-6 \mathrm{~s} / \mathrm{m}^{3}\right)\left(3.3 \mathrm{E}-4 \mathrm{~m}^{3} / \mathrm{s}\right)(5.6 \mathrm{E} 5 \mathrm{~Sv} / \mathrm{L}) \\
& =6.6 \mathrm{E}-6 \mathrm{SV} .
\end{aligned}
$$

Note: to simplify calculation, the above equation conservatively ignores the fall off in breathing rite during the period of time the receptor is at rest.

$$
\begin{aligned}
D(\text { ing }, \text { off }, 1-24 \mathrm{~h}) & =(7.5 \mathrm{E}-3 \mathrm{~L})\left(4.74 \mathrm{E}-6 \mathrm{~s} / \mathrm{m}^{3}\right)\left(2.7 \mathrm{SV}-\mathrm{m}^{3} / \mathrm{L}-\mathrm{s}\right) \\
= & 9.6 \mathrm{E}-8 \mathrm{SV}
\end{aligned}
$$

The total offsite dose from both pathways, over both time increments, is:

$$
\text { Dose (total, off) }=3.7 E-5 \mathrm{~Sv}(3.7 \mathrm{E}-3 \mathrm{rem})
$$

\subsubsection{Mitigated Toxicological Exposures}

Toxicological exposures are assessed by looking at the peak concentration at the receptor locition, as opposed to determining a time integrated exposure as in radiolocical dose calculations. The toxicological sum-of-fractions values are based on one hour exposures 1 imits (e.g., ERPGs). It is generally interpreted that the peak concentration values to compare against the guidelines should be $b$ ased on peak, 15 minute average concentrations.

The maximum aerosol release rate from the pit occurs during the initial temperature and humidity induced expansion, From Section 3.2.3, the volume of air expelled during this expansior is $77 \mathrm{~m}^{3}$. Assume this entire volume comes out during the first 15 minutes of the accident. Also add in the volume of air displaced due to liquid spilling to the floor at a rate of $76 \mathrm{~L} / \mathrm{min}$ (20 gpm). The aerosol release during the first 15 minutes of the accident can be calculated in the same manner to the one hour release rate calculated in Section 3.2.3:

$$
\begin{aligned}
Q(1 s t 15 \mathrm{~min}) & =\left[77 \mathrm{~m}^{3}+\left(0.076 \mathrm{~m}^{3}, \min \right)(15 \mathrm{~min})\right]\left(100 \mathrm{mg} / \mathrm{m}^{3}\right)(1 \mathrm{~L} / 1.4 \mathrm{E} 6 \mathrm{mg}) \\
& =5.6 \mathrm{E}-3 \mathrm{~L}
\end{aligned}
$$




$$
\text { WHC-:DD-WM-CN-048 RevO }
$$

Dividing by 15 gives the 15 minute average release rate, or $3.7 \mathrm{E}-4 \mathrm{~L} / \mathrm{min}$, or $6.2 \mathrm{E}-6 \mathrm{~L} / \mathrm{s}$. Using the composite sum-of-fractions multipliers from Section 4.1.2, the onsite and offsite receptor exposures, for the mitigated accident, are:

$$
\text { Onsite sum-of-fractions }=(€ .2 E-6 \mathrm{~L} / \mathrm{s})(1.3 \mathrm{E} 4 \mathrm{~s} / \mathrm{L})=8.1 \mathrm{E}-2
$$

Offsite sum-of-fractions $=(6.2 \mathrm{E}-6 \mathrm{~L} / \mathrm{s})(68 \mathrm{~s} / \mathrm{L})=4.2 \mathrm{E}-4$ 
WHC - SD-WM-CN-O48, Rev 0

\subsection{COMPARISON TO EVALUATION GUIDELINES}

The radiological doses and oxicological exposures for the unmitigated and mitigated accidents are summa ized and compared against the TWRS evaluation guidelines (EGs) in Table 5-1.

The unmitigated accident raliological doses are well above both the offsite and onsite evaluation guilelines corresponding to the frequency category of the accident (Anticipited). The unmitigated offsite dose exceeds the EG for the Unlikely category is well. The unmitigated onsite dose is well above the EG for the Extremely Un ikely category. The offsite dose from the mitigated spray leak is shown to be acceptable. The onsite dose for the mitigated accident, however, is s ightly above the EG for the anticipated category.

The toxicological sum-of-frictions is well over one for the unmitigated accident at the onsite receptor lication. The toxicological consequences therefore exceed the onsite evaluation guidelines. The offsite toxicological consequences for the unmitigated iccident are below evaluation guidelines. With the cover blocks on the toxicological sum-of-fractions is shown be well below one and hence well below the evaluation guidelines for both the onsite and offsite receptors. 
$W H C-50-W M-C N-048$, Rev $O$

\section{0 EXTRAPOLATION TO OTHER RELEVANT CASES}

The valve pit spray leak involving aging waste was selected as the bounding, representative accident of its type. Spray leaks, however, can occur at a variety of locations throughout the tank farm transfer systems. other process pits can experience leaks at different pressures, and with different types of waste than the representative case analyzed above. Three cases are discussed specifically in this section, to examine the conservatisms in using the aging waste spray leak as the representative case: 1) a spray leak from a valve pit involving CST waste, and 2) a spray leak inside an SST pump pit (during saltwell pumping), and 3) a spray leak inside a DCRT pump pit. A11 three cases examined occur inside process pits. The process pit cases are adequate to represent the other potential leakage sites (e.g., sprays inside cleanout boxes, sprays from encasement risers, sprays inside diversion boxes) because the unmitigated consequences in all cases would be expected to be similar. In all the unmitigated cases the spray emits directly to the atmosphere.

The radiological doses are shown in Section 5 to be limiting (i.e., the onsite radiation EGs are exceeded quicker than the onsite toxicological EGs). A comparison of radiation doses is therefore sufficient to draw conclusions about spray leaks at the additional spray leak sites. The following three sections develop the source terms and doses associated with the three additional spray leak sites. The doses are compared against the representative case and EGs in iection 6.4.

\subsection{SPRAY LEAK OF DST WASTE INSI JE VALVE PIT}

The potential leak dimensious in the DST case are the same as in the aging waste case. The gross wast a properties (e.g., viscosity, density, solids content) can be assumed to be similar in both cases. Assuming a 2 inch long crack in a 2 inch schedule 4) pipe and a $300 \mathrm{psig}$ maximum pressure, the optimum respirable aerosol releas? rate is the same in the DST case as in the aging waste case. The doses in $t$ je DST case can therefore be estimated simply by multiplying the aging waste results by the ratio of the DST waste composite ULD to the aging waste composite JLD.

For a DST waste stream containing 33 vol \% solids, the composite inhalation and ingestion ULDs, using the values from Table 4-1 are:

$$
\begin{aligned}
& \text { DST composite ULD inp }=(0.33)(5.3 \mathrm{E} 5 \mathrm{~Sv} / \mathrm{L})+(0.67)(6.1 \mathrm{E} 3 \mathrm{SV} / \mathrm{L}) \\
& =1.8 \mathrm{E} 5 \mathrm{SV} / \text {. } \\
& \text { DST composite } \begin{aligned}
U L D_{\text {ing }} & =(0.33)(0.48 \mathrm{~Sv}-\mathrm{m} / \mathrm{L}-\mathrm{s})+(0.67)(0.068 \mathrm{~Sv}-\mathrm{m} / \mathrm{L}-\mathrm{s}) \\
& =0.20 \mathrm{~Sv}-\mathrm{m} / \mathrm{L}-\mathrm{s}
\end{aligned}
\end{aligned}
$$

These ULDs compare to $5.6 E 5 \mathrm{~Sv} / \mathrm{L}$ and $2.7 \mathrm{~Sv}-\mathrm{m}^{3} / \mathrm{L}-\mathrm{s}$, respectively for the aging waste case.

\subsubsection{Unmitigated Accident Doses}

Ratioing the doses reported in Section 4.1.1 for the unmitigated scenario gives the following resu ts: 


$$
W H C-S D-W M-C N-048, \operatorname{Rev} \theta
$$

Onsite Dose

$\begin{aligned} D(\text { inh, on }) & =(150 \mathrm{SV})(1.8 \mathrm{ES} \mathrm{SV} / \mathrm{L}) /(5.6 \mathrm{E5} \mathrm{SV} / \mathrm{L}) \\ = & 48 \mathrm{SV}(4800 \mathrm{rem})\end{aligned}$

offsite Dose

$$
\begin{aligned}
D(\text { inh, off }) & =(0.21)(1.8 \mathrm{E} 5 \mathrm{SV} / \mathrm{L}) /(5.6 \mathrm{E} 5 \mathrm{SV} / \mathrm{L}) \\
= & 6.8 \mathrm{E}-2 \mathrm{SV}(6.8 \mathrm{rm}) \\
D(\text { ing, off }) & =(3.7 \mathrm{E}-3 \mathrm{~Sv})\left(0.20 \mathrm{~Sv}-\mathrm{m}^{3} / \mathrm{L}-\mathrm{s}\right) /\left(2.7 \mathrm{~Sv}-\mathrm{m}^{3} / \mathrm{L}-\mathrm{s}\right) \\
= & 2.7 \mathrm{E}-4 \mathrm{SV}(2.7 \mathrm{E}-2 \mathrm{rem}) \\
D(\text { tot }, \text { off }) & =6.8 \mathrm{E}-2 \mathrm{~Sv}(6.8 \mathrm{rem})
\end{aligned}
$$

\subsubsection{Mitigated Accident Doses} results:

Ratioing the doses reported in Section 4.1 .2 gives the following

Onsite Dose

$$
\begin{aligned}
D(\text { inh, on }, 1 \mathrm{~h}) & =(3.6 \mathrm{E}-2 \mathrm{SV})(\mathrm{l} .8 \mathrm{E} 5 \mathrm{SV} / \mathrm{L}) /(5.6 \mathrm{E} 5 \mathrm{SV} / \mathrm{L}) \\
= & 1.2 \mathrm{E}-2 \mathrm{SV} \\
\mathrm{D}(\text { inh, on, } 1-12 \mathrm{~h}) & =(3.8 \mathrm{E}-3 \mathrm{~S} /)(1.8 \mathrm{E} 5 \mathrm{~Sv} / \mathrm{L}) /(5.6 \mathrm{E} 5 \mathrm{~Sv} / \mathrm{L}) \\
= & 1.2 \mathrm{E}-3 \mathrm{SV}
\end{aligned}
$$

The total onsite dose is:

$$
D(\text { tot, on })=1.3 \mathrm{E}-2 \mathrm{~Sv}(1.3 \mathrm{em})
$$

Offsite Dose

$$
\begin{aligned}
& D(\text { inh, off, } 1 \mathrm{~h})=(3 \mathrm{E}-5 \mathrm{~Sv})(18 \mathrm{E} 5 \mathrm{~Sv} / \mathrm{L}) /(5.6 \mathrm{E} 5 \mathrm{~Sv} / \mathrm{L}) \\
& =9.6 \mathrm{E}-6 \mathrm{~Sv}(9.1 \mathrm{iE}-4 \mathrm{rem}) \\
& \left.D(\text { ing, off }, \mathrm{lh})=(4.4 \mathrm{E}-7 \mathrm{~Sv}) 0.20 \mathrm{~Sv}-\mathrm{m}^{3} / \mathrm{L}-\mathrm{s}\right) /\left(2.7 \mathrm{~Sv}-\mathrm{m}^{3} / \mathrm{L}-\mathrm{s}\right) \\
& =3.3 \mathrm{E}-8 \mathrm{SV} \text { (3..iE-6 rem) } \\
& D(\text { inh, off }, 1-24 h)=(6.7 E-6 \mathrm{iv})(1.8 \mathrm{E} 5 \mathrm{~Sv} / \mathrm{L}) /(5.6 \mathrm{E5} \mathrm{Sv} / \mathrm{L}) \\
& =2.1 \mathrm{E}-6 \mathrm{SV}(2 . \mathrm{E}-4 \mathrm{rem}) \\
& D \text { (ing, off, } 1-24 \mathrm{~h})=(9.7 \mathrm{E}-8 \mathrm{iv})\left(0.20 \mathrm{~Sv}-\mathrm{m}^{3} / \mathrm{L}-\mathrm{s}\right) /\left(2.7 \mathrm{~Sv}-\mathrm{m}^{3} / \mathrm{L}-\mathrm{s}\right) \\
& =7.2 \mathrm{E}-9 \mathrm{SV} \text { (7. E-7 rem) }
\end{aligned}
$$

The total offsite dose is

$$
D(\text { off }, \text { tot })=1.2 \mathrm{E}-5 \mathrm{SV}(1.2 \mathrm{t}-3 \mathrm{rem})
$$

The ingestion doses are insignificant in comparison to the inhalation doses for this case.

\subsection{SPRAY LEAK INSIDE SST PUMP PIT}




$$
W H C-S D-W N-C N-048 \text {, Rev } O
$$

Surface liquids and saltwel liquor are pumped out of SSTs usually using saltwell jet pumps. In some cast:s, submersible pumps are used. The pump curves for each type are included in Appendix B. The SST 1 iquids (which will include some entrained solids) ar: usually transferred to a DCRT, where eventualiy the waste is batch transferred to DST. The pump curves in Appendix $B$ show that the pressure potentia in the SST transfer lines between SST and DST pump pits is much smaller thall for aging waste or DST transfers.

In the saltwell jet pump sy:tem, waste is recirculated in a loop of piping running between the tank and the SST pump pit. A diaphragm operated valve (DOV) opens and shuts as required to pump the tank without letting the saltwe11 run dry, which would cav tate the pump. Pressures downstream of the DOV valve are lower than pressure:; in the recirculation loop due to frictional losses across the DOV.

The saltwell pump recircula:ion loop has waste under higher pressure than the submersible pump system al though the submersible pump pumps at much higher flowrates). The saltwell :ystem therefore poses the greatest risk for a spray leak inside an SST pump p t. A spray leak involving a saltwell system piping is analyzed as the boundin! case.

\subsubsection{Source Term Analysis}

6.2.1.1 Unmitigated Accident Source Term. From Appendices B, the maximum head in the saltwell recirculatiol system is $160 \mathrm{ft}$. The pressure falls off to $100 \mathrm{ft}$ for a flowrate through the DOV of $4 \mathrm{gpm}$. The flowrate through the leak in this case is likely to ha'e a significant effect on the pressure in the line so an iterative approach is required to determine the optimum respirable aerosol release rate. The process is as follows: 1) guess waste pressure, 2) use SPRAY to determilie the optimum crack size that produces the maximum flowrate of respirable siied aerosols, 3) from total flowrate predicted by SPRAY, check the pumf curve and compare pressure corresponding to the total flowrate predicted by SfRAY to initial guess, 4) iterate until the guess pressure and pump curve pres sure are comparable.

Step 1. Assuming an SpG of 1.4 (corresponding to slurry containing 33 vol \% solids) as in the aging waste and DST cases, the maximum pressure in the saltwell recirculation loop range: from (160 ft) (atm/33.9 ft of $\left.\mathrm{H}_{2} 0\right)(1.4)(14.7$ $\mathrm{psi} / \mathrm{atm})=97 \mathrm{psi}$ at $0 \mathrm{gpm}$ to 60 isi $[(97 \mathrm{psi})(100) /(160)]$ at $4 \mathrm{gpm}$. Assume an initial pressure of 85 psi.

Step 2. The saltwell piping is 1 in., schedule 40 piping. Use the same SPRAY input parameter assumptions as in the aging waste spray leak. This gives a pipe thickness of $0.133 \mathrm{ir}$, an assumed waste $\mathrm{SpG}$ of 1.4 , a respirable aerosol size of 15 um, and a waste viscosity of $1 \mathrm{cps}$. The maximum crack length was assumed, as in the agirg waste case, to be 2 inches.

The SPRAY leak input deck ard results are included in Appendix $C$ as Case 2. The optimum crack width was fcund to be $4.16 \mathrm{E}-3$ in $(1.06 \mathrm{E}-3 \mathrm{~cm})$. The total flowrate through the optimun sized leak was found to be $1.21 \mathrm{gpm}$, and the respirable flowrate was found to be $7.65 \mathrm{E}-3 \mathrm{gpm}$, or $4.83 \mathrm{E}-4 \mathrm{~L} / \mathrm{s}$. The respirable fraction is $6.3 \mathrm{E}-3$. Over a $12-\mathrm{h}$ period this respirable aerosol release rate gives a volumetric release of $21 \mathrm{~L}$. Over 24 hours, the volumetric release is $42 \mathrm{~L}$. 


\section{$W H C-5 D-W M-C N-048$ Rev 0}

Step 3. The total flowrate predicted by SPRAY of $1.21 \mathrm{gpm}$ gives an estimated head from the saltwell pump curve in Appendix B of about $140 \mathrm{ft}$. Converting to pressure, using an SpG of 1.4 , gives $85 \mathrm{psi}$. The guess pressure and predicted pressure match and hence no further iteration is required.

6.2.1.2 Mitigated Accident Source Term. With the cover blocks on, the aerosol release from the pit would be limited. Assume a maximum aerosol loading limit for the air expelled from the pit of $100 \mathrm{mg} / \mathrm{m}^{3}$, as was done in the aging waste case. The potential mechanisms driving air from the SST pump pit vary a little bit from those in the aging waste valve pit leak. There is still in this case an initial exfansion of air caused potentially by a temperature and humidity increase in the pit air. Unlike in the representative valve pit case analyzed above, most SSTs are not actively ventilated. Hence, there is no craw on the pit through the drain line (assuming it's open) to limit the release of aerosols after the initial volume expansion. With an open drain, there is the potential for the SST to breathe out through the pump pit drain, expelling contaminated air to the atmosphere through the cover block gaps and penetrations. This breathing out or natural ventilation mechanism can be caused by heat load in the tank and pit (i.e., chimney effect), wind effects, and barometric pressure changes.

The volumetric air exchanges from the pump pit due to both mechanisms are quantified in the following subsections.

Air Expulsion Due to Temper ature and Humidity Increase. The initial temperature and humidity increase could be expected to produce a similar volumetric exchange as in the representative case. In Section 3.2.1, this exchange is predicted to be 0.35 pit volumes.

SST pump pits vary in size and shape. Some are round caissons; some are rectangular concrete pits. BY farm has several tanks scheduled to be saltwell pumped. Pump pits 241-BYR-01A, C4A, 11A, and 12A in this farm are all 17.5' long by $15.5^{\prime}$ wide. All of these are expected to be between 5 and $6 \mathrm{ft}$ deep, based on soil cover shown in the drawings for the SSTs. Assuming a depth of 6 $\mathrm{ft}$ gives a total volume for the typical BY farm pump pits of $1630 \mathrm{ft}^{3}$.

The total volume of air expelled from the pit due to this mechanism is
$570 \mathrm{ft}^{3}[(1630)(0.35)]$, or $16.1 \mathrm{~m}^{\prime}$.

Air Expulsion Due to Natural Breathing. The natural ventilation rate is difficult to quantify for the pump pit and the connected SST. No tracer studies have been performed to measure the natural ventilation rates in passively ventilated tanks or the potential leakage rate from a pit in postulated accidents such as a spray leak.

A conservative estimate for the pit breathing rate is $5 \mathrm{cfm}$, or 8.5 $\mathrm{m}^{3} / \mathrm{h}$. This conservative estimate comes from computer modelling results for the cascade SSTs C-101, C-102 and C-103, reported in WHC-CM-WM-ER-127 (1991). The $5 \mathrm{cfm}$ value is conservative because it corresponds to the estimated total outleakage (both filtered and not filtered) predicted for the three tank series. Tanks $\mathrm{C}-101$ and $\mathrm{C}-102$ were predicted in the reference to have only inleakage. Tank $\mathrm{C}-103$ was predicted to breathe out through both the HEPA filtered, passive ventilation patr and to have fugitive emissions out other unfiltered paths in the tank. The outleakage through an individual pit would 


$$
\text { WHC-SO-WM-CN-O48 Rev } 0
$$

not be expected to be as high as uredicted for all paths for the entire tank. The pump pit in this study has an estimated volume of $1630 \mathrm{ft}^{3}$ (see discussion below). The $5 \mathrm{cfm}$ flowrate therefore corresponds to a volumetric exchange rate for the pit of $0.2 \mathrm{~V} / \mathrm{h}\left[\left(5 \mathrm{cfm} / 1630 \mathrm{ft}^{3}\right)(60 \mathrm{~min} / \mathrm{h})\right]$. Compare this to rule of thumb values for interior rooms in buildings and closed basements in one story homes reported in the literature to range from $0.1 \mathrm{~V} / \mathrm{h}$ to $0.4 \mathrm{~V} / \mathrm{h}$ (see ASHRAE 1977 and Socolow 1994).

The natural ventilation rat $\geq$ leads to a greater release than would occur if it was assumed the pit drain was plugged, as was done in the representative accident case. The assumed natural ventilation rate leads to $4.8 \mathrm{pit}$ volume exchanges over the 24-h duration of the accident, compared with one-half a volume exchange (assuming pipes bacome submerged when pit is half full) that could occur with a closed drain.

Aerosol Release Quantities. Over the first hour of the accident, the pit breathes $16.1 \mathrm{~m}^{3}$ of air due to the initial air expansion and $8.5 \mathrm{~m}^{3}$ of air due to natural ventilation. Assuining an airborne aerosol $1 \mathrm{imit}$ of $100 \mathrm{mg} / \mathrm{m}^{3}$, and converting using an assumed wiste $\mathrm{SpG}$ of 1.4, as was done in the aging waste spray leak analysis, gives 1 l-h aerosol release of

$$
\begin{aligned}
Q(1 \text { st hour }) & =\left(16.1 \mathrm{~m}^{3}+8 . ! \mathrm{m}^{3}\right)\left(100 \mathrm{mg} / \mathrm{m}^{3}\right)(1 \mathrm{~L} / 1.4 \mathrm{E} 6 \mathrm{mg}) \\
= & 1.8 \mathrm{E}-3 \mathrm{~L}
\end{aligned}
$$

The aerosol released over the 1 to 12 hour time frame is

$$
\begin{aligned}
\mathrm{Q}(1-12 \mathrm{~h}) & =\left(8.5 \mathrm{~m}^{3} / \mathrm{h}\right)(11 \mathrm{~h})\left(100 \mathrm{mg} / \mathrm{m}^{3}\right)(1 \mathrm{~L} / 1.4 \mathrm{E} 6 \mathrm{mg}) \\
= & 6.7 \mathrm{E}-3 \mathrm{~L}
\end{aligned}
$$

The aerosol released over the 1 to 24 hour time period is

$$
\begin{aligned}
Q(1-24 h) & =\left(8.5 \mathrm{~m}^{3} / \mathrm{h}\right)(23 \mathrm{~h})\left(100 \mathrm{mg} / \mathrm{m}^{3}\right)(1 \mathrm{~L} / 1.4 \mathrm{E} 6 \mathrm{mg}) \\
= & 1.4 \mathrm{E}-2 \mathrm{~L}
\end{aligned}
$$

\subsubsection{Consequence Analys is}

6.2.2.1 Unmitigated Accident Dose:. For this case, the waste inventory is assumed to be composed of 33 vol; SST solids, 67 vol \% SST 1iquids. The composite inhalation and ingestior ULDs for this waste mixture, using the values from Table 4-1, are as fol ows:

$$
\begin{aligned}
\mathrm{ULD}_{\text {inh }} & =(0.33)(2.2 \mathrm{E} 5 \mathrm{SV} / \mathrm{L}) \cdots(0.67)(1.1 \mathrm{E} 4 \mathrm{SV} / \mathrm{L}) \\
& =8.0 \mathrm{E} 4 \mathrm{SV} / \mathrm{L} \\
\mathrm{ULD}_{\text {ing }} & =(0.33)\left(4.1 \mathrm{SV}-\mathrm{m}^{3} / \mathrm{L}-\mathrm{s}\right)+(0.67)\left(0.052 \mathrm{SV}-\mathrm{m}^{3} / \mathrm{L}-\mathrm{s}\right) \\
& =1.4 \mathrm{~Sv}-\mathrm{m}^{\frac{3}{3}} / \mathrm{L}-\mathrm{s}
\end{aligned}
$$

Onsite Dose. From Section 6.2.1.1, the respirable aerosol release rate is $6.5 \mathrm{E}-4 \mathrm{~L} / \mathrm{s}$. Over a 12 hour period, the volumetric release is $28 \mathrm{~L}$. The onsite $12 \mathrm{~h} \mathrm{X} / \mathrm{Q}^{\prime}$ is $5.54 \mathrm{E}-3 \mathrm{~s} / \mathrm{m}^{3}$ (Table D-3). Using the active breathing rate, the onsite receptor dose is

$$
\begin{aligned}
\text { Dose }(\text { inh, on }) & =(21 \mathrm{~L})\left(5.54 \mathrm{E}-3 \mathrm{~s} / \mathrm{m}^{3}\right)\left(3.3 \mathrm{E}-4 \mathrm{~m}^{3} / \mathrm{s}\right)(8.0 \mathrm{E} 4 \mathrm{SV} / \mathrm{L}) \\
= & 3.1 \mathrm{SV}(31 \mathrm{rEm}) .
\end{aligned}
$$




$$
\text { WHC-SD-INM-CN-OY8 REU O }
$$

Offsite Dose. From Section 6.2.1.1, the 24 hour respirable release volume is $56 \mathrm{~L}$. From Table D-3 (tppendix D), the 24 hour offsite $X / Q^{\prime}$ is $4.62 \mathrm{E}-6 \mathrm{~s} / \mathrm{m}^{3}$. Using the 24 hour iverage receptor rate, the offsite inhalation dose is:

$$
\begin{aligned}
\text { Dose }(\text { inh, off }) & =(42 \mathrm{~L})\left(4.6 ? \mathrm{E}-6 \mathrm{~s} / \mathrm{m}^{3}\right)\left(2.7 \mathrm{E}-4 \mathrm{~m}^{3} / \mathrm{s}\right)(8.0 \mathrm{E} 4 \mathrm{~Sv} / \mathrm{L}) \\
= & 4.2 \mathrm{E}-3 \mathrm{SV} .
\end{aligned}
$$

Using the ingestion ULD from abovs, the offsite ingestion dose is:

$$
\begin{aligned}
\text { Dose (ing, off) } & =(42 \mathrm{~L})\left(4.6 \mathrm{JE}-6 \mathrm{~s} / \mathrm{m}^{3}\right)\left(1.4 \mathrm{~Sv}-\mathrm{m}^{3} / \mathrm{L}-\mathrm{s}\right) \\
= & 2.7 \mathrm{E}-4 \mathrm{~Sv}
\end{aligned}
$$

The total offsite dose from both sathways is:

$$
\text { Dose(total, off) }=4.5 \mathrm{E}-3 \mathrm{~s},(0.45 \mathrm{rem})
$$

\subsubsection{Mitigated Accident Doses}

Onsite Dose. The acute $X / Q$ for the onsite receptor from Appendix $D$ is $3.41 \mathrm{E}-2 \mathrm{~s} / \mathrm{m}^{3}$. From Section 6.2.1.2, $\mathrm{Q}(1 \mathrm{st} \mathrm{hr})=1.8 \mathrm{E}-3 \mathrm{~L}$. The dose to the onsite receptor during the first hour is

$$
\begin{aligned}
D(\text { inh, on, } 1 \mathrm{~h}) & =(1.8 \mathrm{E}-3 \mathrm{~L})\left(34 \mathrm{lE}-2 \mathrm{~s} / \mathrm{m}^{3}\right)\left(3.3 \mathrm{E}-4 \mathrm{~m}^{3} / \mathrm{s}\right)(8.0 \mathrm{E} 4 \mathrm{~Sv} / \mathrm{L}) \\
& =1.6 \mathrm{E}-3 \mathrm{SV} .
\end{aligned}
$$

The release during the 1 - to 12 - li time frame, from Section 6.2.1.2, is $6.7 \mathrm{E}-3$ $L$. From Table $D-1$, the 11 hour ollsite $X / Q^{\prime}$ is $5.74 E-3 \mathrm{~s} / \mathrm{m}^{3}$. The dose during this timeframe is therefore

$$
\begin{aligned}
D(\text { inh, on, } 1-12 & h)=(6.7 \mathrm{E}-3 \\
= & 1.0 \mathrm{E}-3 \mathrm{SV} .
\end{aligned}
$$

The total onsite dose is

$$
D(\text { inh, on, tot })=2.6 \mathrm{E}-3 \mathrm{SV}((.26 \mathrm{rem})
$$

Offsite Receptor Dose. The acute $X / Q^{\prime}$ for the offsite receptor from Appendix D is $2.83 \mathrm{E}-5 \mathrm{~s} / \mathrm{m}^{3}$. From Section 6.2.1.2, $Q(1 \mathrm{st} \mathrm{hr})=1.8 \mathrm{E}-3 \mathrm{~L}$. The inhalation and ingestion doses to the offsite receptor during the first hour are therefore:

$$
\begin{aligned}
D(\text { inh, off, lh }) & =(1.8 \mathrm{E}-3 \mathrm{~L})\left(\mathrm{c} .83 \mathrm{E}-5 \mathrm{~s} / \mathrm{m}^{3}\right)\left(3.3 \mathrm{E}-4 \mathrm{~m}^{3} / \mathrm{s}\right)(8.0 \mathrm{E}+4 \mathrm{~Sv} / \mathrm{L}) \\
= & 1.3 \mathrm{E}-6 \mathrm{~Sv} . \\
\mathrm{D}(\text { ing, off, lh }) & =(1.8 \mathrm{E}-3 \mathrm{~L})\left(\mathrm{c} .83 \mathrm{E}-5 \mathrm{~s} / \mathrm{m}^{3}\right)\left(1.4 \mathrm{~Sv}-\mathrm{m}^{3} / \mathrm{L}-\mathrm{s}\right) \\
= & 7.1 \mathrm{E}-8 \mathrm{~Sv}
\end{aligned}
$$

The release during the 1 - to $24-r$ time frame, from Section 6.2 .1 .2 , is $1.4 \mathrm{E}-2$ $L$. From Table $D-1$, the 23 hour offsite $X / Q^{\prime}$ is $4.74 \mathrm{E}-06 \mathrm{~s} / \mathrm{m}^{3}$. The doses during this timeframe are therefore

$$
D(\text { inh, off, } 1-24 \mathrm{~h})=(1.4 \mathrm{E}-2 \mathrm{~L})\left(4.74 \mathrm{E}-6 \mathrm{~s} / \mathrm{m}^{3}\right)\left(3.3 \mathrm{E}-4 \mathrm{~m}^{3} / \mathrm{s}\right)(8.0 \mathrm{E} 4 \mathrm{~Sv} / \mathrm{L})
$$




\section{WHC-SD-WM-CN-O48 Rev $O$}

$$
=1.8 \mathrm{E}-6 \mathrm{SV} \text {. }
$$

Note: to simplify calculation, the above equation conservatively ignores the fall off in breathing rate during the period of time the receptor is at rest.

$$
\begin{aligned}
D(\text { ing, off }, 1-24 \mathrm{~h}) & =(1.4 \mathrm{E}-2 \mathrm{~L})\left(4.74 \mathrm{E}-6 \mathrm{~s} / \mathrm{m}^{3}\right)\left(1.4 \mathrm{sv}-\mathrm{m}^{3} / \mathrm{L}-\mathrm{s}\right) \\
= & 9.3 \mathrm{E}-8 \mathrm{SV}
\end{aligned}
$$

The total offsite dose from both pathways, over both time increments, is:

$$
\text { Dose (total, off })=3.3 \mathrm{E}-6 \mathrm{~Sv}(3.3 \mathrm{E}-4 \mathrm{rem})
$$

\subsection{SPRAY LEAK INSIDE DCRT PUMP PIT}

A review of the pump curves in Appendix $B$ shows that the potential pressures in the DCRT pump pits are as high as in the representative accident. The respirable release rate in tha unmitigated accident can therefore be expected to be similar to the representative case. DCRT pump pit volumes are bounded by the representative cas 3 . Therefore mitigated aerosol releases from the pump pits can be expected to je bounded by the mitigated source term estimated for the representative accident. The consequences differ between the DCRT pump pit case and the resresentative case primarily because of differences in waste inventory. JCRTs receive waste from SSTs and act as 1 ag storage until that waste can be batch transferred to DSTs. The waste inventory inside the DCRTs should therefore be represented by the SST source term.

As in the representative caie, it is assumed the DCRT transfer pumps can entrain a maximum of $33 \mathrm{vol} \%$ solids. The unmitigated and mitigated doses can be simply estimated by multiplyiny the doses determined in the representative case by the ratio of the SST wast? composite ULD over the aging waste composite ULD.

For an SST waste stream con aining 33 vol \% solids, the composite inhalation and ingestion ULDs, from Section 6.2.2.1 are:

DST composite $U_{\text {ULD }}=8.0 E 4 \mathrm{SV} / \mathrm{L}$

DST composite ULD ing $=1.4 \mathrm{~S} /-\mathrm{m}^{3} / \mathrm{L}-\mathrm{S}$

These ULDs compare to $5.6 \mathrm{E} 5 \mathrm{~Sv} / \mathrm{L}$ and $2.7 \mathrm{~Sv}-\mathrm{m}^{3} / \mathrm{L}-\mathrm{s}$, respectively for the aging waste case.

\subsubsection{Unmitigated Accident Doses}

Ratioing the doses reported in Section 4.1.1 for the unmitigated scenario gives the following resu ts:

Onsite Dose

$D($ inh.on $)=(150 \mathrm{SV})(8.0 \mathrm{E} 4 \mathrm{S \textrm {V } / \mathrm { L }}) /(5.6 \mathrm{E} 5 \mathrm{SV} / \mathrm{L})$

$=21 \mathrm{SV}(2100 \mathrm{rem})$

$$
23 \text { of } 98
$$




$$
W H C-S D-W M-C N-O 48 \text {, ReV } O
$$

\section{Offsite Dose}

$$
\begin{aligned}
D(\text { inh, off }) & =(0.21 \mathrm{~Sv})(8.0 \mathrm{E}+\mathrm{Sv} / \mathrm{L}) /(5.6 \mathrm{E} 5 \mathrm{~Sv} / \mathrm{L}) \\
= & 3.0 \mathrm{E}-2 \mathrm{~Sv}(3.0 \mathrm{r} \cdot \mathrm{m}) \\
D(\text { ing, off }) & =(3.7 \mathrm{E}-3 \mathrm{~Sv})\left(1 .+\mathrm{Sv}-\mathrm{m}^{3} / \mathrm{L}-\mathrm{s}\right) /\left(2.7 \mathrm{~Sv}-\mathrm{m}^{3} / \mathrm{L}-\mathrm{s}\right) \\
= & 1.9 \mathrm{E}-3 \mathrm{~Sv}(0.19 \mathrm{em}) \\
D \text { (tot, off }) & =3.2 \mathrm{E}-2 \mathrm{~Sv}(3.2 \mathrm{rem})
\end{aligned}
$$

\subsubsection{Mitigated Accident Doses}

results:

Ratioing the doses reported in Section 4.2.1.1 gives the following

Onsite Dose

$$
\begin{aligned}
\mathrm{D}(\text { inh, on, } \mathrm{lh})= & (3.6 \mathrm{E}-2 \mathrm{SV})(3.0 \mathrm{E} 4 \mathrm{SV} / \mathrm{L}) /(5.6 \mathrm{E} 5 \mathrm{SV} / \mathrm{L}) \\
= & 5.1 \mathrm{E}-3 \mathrm{SV} \\
\mathrm{D}(\text { inh, on }, 1-12 \mathrm{~h}) & =(3.8 \mathrm{E}-3 \mathrm{S \prime})(8.0 \mathrm{E} \mathrm{SV} / \mathrm{L}) /(5.6 \mathrm{ES} \mathrm{SV} / \mathrm{L}) \\
= & 5.4 \mathrm{E}-4 \mathrm{SV}
\end{aligned}
$$

The total onsite dose is:

$$
\begin{aligned}
& D(\text { tot, on })=5.6 \mathrm{E}-3 \mathrm{~Sv}(0.56 \mathrm{rem}) \\
& \text { Offsite Dose } \\
& D(\text { off, inh, lh })=(3 E-5 \mathrm{SV})(8.0 \mathrm{E} 4 \mathrm{SV} / \mathrm{L}) /(5.6 \mathrm{E} 5 \mathrm{SV} / \mathrm{L}) \\
& =4.3 \mathrm{E}-6 \mathrm{~Sv}(4 . \mathrm{E}-4 \mathrm{rem}) \\
& \left.D(\text { off, ing, } 1 \mathrm{~h})=(4.4 \mathrm{E}-7 \mathrm{SV}) / 1.4 \mathrm{SV}-\mathrm{m}^{3} / \mathrm{L}-\mathrm{s}\right) /\left(2.7 \mathrm{~Sv}-\mathrm{m}^{3} / \mathrm{L}-\mathrm{s}\right) \\
& =2.3 \mathrm{E}-7 \text { SV }(2 . \therefore \mathrm{E}-5 \text { rem) } \\
& D(\text { off, inh, } 1-24 h)=(6.6 \mathrm{E}-6 \leq \mathrm{v})(8.0 \mathrm{E} 4 \mathrm{~Sv} / \mathrm{L}) /(5.6 \mathrm{E} 5 \mathrm{SV} / \mathrm{L}) \\
& =9.4 \mathrm{E}-7 \mathrm{SV}(9.4 \mathrm{E}-5 \mathrm{rem}) \\
& D \text { (off, ing, } 1-24 \mathrm{~h})=(9.6 \mathrm{E}-8 \mathrm{sv})\left(1.4 \mathrm{~Sv}-\mathrm{m}^{3} / \mathrm{L}-\mathrm{s}\right) /\left(2.7 \mathrm{~Sv}-\mathrm{m}^{3} / \mathrm{L}-\mathrm{s}\right) \\
& =5.0 \mathrm{E}-8 \mathrm{SV} \text { (5.) (E-6 rem) }
\end{aligned}
$$

The total offsite dose is

$$
D \text { (off, tot })=5.5 E-6 \text { Sv (5.5E-4 rem) }
$$




$$
\text { WHC-SD-WM-CN-048, RevO }
$$

\subsection{COMPARISON WITH REPRESENTATIVE CASE AND WITH EVALUATION GUIDELINES}

Table 6-l summarizes the results for the three additional spray leak sites and compares them with the TWRS evaluation guidelines. The table shows that the three additional spray leak sites are bounded by the representative case. Although the doses for the DST valve pit, SST pump pit, and DCRT pump pit cases are lower than for the representative case, the unmitigated offsite doses are still well above the EG for the Anticipated category. The unmitigated onsite doses are orders of magnitude above the onsite $E G$ for the Anticipated frequency category. The represented cases, like the representative case all warrant safety class mitigation.

The mitigated doses for all cases demonstrate that the pit cover blocks are adequate to mitigate doses to below the offsite EGs. The mitigated onsite doses for the DST valve pit and DCRT pump pit cases are marginally above the onsite EG for the Anticipated frequency category. The mitigated SST pump pit case gives an onsite dose marginally below the EG for the Anticipated frequency category. The pit cover blocks are shown to be sufficient to prevent safety class consequence (significant consequences to the of $\mathrm{f}$ site receptor). Further controls should, however, be considered to prevent significant consequences to the onsite receptor. 


\section{WHC-SD-WM-CN-O48 ReV O}

\subsection{SI:NSITIVITY ANALYSIS}

Within the TWRS transfer systems, spray leaks can occur at a variety of pressures, involving waste with differing characteristics. Leak dimensions are also highly variable. The source term and consequence analyses above were performed in a conservative manner. This section examines the sensitivity of the spray leak results to key parameters and assumptions.

Since the mitigated consequences were shown in all cases analyzed above to be below guidelines, the sensitivity analysis is performed only for the unmitigated accident model. The representative accident analyzed in Sections 2 through 4 was a spray leak inside a DST valve pit. For the unmitigated model the parameters and assumptions that have a substantial impact on dose consequences are: waste type, waste solids content, leak dimensions (assumed crack width, and crack depth), and assumed accident duration. The bounding spray leak analyzed in Sections 2 through 4 was a leak of aging waste, containing 33 vol \% entrained solids, through an optimally sized hole at the maximum pressure possible in the DST transfer systems.

The effects of variations in each of the above 1isted parameters on the source term and dose consequence analyses are addressed in Sections 7.1 through 7.4 below. Section 7.5 combines "nominal" values for each parameter in a consequence analysis to give some idea for the range of risk associated with pressurized spray releases.

\subsection{WASTE TYPE AND SOLIDS LOADINa}

Spray leaks within the TWRS transfer systems can consist of three waste types: aging waste, DST waste, and SST waste. Any of these waste types can be transferred through a DST valve pit. The solids content of the waste being transferred is also variable. The effect on the doses for each waste type at various assumed solids loadings $c$ an be evaluated by comparing the unit liter dose (ULD) values from Table 4-1.

The consequence analyses in the previous sections show that the $24-\mathrm{h}$ ingestion dose comprises a small sercentage of the total offsite dose. The sensitivity of the analysis can tierefore be adequately assessed by comparing inhalation ULDs.

Table 4-1 shows that waste :ank solids have a higher dose potential than waste tank liquids, with aging waste solids producing significantly higher doses than the other waste types. The waste sprayed in the unmitigated analysis for the representative a:cident was assumed to be aging waste containing 33 vol \% entrained solids. This assumption is judged to be bounding, as discussed previously. Grab samples taken from supernate layers in DSTs and measured sludge level changes in receiving tanks following transfers, however, indicate that typical transfers contain only trace amounts to 5 vol \% solids.

Table 7-l gives the composi :e inhalation ULDs for each waste type (aging waste, DST waste, SST waste), at :hree different solids loadings--33 vol \% solids, 5 vol \% solids, and 1 vol \% solids. These values were determined by combining the solids and liquids IJLDs from Table 4-1, using the appropriate solids and liquids volume weighting factors. The last column of the table 


$$
\text { WHC-SD-WM-CN-OY8 ReVO }
$$

gives a ratio of the computed ULD for each case relative to the base (representative accident) case. The 33 vol \% solids cases are bounding for each waste type. The 5 vol \% solids cases are judged to represent the nominal waste composition in a transfer line. The 1 vol \% solids cases were determined to represent the "low and" and to take into account the possibility that the leakage path could filter out entrained solids.

Table 7-1 shows that DST waste at a 33 vol \% solids loading will produce doses $3.2 \%$ of those produced in the base case. SST waste at 33 vol \% produces doses about $14 \%$ of those produced in the aging waste base case. At the low end (i.e., at 1 vol \% solids loading), DST and SST are shown to produce doses of $3.8 \%$ and $2.3 \%$, respectively, of the base case.

\subsection{WASTE PRESSURE}

Waste pressure effects the espirable aerosol release rate and hence the doses, because it determines the relocity of the jet exiting through a given size orifice (based on Bernoulli'; equation). The dimensions of the jet, the kinematic viscosity of the liquid, and the jet velocity determine the particle size distribution and respirable lerosol generation rate. A parametric study of all variables involved in dete mining the respirable aerosol release rate is beyond the scope of this calculation. An idea of the sensitivity of this analysis to waste pressure can be gained by varying pressure and using the SPRAY code to solve for the maxim im respirable aerosol release at each selected pressure.

Depending on the location 0 : the leak with respect to the transfer pump, transfer line length and resistan:e, static assist, apparent waste viscosity at pipe shear rates, etc., the prissure of the waste at the leak location under flowing conditions could va'y anywhere from just above atmospheric to the bounding $300 \mathrm{psig}$ pressure usted in the representative analysis. Two cases were looked at to assess sensitiv ty: a 150 psig case and a 50 psig case. The crack length, crack depth, and wa:ite viscosity used were the same as in the representative case. The input and output files for the SPRAY runs are included in Appendix $C$ as Cases 3 and 4, respectively.

The optimum spray in the 1511 psig case was found to produce a respirable aerosol flowrate of $6.47 \mathrm{E}-2 \mathrm{~L} / \mathrm{min}$ The optimally sized crack in the $50 \mathrm{psig}$ case was found to produce a respirable aerosol flowrate of $9.96 \mathrm{E}-3 \mathrm{~L} / \mathrm{min}$. The representative accident at 300 ps. $^{\circ}$ produced a respirable flow of $0.21 \mathrm{~L} / \mathrm{min}$. The ratios of the doses expected ' $n$ the $150 \mathrm{psig}$ and 50 psig cases to the 300 psig case are therefore 0.31 and $4.7 \mathrm{E}-2$, respectively. The $150 \mathrm{psig}$ case produces doses about one third as high as in the representative case. The 50 psig case produces maximum doses ibout $5 \%$ of the representative case.

\subsection{LEAK DIMENSIONS}

\subsubsection{Slit Length}

The spray code determines the total flowrate through the leak path based on Bernoulli's equation, using the hydraulic radius of the slit. The total flowrate and respirable aerosol flowrate are therefore approximately proportional to the length of the slit assumed, at any given pressure. Doses

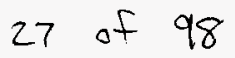




$$
\text { WHC-SD-INM-CN-O48 ReV O }
$$

for other slit lengths can be scaled from the doses for the specific case analyzed.

\subsubsection{Slit Width}

In the representative accident, the spray code was used to iteratively solve for the slit width that profuced the maximum flowrate of respirable sized aerosols. The optimum slit width was found to be $4.5 \mathrm{E}-3$ in. To examine the sensitivity of the source tern analysis to this parameter, two other slit widths were looked at: 0.01 inches and 0.1 inches. Nozzles in the spray drying industry tend to be 0.01 i ches in diameter or larger. Problems with plugging are experienced with nozlle diameters below this size. The second slit width was selected to look at the effect of an order of magnitude change in this parameter.

The results for both cases are included in Appendix $C$ as Cases 5 and 6 . The same waste pressure, slit lenjth, slit depth, and viscosity were assumed as in the representative accident. For the 0.01 in wide slit, the respirable aerosol release rate was found to be $0.14 \mathrm{~L} / \mathrm{min}$. For the 0.1 in wide slit, the respirable aerosol release rase was found to be $4.0 \mathrm{E}-3 \mathrm{~L} / \mathrm{min}$. These compare to a respirable aerosol rulease rate for the optimally sized slit of $0.28 \mathrm{~L} / \mathrm{min}$. The 0.01 in crack pr sduces a dose half as large as the representative case. The 0.1 in :rack produces doses about $1.4 \%$ as high as the representative case.

The combined effects of var,ing this parameter with other variables, such as waste pressure are beyond the scope of this analysis.

\subsubsection{Slit Depth}

The slit depth and the surfice roughness of the base material the leak develops in effect the Darcy fric "ional losses across the depth of the leak. For very narrow cracks, the ratio of the depth of the crack (L) to the width of the crack (D) can be very high Higher $L / D$ ratios give higher pressure drops across the depth of the crack and lower respirable aerosol production.

The representative accident credited Darcy frictional losses across a schedule 40 pipe thickness. Postulated spray leaks within valve pits occur in schedule 40 piping, or through otler equipment (jumpers, seals, gaskets) that can be expected to produce similar frictional losses to those credited in the representative case. No sensitiv ty study was therefore performed on this parameter.

\subsection{ACCIDENT DURATION}

The unmitigated spray leak ' $n$ the representative accident is assumed to continue unabated for 24 hours. The total respirable aerosol release (e.g. source term) is directly proporticnal to the assumed accident duration, because the release rate is constint. However, changing wind direction, wind speed, and atmospheric stability result in a logarithmically decreasing $X / Q^{\prime}$ as a function of time. This effect is demonstrated in Table $D-3$.

The effect of assumed accident duration on the unmitigated dose analysis can be determined by selecting a release duration, multiplying that duration 


\section{WHC-SD-WM-CN-OY Rev $\mathrm{C}$}

by the appropriate $X / Q^{\prime}$ and comparing to the similarly derived product at a different release duration. Using the $X / Q^{\prime}$ 's from Table $D-3$, the offsite dose for a 2 hour, unmitigated spray release can be shown to be $38 \%$ as high as the dose for a 24 hour spray release. Conversely, increasing the accident duration to 3 days can be shown to produce a dose only about a factor of 1.5 times higher than the 24 hour case.

\subsection{METEOROLOGY}

Deleted.

\subsection{NOMINAL CASE}

A detailed parametric study or Monte Carlo analysis is beyond the scope of this calculation note. However, an idea for the sensitivity of the analysis to the key parameters can be gained by examining a scenario where some of the conservatism is removed from each key parameter. This section evaluates a "nominal" unmitigated (i.e., uncovered) spray leak.

For this "nominal" case, it is assumed that the waste being sprayed consists of DST waste with a solifs loading of 5 vol \%. DST waste is pumped more often than aging waste and is appropriate to use for the nominal case. The 5 vol \% entrained solids assunption is judged to be representative of typical supernate waste transfers, based on grab sample results and sludge level readings taken in supernate receiving tanks. A nominal waste pressure of $150 \mathrm{psig}$ is assumed. The 300 osig pressure assumed in the bounding representative accident is only expected if the pump deadheads or if the transfer path is very long (providing a lot of line resistance) and the spray leak develops in a pit very close to the transfer pump). The $150 \mathrm{psig}$ pressure is judged to be more representative of pressures at potential leak sites during typical transfers and for cases where leaks develop in pits a considerable distance away from tie transfer pump (i.e., near the receipt tank, or beyond the half way point).

For the nominal case, it is also assumed that the crack length is 1 in. and that the crack width is $0.01 \mathrm{in}$. Since transfers are accomplished through 3 in supernate 1 ines more often tian 2 in siurry lines, the crack depth in the nominal case is assumed to be $0.216 \mathrm{in}$. (the depth of a $3 \mathrm{in}$, schedule 40 pipe). Since the waste in the noluinal case is assumed to contain 5 vol \% solids, an SpG of 1.2 is assumed. This value is between the 1.1 SpG typically measured on supernate samples and the $1.4 \mathrm{SpG}$ assumed for the 33 vol \% case. Because of evaporation, particles greater than 10 um in diameter can shrink down to respirable size. The dianeter of the maximum sized particle that can shrink tc 10 um is calculated with the following equation.

$$
D_{2}=\left(D_{1}^{3} / E\right)^{(1 / 3)}
$$

where,

$D_{1}=10$ um

$\mathrm{D}_{2}=$ radius of starting particle

$E^{2}=$ volume fraction solids 


\section{$W H C-5 D-W M-C N-048$ RevO}

For a solution containing 5 vol \% solids, the above equation gives a starting particle size of $27 \mathrm{um}$.

The input and output files for the SPRAY run using the above "nominal" values are included as Case 7 in Appendix $C$. The respirable aerosol release rate was found to be $8.52 \mathrm{E}-2 \mathrm{~L} / \mathrm{min}$. The total flowrate was found to be 10.1 $\mathrm{L} / \mathrm{min}$, giving a respirable release fraction of $8.5 \mathrm{E}-3$.

For this nominal case, it is assumed that the spray leak is detected and the transfer pump shutdown in 2 hours. Tank farm workers monitoring the transfer are likely to discover that the cover block has been left off the valve pit and will radio operators to shutoff the transfer within this time frame. Depending on wind direction a spray leak severe enough to lead to large onsite doses may also be detected by another facility's radiation monitors, which will spur an investigation that will discover the source of the leak within the assumed two hour time frame. Radiation protection technicians doing surveys for other purposes may also detect the leak and investigate. As discussed in the representative accident scenario discussion, valve pit leak detecturs are not sensitive enough to detect low volume spray leaks. Mass balanc ss are not sensitive enough to detect low volume spray leaks in a reasonabl? amount of time.

From Table 7-1, the inhalation ULD for DST waste containing 5 vol $\%$ solids is $3.2 E 4$ Sv/L. The $2-h$ onsite $X / Q^{\prime}$ from Table $D-3$ is $1.13 E-2 \mathrm{~s} / \mathrm{m}^{3}$. Using the respirable aerosol gene ation rate from above and the active receptor breathing rate, the onsize receptor dose is:

$$
\begin{aligned}
D(\text { inh, on }) & \left.=(8.52 \mathrm{E}-2 \mathrm{~L} / \mathrm{min}): 1.13 \mathrm{E}-2 \mathrm{~s} / \mathrm{m}^{3}\right)\left(3.3 \mathrm{E}-4 \mathrm{~m}^{3} / \mathrm{s}\right)(3.2 \mathrm{E} 4 \mathrm{~Sv} / \mathrm{L}) \\
& \times(60 \mathrm{~min} / \mathrm{h})(2 \mathrm{~h}) \\
= & 1.2 \mathrm{SV}(120 \mathrm{rem})
\end{aligned}
$$

The $2-h$ offsite $X / Q^{\prime}$ from Table $D-3$ is $2.12 E-5 \mathrm{~Sv} / \mathrm{L}$. The offsite inhalation dose therefore is

$$
\begin{aligned}
D(\text { inh, off }) & =\left(8.52 \mathrm{E}-2 \mathrm{~L} / \mathrm{min}+(2.12 \mathrm{E}-5 \mathrm{~Sv} / \mathrm{L})\left(3.3 \mathrm{E}-4 \mathrm{~m}^{3} / \mathrm{s}\right)(3.2 \mathrm{E} 4 \mathrm{~Sv} / \mathrm{L})\right. \\
& \times(60 \mathrm{~min} / \mathrm{h})(2 \mathrm{~h}) \\
= & 2.3 \mathrm{E}-3 \mathrm{SV}(0.23 \text { "em })
\end{aligned}
$$

For the Anticipated frequency category, the onsite and offsite EGs are 5 $\mathrm{mSV}$ and $1 \mathrm{mSv}$, respectively. The nominal unmitigated spray leak well exceeds the onsite EG and produces offsitu doses that are marginally higher than the offsite EG. The nominal case shows that spray leaks under a variety of conditions pose major safety concerns, and that it is prudent to apply Safety Class level controls to mitigate ur prevent spray leaks throughout the tank farm transfer systems. 


$$
\text { WHC-SD-WM-CN-O48, Rev O }
$$

\section{B.0 OVERALL SUMMARY AND CONCLUSIONS}

Spray leaks within the tank farm transfer systems are Anticipated events. The unmitigated spray leik for the bounding, representative case produces doses that well exceed buth the onsite and offsite evaluation guidelines for the Anticipated fruquency category. In addition, the toxicological consequences of the representative accident exceed the onsite EG. The mitigated accident analy:i is for the representative case demonstrates that the pit cover blocks can suf:iciently mitigate the consequences of the accident (both radiological and tuxicological) to well below the offsite evaluation guideline. The mitigated radiological dose estimate, however, is of the same order of magnitude as the onsite $E G$.

The consequence analyses in Sections 6 and 7 demonstrate that unmitigated (uncovered) spray lealis at potential sites throughout the tank farm transfer systems warrant Safety Class mitigation. The covers for all pits and enclosures (e.g., valve pits, pump pits, sluice pits, diversion boxes, vault pits, etc.) along trinsfer routes and connected to transfer routes where waste could be misrolted should be designated Safety Class. The enclosure covers are the only existing barriers that provide reliable mitigation for spray leaks inside these enclosures. Pit leak detectors and mass balances performed during trinsfers are not sensitive enough to preclude unacceptable consequences to the cnsite receptor and may not be sensitive enough to preclude significant cor sequences offsite.

TSR controls (i.e., LCOs, or ACs) are necessary to ensure covers are on all pits along transfer routes or where waste could be misrouted during transfers. The unmitigated accident dose to the onsite worker is very high and additional measures must be tiken to protect this receptor if the accident can not be made incredible with $T \leqslant R$ controls.

The mitigated accident analjses demonstrate that the cover blocks alone may not be sufficient to prevent significant consequences to the onsite receptor. Additional controls (e.g., safety significant CAMs inside pits, safety significant radiation monitors throughout the tank farms, TSR AC to maintain exclusion areas around pits) should be considered to protect onsite individuals from spray leaks insice covered pits. Alternatively, more sophisticated analyses could be performed to remove some of the conservatisms from the mitigated accident model. 
WHC-SD-WM-CN-C48 Rev O

\subsection{PEER REVIEW}

See Appendix $F$ for peer review checklist. 


\subsection{REFERENCES}

ASHRAE, 1977, ASHRAE Handbook and Product Directory, American Society of Heating, Refrigerating, and Air Conditioning Engineers, New York, New York.

Socolow, R.H., 1994, Exposure to ladon and Radon Progeny in the Indoor Environment, DOE/ER/61030-- 'I, Princeton University Center for Energy and Environmental Studies, I'rinceton, New Jersey.

WHC-CM-4-46, 1995, Nonreactor Fac lity Safety Analysis Manual, Rev. 4, Westinghouse Hanford Compan:, Richland, Washington.

WHC-SD-WM-ER-127, 1991, Evaporatiun Modeling for Tank C-103, Rev. 0, Westinghouse Hanford Compan:", Richland, Washington.

WHC-SD-WM-SARR-011, 1996, Toxicolugical Chemical Considerations for Tank Farm Releases, Rev. 2, Westinghouse Hanford Company, Richland, Washington.

WHC-SD-WM-SARR-016, 1996, Tank Wa:te Compositions and Atmospheric Dispersion Coefficients for Use in Accelerated Safety Analysis Consequence Assessments, Rev. 2, Westing̣house Hanford Company, Richland, Washington.

WHC-SD-WM-SARR-037, 1996, Developnent of Radiological Concentrations and Unit Liter Doses for TWRS FSAR Ridiological Consequence Calculations, Rev. 0 , Westinghouse Hanford Companj, Richland, Washington. 
WHC-SD-NM-CN-C48 REV C

Table 4-1. Unit Liter Joses for Inhalation and Ingestion.

\begin{tabular}{|l|c|c|}
\hline \multicolumn{1}{|c|}{ Composite } & $\begin{array}{c}\text { Inhalation ULD } \\
\text { (Sv } / \mathrm{L})\end{array}$ & $\begin{array}{c}\text { Ingestion ULD } \\
(\text { Sv-m } / \mathrm{s}-\mathrm{L})\end{array}$ \\
\hline Single-shell tank liquids & $1.1 \mathrm{E}+04$ & 0.052 \\
\hline Single-shell tank solids & $2.2 \mathrm{E}+05$ & 4.1 \\
\hline Double-she11 tank liquids & $6.1 \mathrm{E}+03$ & 0.068 \\
\hline Double-shel1 tank solids & $5.3 \mathrm{E}+05$ & 0.48 \\
\hline Aging waste facility liqui js & $1.4 \mathrm{E}+03$ & 0.092 \\
\hline Aging waste facility solids & $1.7 \mathrm{E}+06$ & 8.1 \\
\hline
\end{tabular}

NOTE: The information in this tible is from WHC-SD-WM-SARR-037, 1996, Development of Radiological Concentrations and Ur, it Liter Doses for TWRS FSAR Rádiological

Conseguence Calculations, Westinghou: e Hanford Company, Richland, Washington.

ULD = unit liter dose. 


$$
\text { WHC-SD-WM-CN-C48, Rev O }
$$

Table 4-2. Sum-o:-Fractions for Unit Releases of So' ids and Liquids.

*The sum of fractions are multiplied by the release rate for continuous release and release amount :or a puff releases. Release rates for continuous releases are in units of liters per second for liquids and solids, and $\mathrm{m}^{3} / \mathrm{s}$ for gases. Puff release quantities are in units of liters for solids and liquids and $\mathrm{m}^{3}$ for gases.

\begin{tabular}{|c|c|c|c|c|}
\hline \multirow{2}{*}{$\begin{array}{l}\text { Tank waste type (Units of } \\
\text { sum of fractions follow } \\
\text { tank waste type) }\end{array}$} & \multirow{2}{*}{$\begin{array}{c}\text { Maximum } \\
\text { individual }\end{array}$} & \multicolumn{3}{|c|}{ Accident frequency, $1 / y r$} \\
\hline & & $1-10^{-2}$ & $10^{-2}-10^{-4}$ & $10^{-4}-10^{-6}$ \\
\hline \multicolumn{5}{|c|}{ DST or SST solid or liquid continuous release } \\
\hline Single-shell liquids (s/L) & Onsite & $9.6 E+03$ & $7.5 E+02$ & $2.0 E+02$ \\
\hline Single-shell liquids (s/L) & offsite & $8.0 E+00$ & $8.0 E+00$ & $6.2 E-01$ \\
\hline Single-shell solids(s/L) & Onsite & $4.0 \quad E+04$ & $2.1 E+04$ & $1.0 E+03$ \\
\hline Single-shell solids(s/L) & offsite & $9.4 E+01$ & $3.3 E+01$ & $1.7 E+01$ \\
\hline Double-she11 liquids(s/L) & Onsite & $1.0 E+04$ & $7.5 E+02$ & $2.1 E+02$ \\
\hline Double-shel1 Tiquids (s/L) & Offsite & $8.4 E+00$ & $8.4 E+00$ & $6.2 \mathrm{E}-01$ \\
\hline Double-shell solids (s/L) & Onsite & $1.8 E+04$ & $3.3 E+03$ & $6.3 \mathrm{E}+02$ \\
\hline Double-shell solids (s/L) & Offsite & $1.9 \mathrm{E}+02$ & $1.5 E+01$ & $2.8 \mathrm{E}+00$ \\
\hline \multicolumn{5}{|c|}{ DST or SST liquid or solid puff release } \\
\hline Single-shel1 liquids $\left(\mathrm{L}^{-1}\right)$ & Onsite & $2.8 E+03$ & $2.2 \mathrm{E}+02$ & $5.7 \mathrm{E}+01$ \\
\hline Single-she 117 iquids $\left(\mathrm{L}^{-1}\right)$ & Offsite & $3.2 E-02$ & $3.2 E-02$ & $2.5 E-03$ \\
\hline Single-shell solids $\left(\mathrm{L}^{-1}\right)$ & Onsite & $1.2 E+04$ & $6.0 E+03$ & $2.9 E+02$ \\
\hline Single-shell solids $\left(\mathrm{L}^{-1}\right)$ & Offsite & $3.8 E-01$ & $1.3 E-01$ & $6.9 E-02$ \\
\hline Double-shel1 liquids $\left(\mathrm{L}^{-1}\right)$ & Onsite & $2.9 E+03$ & $2.2 E+02$ & $6.0 E+01$ \\
\hline Double-shel1 liquids $\left(\mathrm{L}^{-1}\right)$ & Offsite & $3.4 E-02$ & $3.4 E-02$ & $2.5 E-03$ \\
\hline Double-shell solids $\left(\mathrm{L}^{-1}\right)$ & Onsite & $5.2 E+03$ & $9.7 \mathrm{E}+02$ & $1.8 \mathrm{E}+02$ \\
\hline Double-shell solids $\left(\mathrm{L}^{-1}\right)$ & Onsite & $7.7 \mathrm{E}-01$ & $5.9 E-02$ & $1.1 E-02$ \\
\hline
\end{tabular}


WHC-SD-WM-CN-C48 REV C

Table 5-1. Consequences of Valve Pit Spray Leak.

\begin{tabular}{|c|c|c|c|c|c|}
\hline \multirow[t]{2}{*}{ Receptor/Hazard } & \multicolumn{2}{|c|}{ Calculated DC se/Exposure } & \multicolumn{3}{|c|}{ Evaluat ion guidel ine } \\
\hline & Unmi tigated & Mitigated & Anticipated & Unl ikely & $\begin{array}{l}\text { Extremely } \\
\text { Unl ikely }\end{array}$ \\
\hline offsite/radiological & $210 \mathrm{mSv}$ & $3.7 \mathrm{E}-02 \mathrm{mSV}$ & $1 \mathrm{mSv}$ & $5 \mathrm{msv}$ & $40 \mathrm{mSv}$ \\
\hline Onsite/radiological & $150 \mathrm{sv}$ & $40 \mathrm{mSv}$ & $5 \mathrm{mSV}$ & $50 \mathrm{mSV}$ & $100 \mathrm{mSV}$ \\
\hline $\begin{array}{l}\text { offsite/toxicological } \\
\text { sum-of-fractions }\end{array}$ & 0.24 & $4.2 E-04$ & 1 & 1 & 1 \\
\hline $\begin{array}{l}\text { Onsite/toxicological } \\
\text { sum-of-fractions }\end{array}$ & 46 & 0.11 & 1 & 1 & 1 \\
\hline
\end{tabular}

Table 6-1. Dose Cor sequences of Represented Cases

\begin{tabular}{|c|c|c|c|c|c|}
\hline \multirow[t]{2}{*}{ Receptor } & \multicolumn{2}{|c|}{ Calculat d Dose } & \multicolumn{3}{|c|}{ Evaluation guidel ine } \\
\hline & Unmitigated & Mitigated & Anticipated & Untikely & $\begin{array}{l}\text { Extrenely } \\
\text { Unl ikely }\end{array}$ \\
\hline \multicolumn{6}{|c|}{ Spray Leak of DSI Waste Inside Valve Pit } \\
\hline Offsite & $68 \mathrm{mSv}$ & $1.2 \mathrm{E}-02 \mathrm{mSV}$ & $1 \mathrm{msv}$ & $5 \mathrm{mSv}$ & $40 \mathrm{mSv}$ \\
\hline Onsite & $48 \mathrm{SV}$ & $13 \mathrm{mSv}$ & $5 \mathrm{mSv}$ & $50 \mathrm{msv}$ & $100 \mathrm{mSv}$ \\
\hline \multicolumn{6}{|c|}{ Spray Leak Inside SST Pump Pit } \\
\hline offsite & $4.5 \mathrm{mSv}$ & $-3.3 \mathrm{E}-3 \mathrm{mSV}$ & $1 \mathrm{msv}$ & $5 \mathrm{mSv}$ & $40 \mathrm{mSV}$ \\
\hline Onsite & $3.1 \mathrm{sv}$ & $-2.6 \mathrm{mSV}$ & $5 \mathrm{mSv}$ & $50 \mathrm{msv}$ & $100 \mathrm{mSv}$ \\
\hline \multicolumn{6}{|c|}{ Spray Leak Inside DCRT Pump Pit } \\
\hline Offsite & $32 \mathrm{msv}$ & $-5.5 \mathrm{E}-3 \mathrm{mSv}$ & $1 \mathrm{mSv}$ & $5 \mathrm{mSv}$ & $40 \mathrm{mSV}$ \\
\hline Onsite & $21 \mathrm{sv}$ & $5.6 \mathrm{mSV}$ & $5 \mathrm{msv}$ & $50 \mathrm{mSv}$ & $100 \mathrm{msv}$ \\
\hline
\end{tabular}


$W H C-5 N-W M-C N-048 R+V 0$

Table 7-1. Waste Type LLDs as a Function of Solids Loading

\begin{tabular}{||l|l|l|l||}
\hline Waste Type & $\begin{array}{l}\text { Solids Loading } \\
(\text { vol \% })\end{array}$ & $\begin{array}{l}\text { Composite } \\
\text { Inhalation ULD } \\
\text { (Sv/L) }\end{array}$ & $\begin{array}{l}\text { Ratio to ULD for } \\
\text { aging waste at } \\
33 \text { vol solids }\end{array}$ \\
\hline Aging Waste & 33 & $5.6 \mathrm{E} 5$ & 1.0 \\
\hline Aging Waste & 5 & $8.6 \mathrm{E} 4$ & 0.15 \\
\hline Aging Waste & 1 & $1.8 \mathrm{E} 4$ & 0.032 \\
\hline DST Waste & 33 & $1.8 \mathrm{E} 5$ & 0.32 \\
\hline DST Waste & 5 & $3.2 \mathrm{E} 4$ & 0.057 \\
\hline DST Waste & 1 & $1.1 \mathrm{E} 4$ & 0.020 \\
\hline SST Waste & 33 & $8.0 \mathrm{E} 4$ & 0.14 \\
\hline SST Waste & 5 & $2.1 \mathrm{E} 4$ & 0.038 \\
\hline SST Waste & 1 & $1.3 \mathrm{E} 4$ & 0.023 \\
\hline
\end{tabular}


$W H C-50-W M-C N-48$, levo

\section{Appendix A}

Surmmary of Occurre ice Reports Relating to Leaks

from Tank Farm Transfer Equipment inside Transfer Enclosures

38 of 98 


\section{$W H(-5)-W M-C-C-i 8$ Rev 0}

\section{Appendix A}

The following table provide; a summary of the occurrence reports (both unusual and offnormal) relating $t_{1}$ ) leaks of waste, flush water, or hydrostatic testing water involving tank farm transfer system components. Included are process pits and other enclosures along transfer routes. The detailed occurrence reports can be found in the DOE reading room.

Table A-1. Historical Spray'Liquid Leaks Inside Transfer Enclosures

\begin{tabular}{|c|c|c|c|}
\hline $\begin{array}{l}\text { Occurrence } \\
\text { Number }\end{array}$ & Date & Leak T./pe & Description \\
\hline $72-72$ & $11 / 20 / 72$ & $\begin{array}{l}\text { spray inside } \\
\text { pit }\end{array}$ & $\begin{array}{l}\text { Leak from transfer } 1 \text { ine during } \\
\text { flushing caused spray up through } \\
\text { valve operator holes in valve pit } \\
\text { cover. Leak was caused by gasket } \\
\text { failure. }\end{array}$ \\
\hline $75-78$ & $7 / 16 / 75$ & $\begin{array}{l}\text { Liquid'spray } \\
\text { leak inside } \\
\text { diversion } \\
\text { box }\end{array}$ & $\begin{array}{l}\text { Jumper connector failure during } \\
\text { waste transfer from 107-TX to 103- } \\
U \text { causes leak. Jumper located in } \\
\text { 153-TXR diversion box. Cause for } \\
\text { leak: threads were stripped on } \\
\text { flex jumper. }\end{array}$ \\
\hline $76-131$ & $9 / 27 / 76$ & $\begin{array}{l}\text { leak inside } \\
\text { pit }\end{array}$ & $\begin{array}{l}\text { Radioactive waste spill during } \\
\text { jumper disconnection in l05-U pump } \\
\text { pit. Cause: waste transfer } \\
\text { ongoing in adjacent tank } \\
\text { pressurized jumper due to partial } \\
\text { fajlure of a closed valve. }\end{array}$ \\
\hline $76-136$ & $10 / 05 / 76$ & $\begin{array}{l}\text { spray eak } \\
\text { in pit }\end{array}$ & $\begin{array}{l}\text { Radioactive liquid sprayed from a } \\
\text { check valve under repair onto } \\
\text { three personnel in BX Tank Farm. } \\
\text { Cause: preparations for the repair } \\
\text { were inadequate. }\end{array}$ \\
\hline $77-23$ & $2 / 07 / 77$ & $\begin{array}{l}\text { leak iliside } \\
\text { enclosilre }\end{array}$ & $\begin{array}{l}\text { Water leakage inside } 108-B X \text { flush } \\
\text { pit (drained to tank } 108-B X \text { ). } \\
\text { Cause: water valve bonnet blew off } \\
\text { during flush of } 1 \text { ine between } 110- \\
\text { BY and } 105-B X \text {. }\end{array}$ \\
\hline $77-189$ & $10 / 19 / 77$ & $\begin{array}{l}\text { leak irto } \\
\text { pit }\end{array}$ & $\begin{array}{l}\text { Failure of blank between pump pit } \\
\text { and leak detection pit results in } \\
\text { contamination spread to } 102-5 y \\
\text { annulus. }\end{array}$ \\
\hline $77-205$ & $12 / 06 / 77$ & $\begin{array}{l}\text { spray leak } \\
\text { inside pit }\end{array}$ & $\begin{array}{l}\text { Spray leak from } 111-5 \text { pump pit } \\
\text { during leak check of salt well } \\
\text { pump and jumpers. The leak check } \\
\text { was not done with cover blocks } \\
\text { installed. Cause: failed gasket } \\
\text { at pump inlet flange. }\end{array}$ \\
\hline
\end{tabular}


WHC-SD-WM-CN-O48 Rev C

\begin{tabular}{|c|c|c|c|}
\hline $80-81$ & $8 / 26 / 80$ & $\begin{array}{l}\text { spray nside } \\
\text { pit }\end{array}$ & $\begin{array}{l}\text { Spray leak in 241-AW-05A central } \\
\text { pump pit during slurry transfer to } \\
\text { Tank 105-AW. Cause: worker unable } \\
\text { to tighten connection between } \\
\text { jumper and distributor } \\
\text { sufficiently. }\end{array}$ \\
\hline $83-34$ & $12 / 12 / 83$ & $\begin{array}{l}\text { spray/ iquid } \\
\text { releasi? } \\
\text { inside } \\
\text { cleanout box } \\
\text { (many tases) }\end{array}$ & $\begin{array}{l}\text { Smearable contamination in } 200- \\
\text { East area cleanout boxes. Cause: } \\
\text { assumed deterioration of plug } \\
\text { seals on the center riser of the } \\
\text { coBs. }\end{array}$ \\
\hline $\begin{array}{l}\text { WHC- } \\
\text { TANKFARM- } \\
1993-08\end{array}$ & $1 / 15 / 93$ & leak to pit & $\begin{array}{l}\text { Transfer from 204-AR to 101-AY } \\
\text { failed due to frozen jumpers in } \\
\text { path. }\end{array}$ \\
\hline $\begin{array}{l}\text { WHC- } \\
\text { TANKFARM- } \\
1994-62\end{array}$ & $11 / 2 / 94$ & $\begin{array}{l}\text { spray and/or } \\
\text { liquid leak } \\
\text { inside pit }\end{array}$ & $\begin{array}{l}\text { During saltwell pumping of 109-BY } \\
\text { a high radiation dose was measured } \\
\text { over the pump pit. The saltwell } \\
\text { pump discharge developed a leak. }\end{array}$ \\
\hline $\begin{array}{l}\text { WHC- } \\
\text { TANKFARM- } \\
1995-23\end{array}$ & $3 / 7 / 95$ & $\begin{array}{l}\text { leak irside } \\
\text { pit }\end{array}$ & $\begin{array}{l}\text { Transfer from } 204-A R \text { to } 102-A Y \\
\text { leaked into } 241-A-A \text { valve pit } \\
\text { through nozzle. Leak drained into } \\
\text { catch tank } A-350 \text {. }\end{array}$ \\
\hline $\begin{array}{l}\text { WHC- } \\
\text { TANKFARM- } \\
1995-41\end{array}$ & $4 / 13 / 95$ & $\begin{array}{l}\text { spray and/or } \\
\text { liquid } \\
\text { releast: } \\
\text { inside pit }\end{array}$ & $\begin{array}{l}\text { Leak found by 244-A camera crew } \\
\text { during B Plant transfer. }\end{array}$ \\
\hline $\begin{array}{l}\text { WHC- } \\
\text { TANKFARM- } \\
1995-81\end{array}$ & $10 / 4 / 95$ & $\begin{array}{l}\text { leak irside } \\
\text { pit }\end{array}$ & $\begin{array}{l}\text { Transfer line SN- } 274 \text { leaked during } \\
\text { transfer between AX-B valve pit } \\
\text { and } 101-A N \text {. Leak at flexible } \\
\text { jumper connection. } 2 \text { gallons } \\
\text { leaked. }\end{array}$ \\
\hline
\end{tabular}


WHC-SD-WM-CN-OY8 ReV O

Appendix B

TW:S Pump Curves

41 of 98 
WHC-5O-WM-CN-O48 REV. O

DST/AW Iransfer Pump Curves

42 of 98 
WHC-SD-WM-CN-O48 ReV O

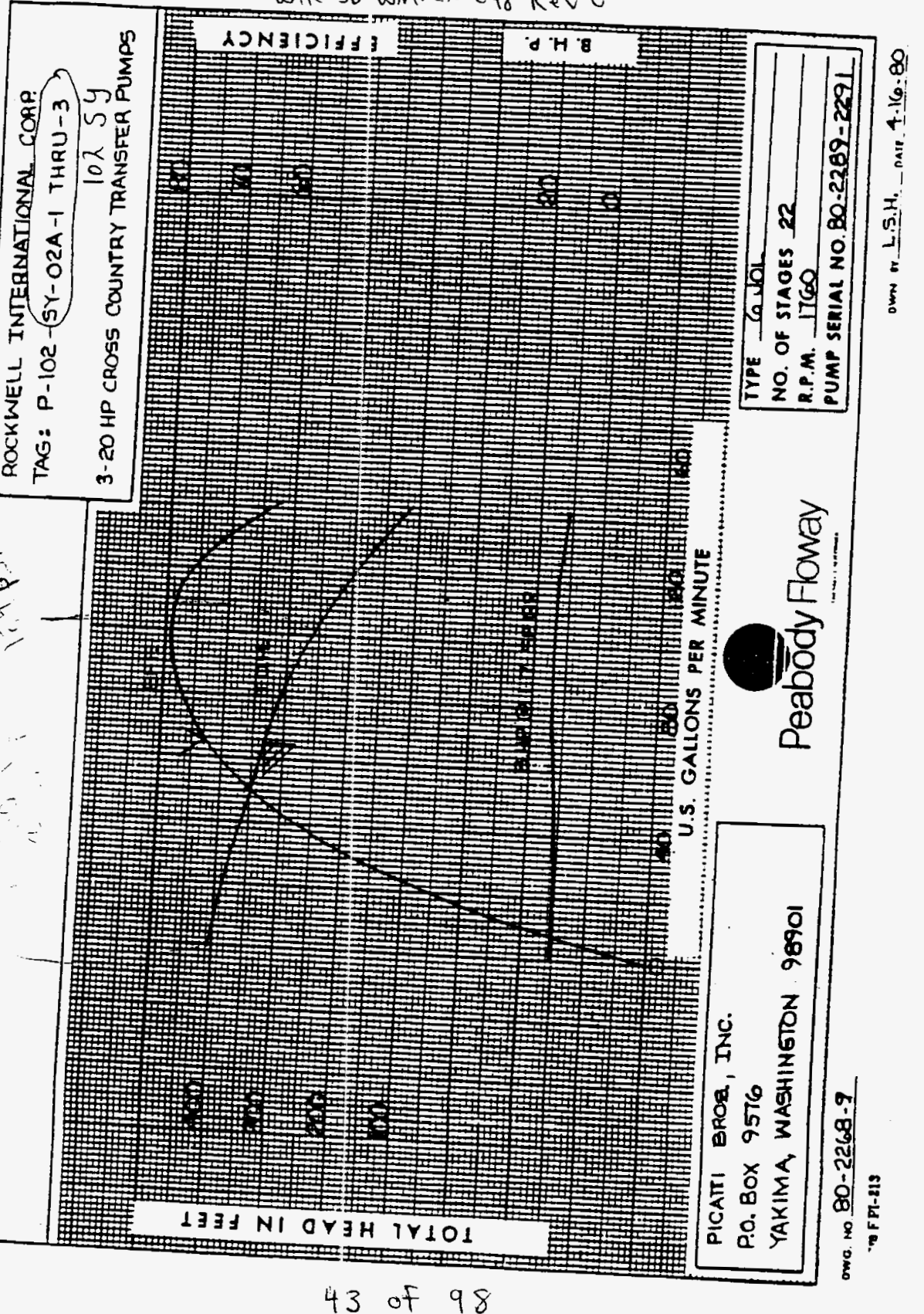


86 to thit

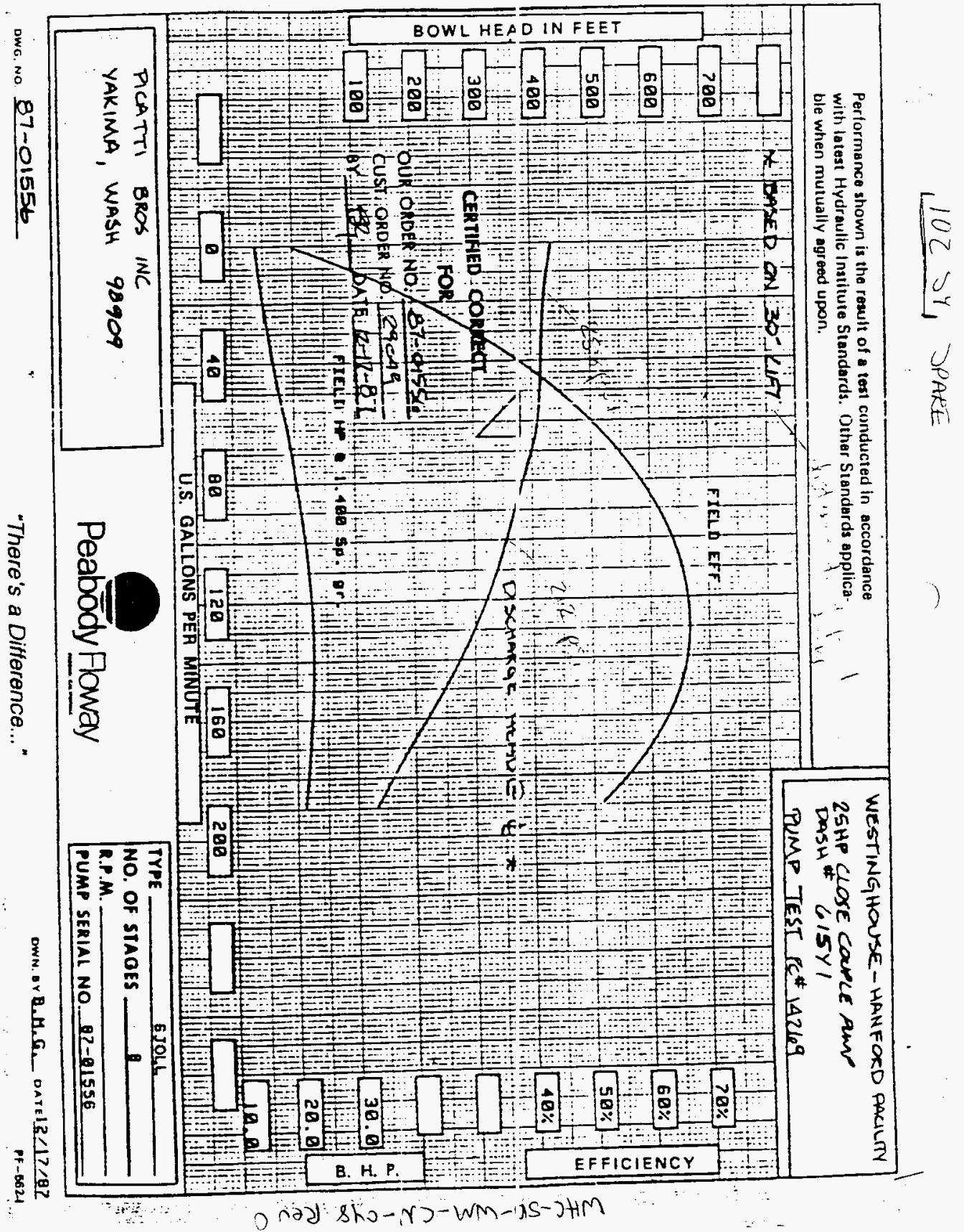


WHC-S:D-WM-CN-O48 REV C

DCRT Transfur Pump Curves and Data

ths of 98 


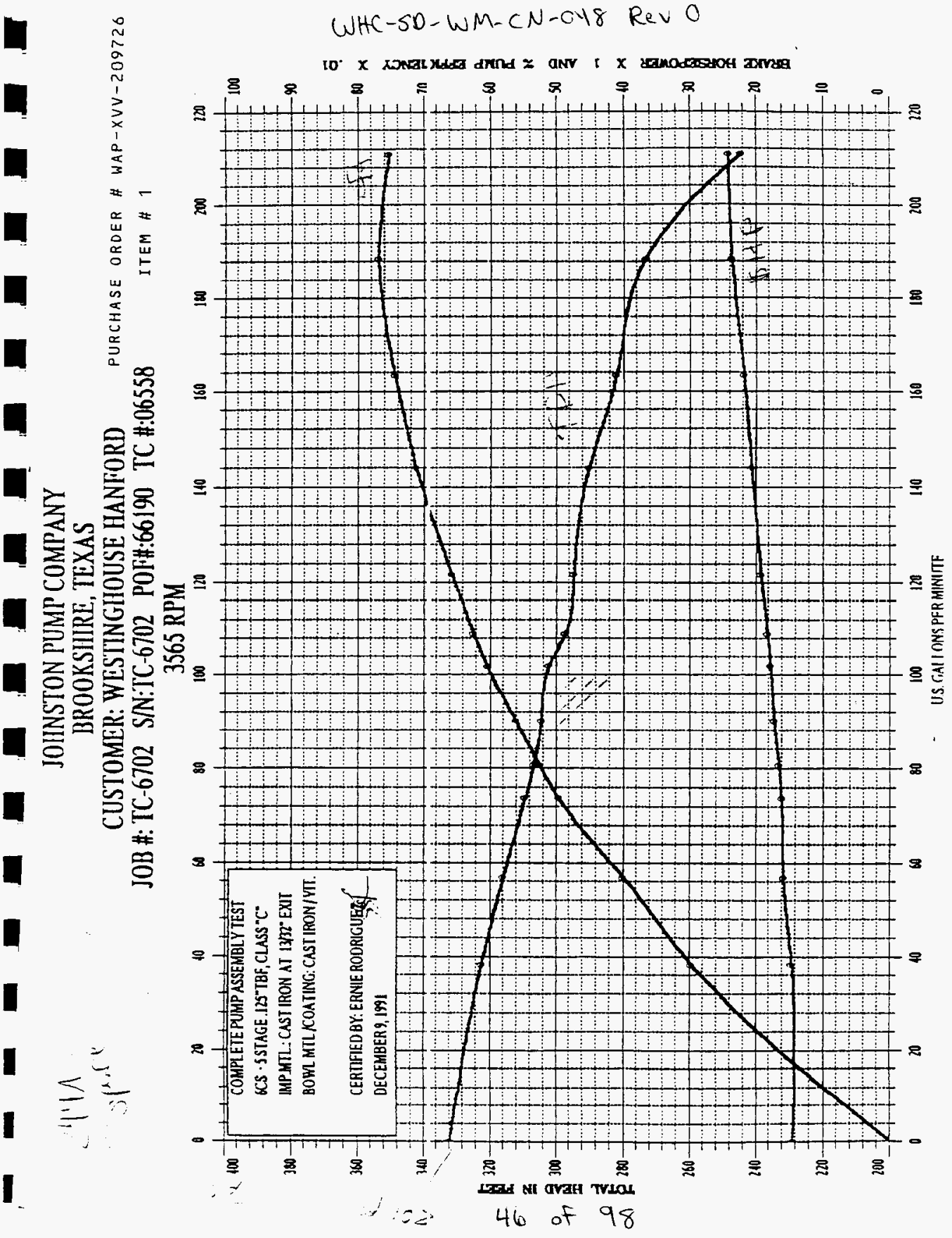


FEFIDTHFAULE DATA

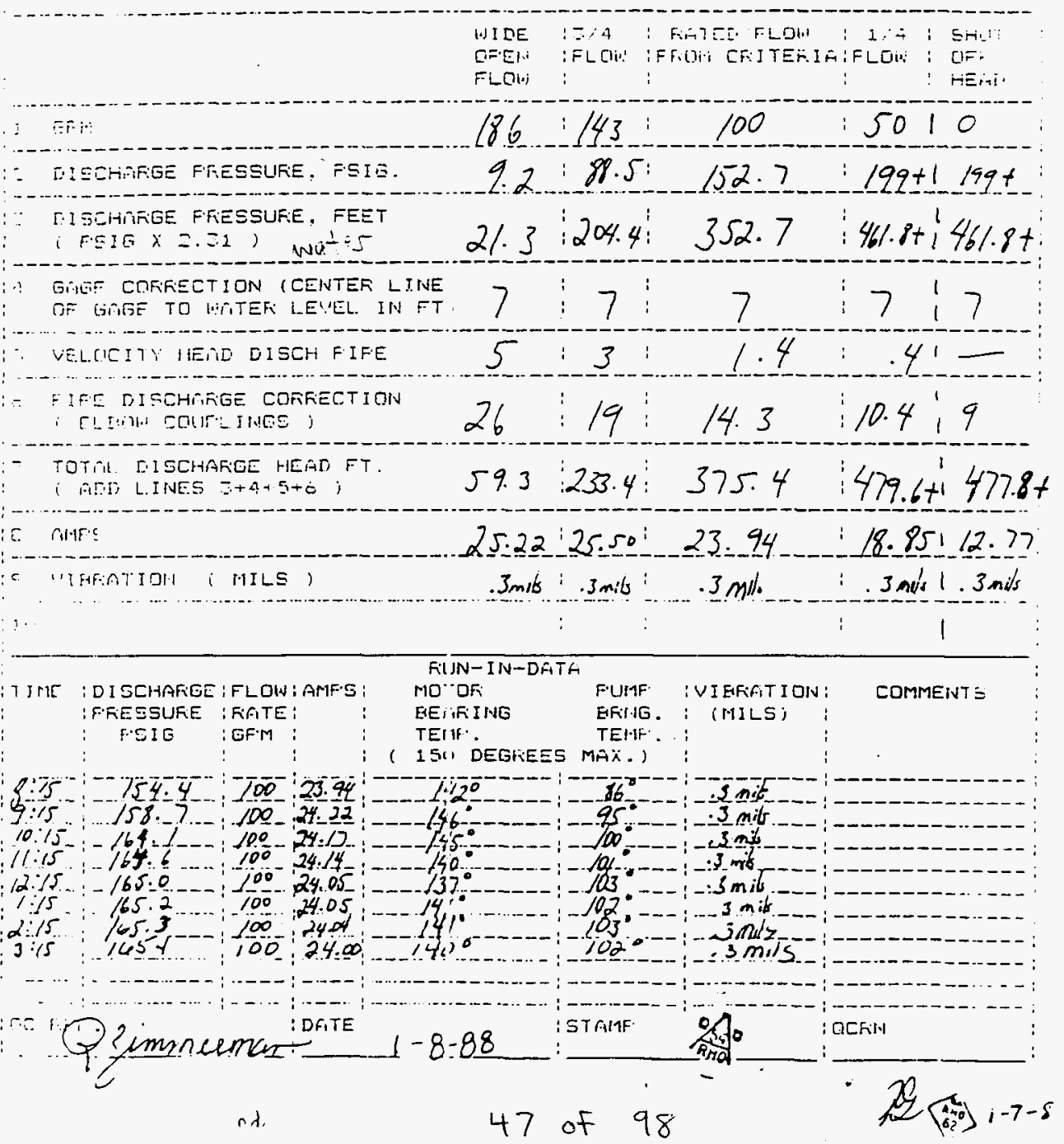




\section{WHC-SD-WM-CN-O48}

)

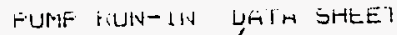

TEST FIUA-IW it I ONE

TE:T RIJ

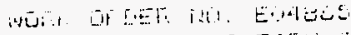

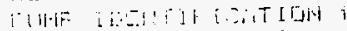

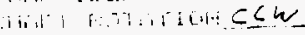
FUIF LENG
TEST SFECIFICATIUTH HOF-F-10 DISCHAFEE FIFE SIZE

FEF OORMANCE DATA

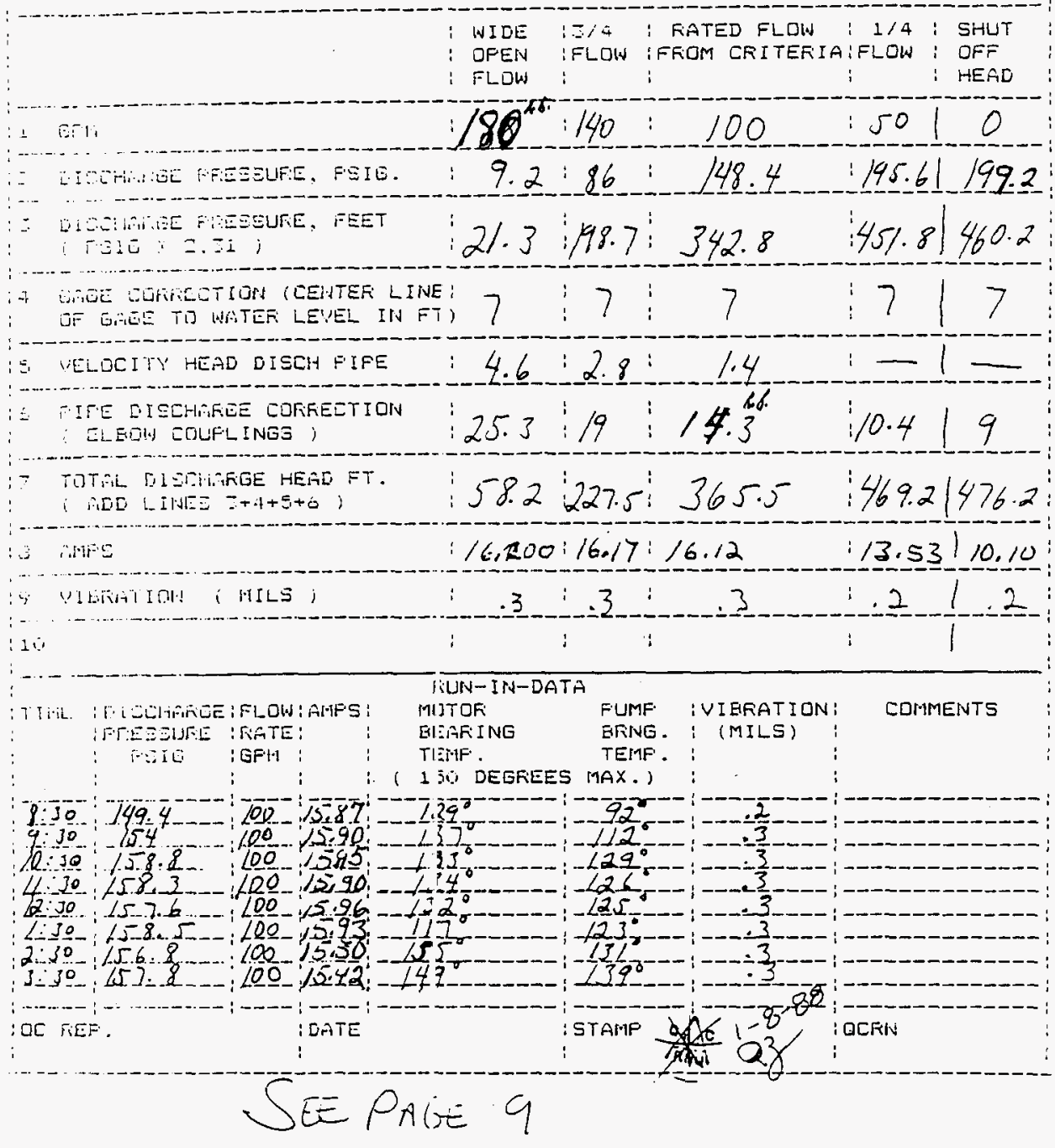

48 of 98 OC MNSPECTIOH KEEORO 34828 


\section{$\Rightarrow W H C-S D-W M-C N-O 48_{i} ! \quad \approx 4$}

ACCEPTANCE CIITERIA FOR PUMPING EQUIPMENT PAGE 7 of 7

Date of Test

Pump Sorial No. $2 / 3$ Prx -1

Worx Order No. E- $04-865$

Motor MFR.

us

Motor Full Load Rated Amps

Motor Rated Horsepower

Depth to Water Level
MFR. Pump Purchase Ordar No. E 24667

No. Stages

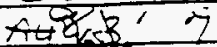

- Motor Trpe

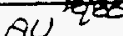

Motor TYpe Service Factor $\frac{1.15}{18-43}$
Length of Pump
Service Sp. G.

\section{TEST (:HARACTEAISTICS}

1. Test Fluid

2. S. O. Head

3. Tolat Disch. Head (Rated)

4. Capacity (AI Rared Head)

5. Test Amps

6. Test Amps $\times$ Sp. G (Service)

7. Test Voltage

8. Vibration

9. Impeiler Clearance
- Water Sp. G. 1 or Other

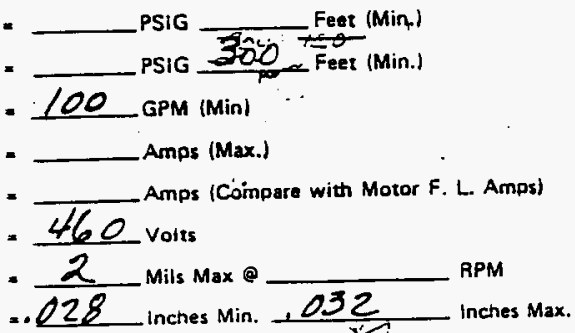

.028 inches Min. 1032 inches Max. Set at .032 s. $1-6.88$

\section{RUN-IN CHARACTERISTICS}

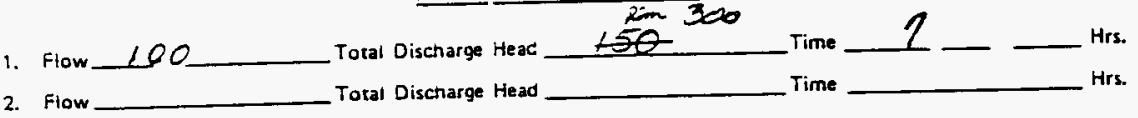

\section{SPECIAL TEST REOUIREMENTS}

Coordinate testing $w$ th Process Engineming, In b. Fister sin $3-4189$.

Remarks (Noise Level. Unusual Characteristic. etc.

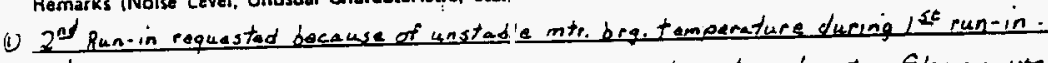

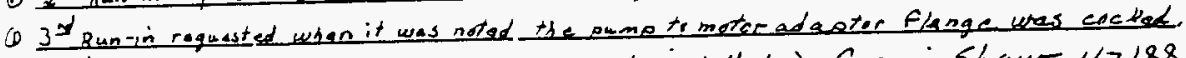

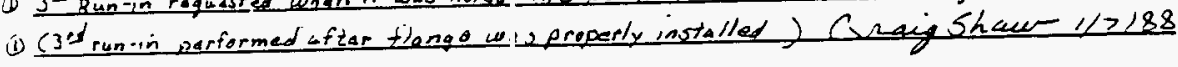

\section{QC IUSPECTIOH RECOND}

\section{Aporovat5:}

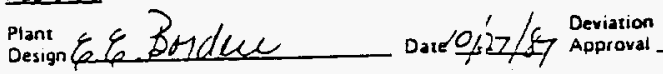

Date

Fabrication

Coptrol

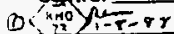

Quenty Euntol fiepremntatime
Date

9949 of 98
NOTE: Deviations from this Acoptance Criteria can oniy be approved by Plant Design. 


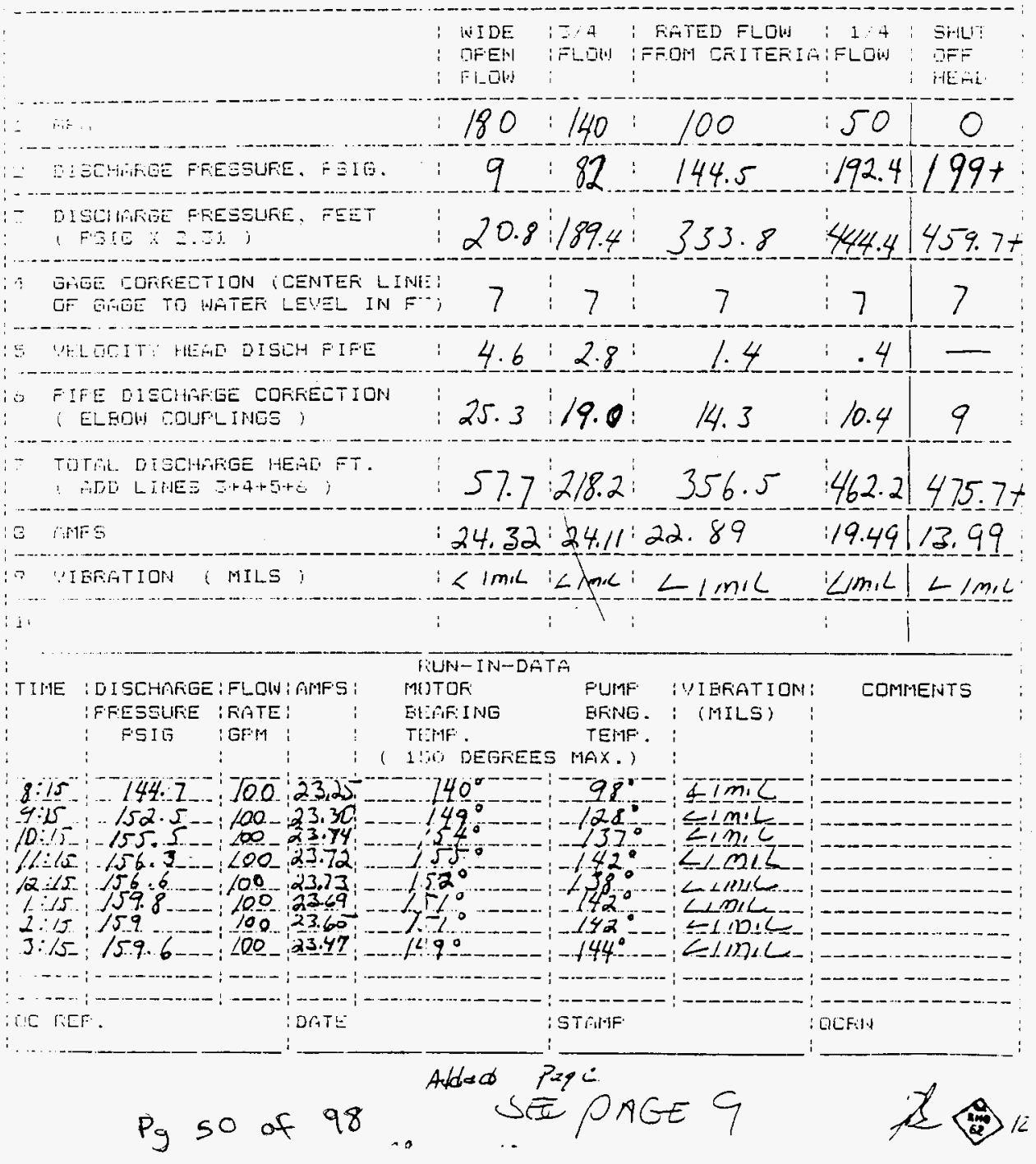


WHC-SD-WM-CN-048 REVO

PB-2 Transfer Pump Cuive (pump inside 242-A Evaporator)

51 of 98 


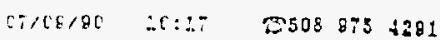

LPI INC. LAII USA

Q005:018

WH:-SD-WM-CN-048 RevO

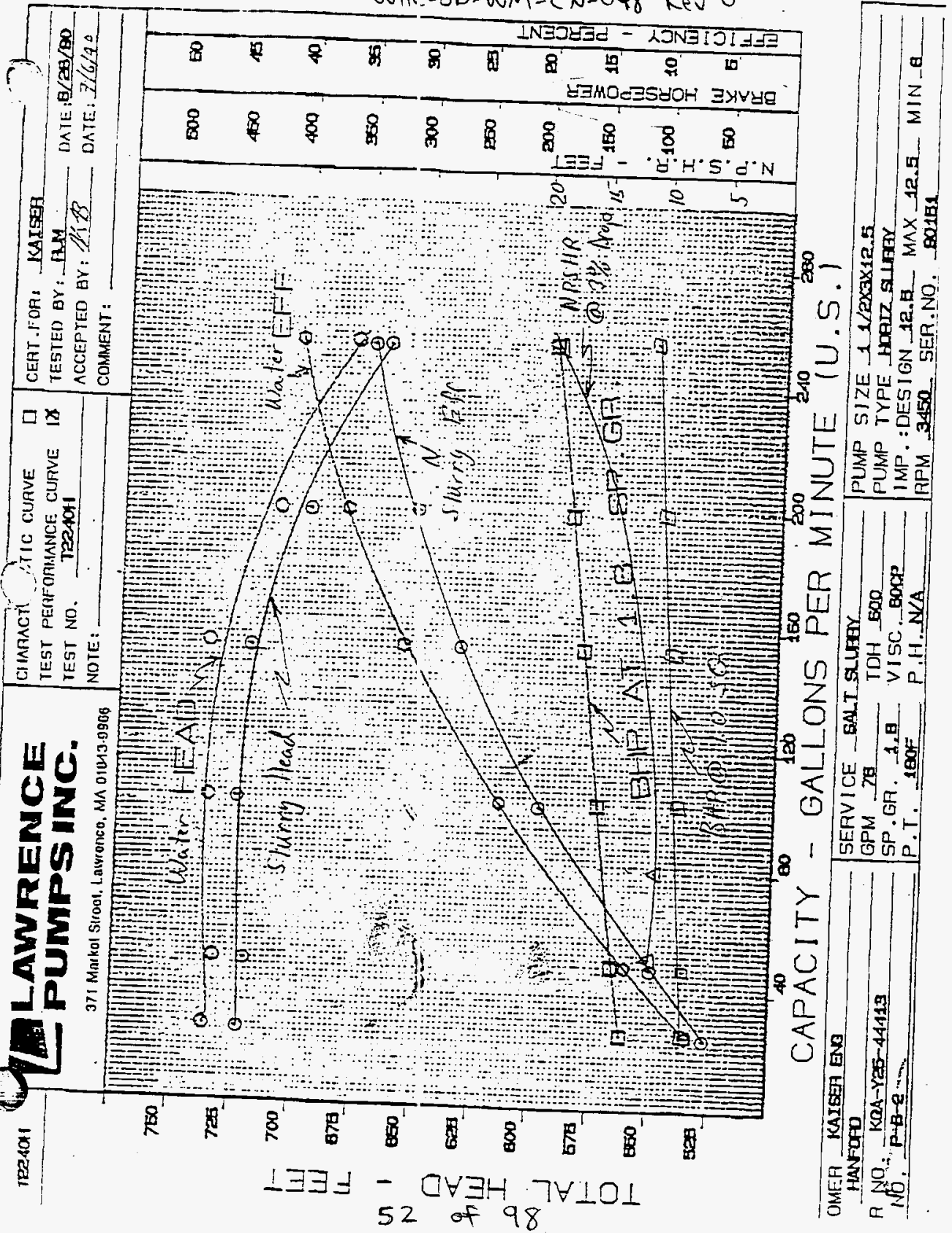




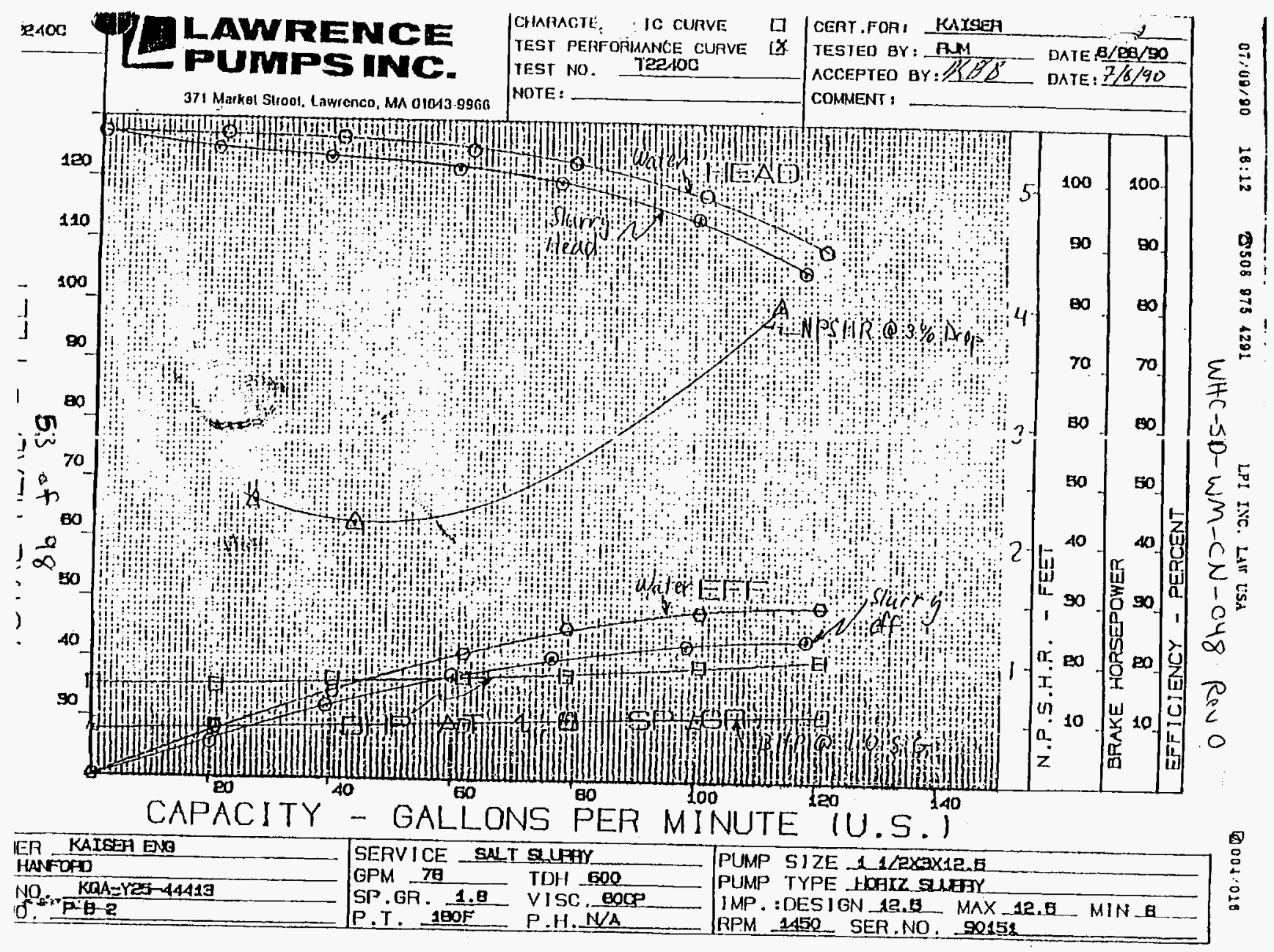


WHC-S1)-WM-CN'-O48 Rev $O$

SST Si.1twe11 Pump Curve

54 of 98 
WHC-50-WM-CN-O48 Rev O

$\rightarrow C_{0}$ रे

$\checkmark \checkmark y+\frac{1}{J}$

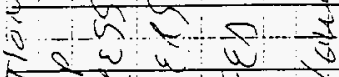

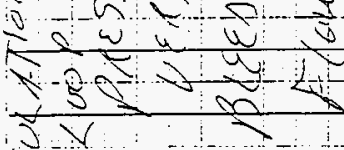

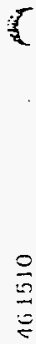

0

七 $-\cdots--$

$x$

$=\frac{1}{2}-\cdots$

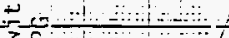

$1+1+\cdots$

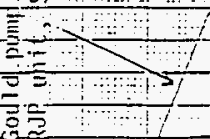

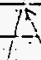

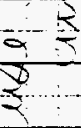

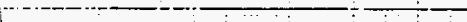
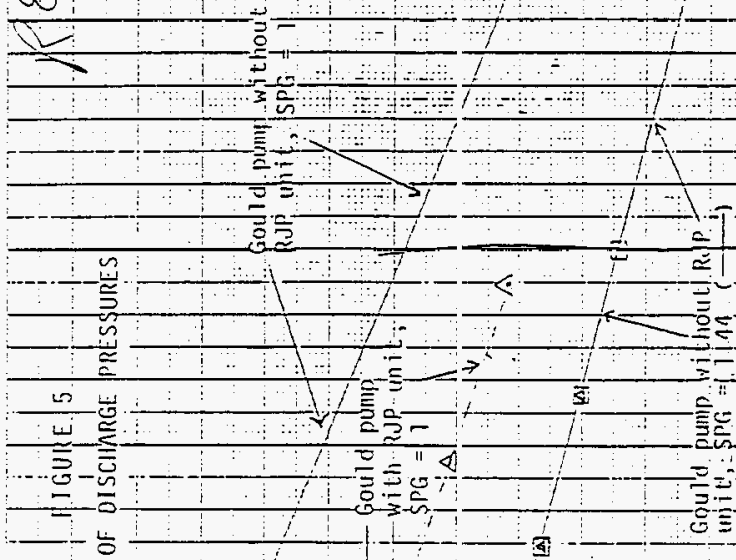

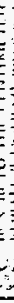

-

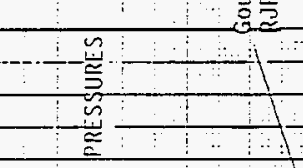

(3)

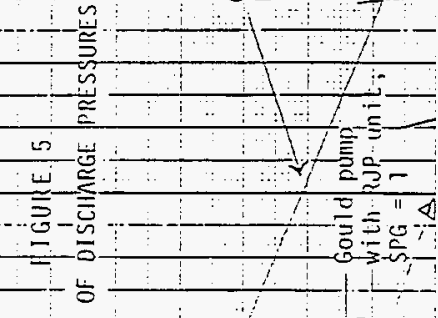

童星

$=7$
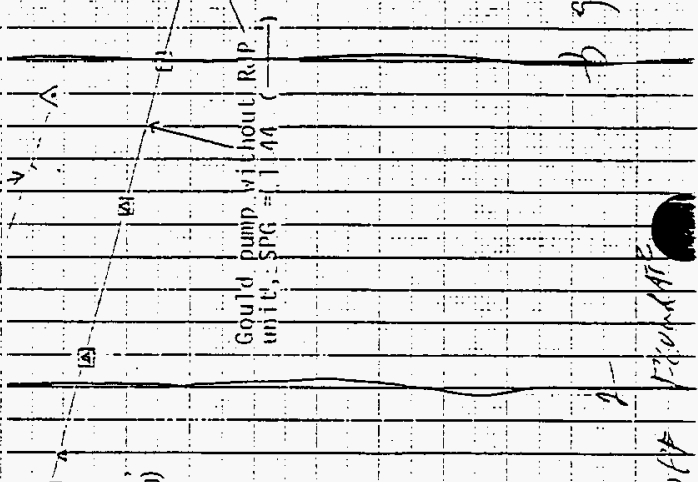

6)

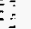

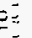

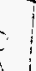

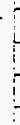

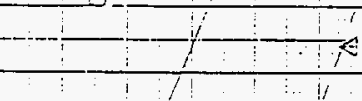

110

(a)

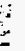
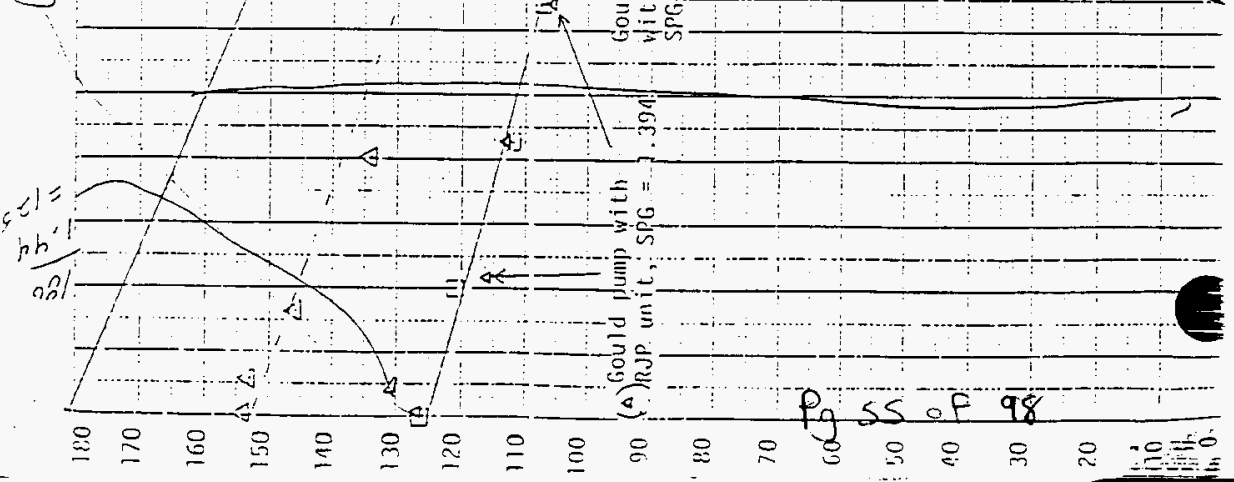


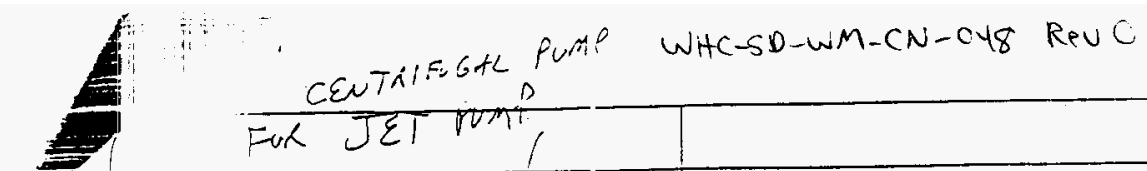


WHC-5D-WM-CN-C48 Rev $O$

SST Submersible Pump Curve

57 of 98 
WH(-S1)-WM-048 Rev $C$

\section{FLYGTE-2060 RUN-IN \\ BX-106 SETUP (4-10-95)}

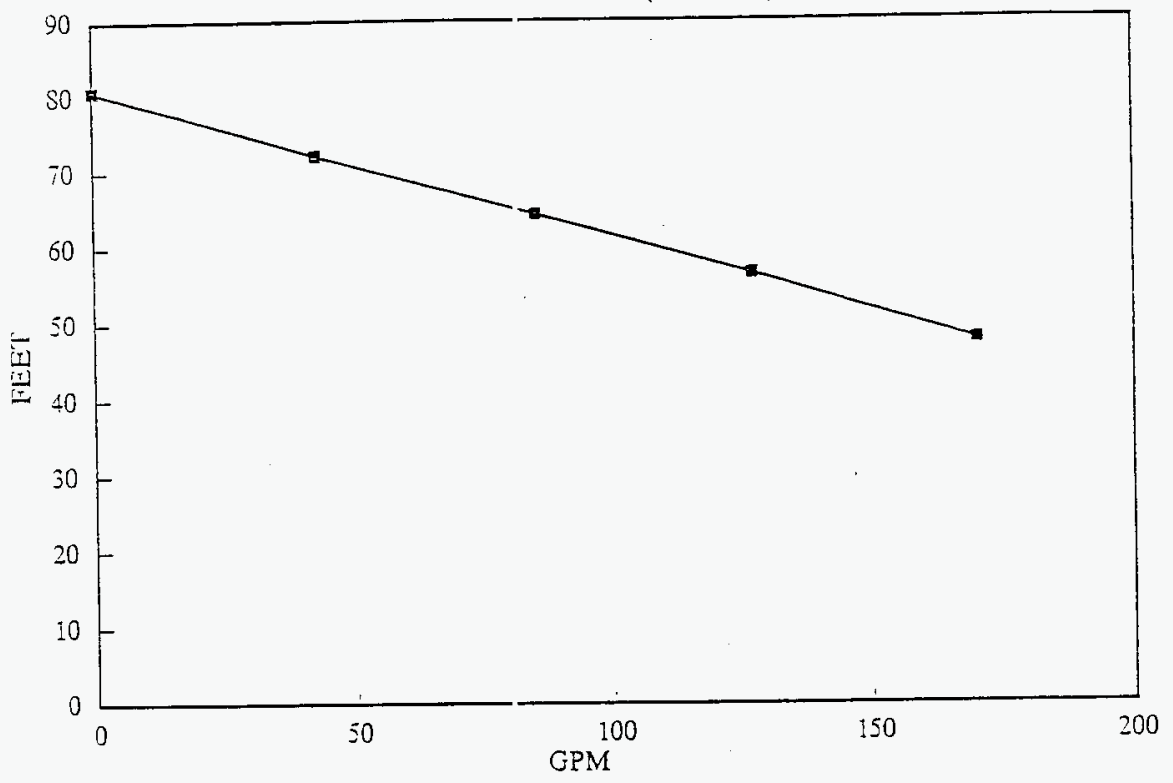

58 of 98 


$$
\text { WHC-ST1-WM-CN-O48 Rev C }
$$

204-AR Unloading :acility Transfer Pump Curve

59 of 98 
WHC-S0-WM-CN-048, KE+

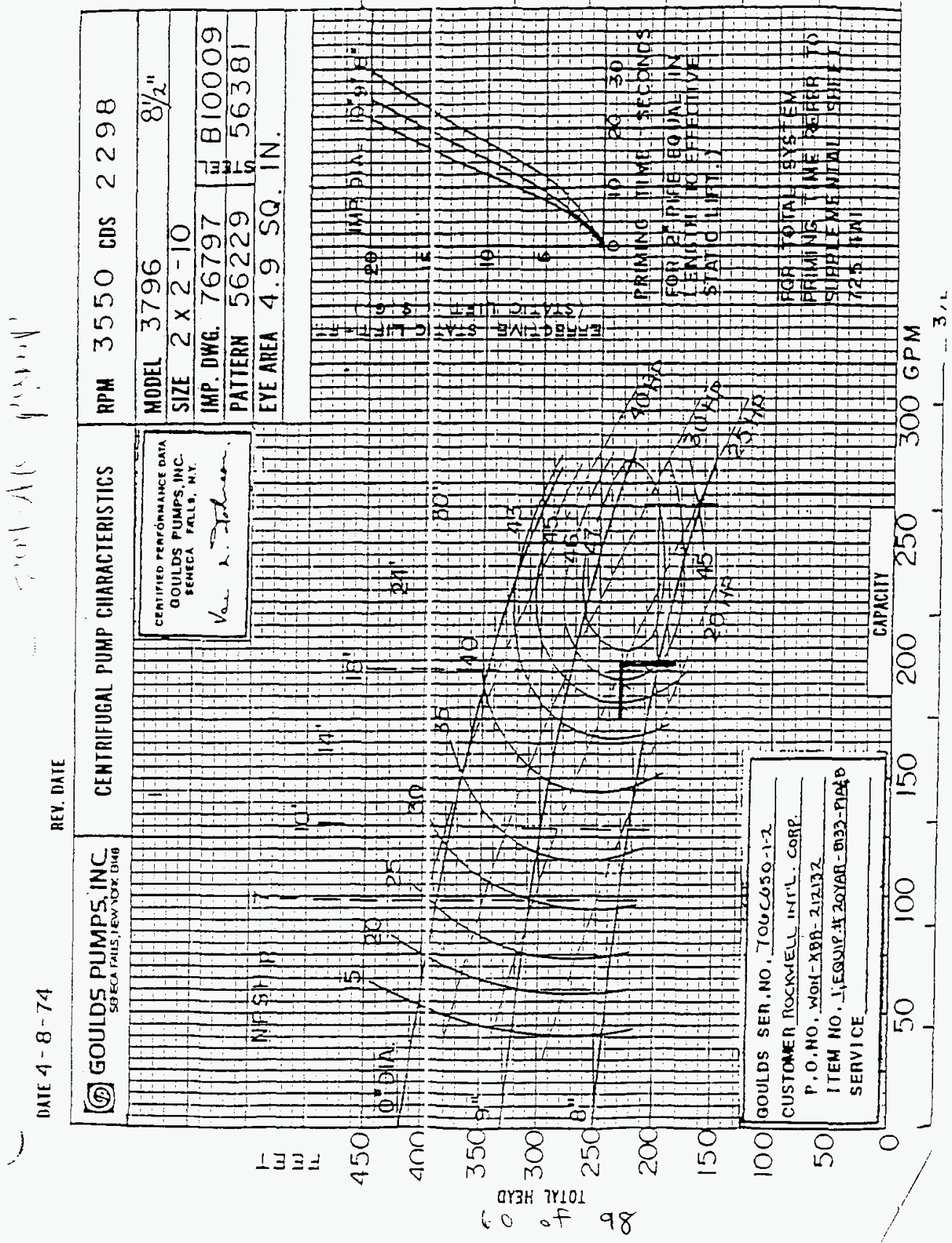


$W H C-S K-W M-C N-O 48$ Rev $O$

\section{Appendix C}

SPRAY Mo Jel Input and Output

$61 . F 98$ 
Case 1. Spray Leak Through 2 in. Sch. 40 pipe at 300 psi, Optimum Sized Crack Width, 2 in. Long Crack 
WHC-SD-IJM-CN-O48 ReV C

SPRAY Versi in 3.2

August 31,1995

Spray Leak Code

Produced by Radiological \& Toxicological Analysis

Westinghouse Hanford Company

Run Date $=07 / 29 / 96 /$

Run Time $=13: 33: 41.29$

INPUT ECHO:

c Case l: Spray at 300 psig through 2 inch crack, slit width optimized

c SPRAY Code Version 3.2 Input File

$\mathrm{C}$

c MODEL OPTIONS:

$\mathrm{C}$

c mode - program calculation mode

c $\quad=1$ for orifice leak

c $\quad=2$ for slit leak

c ifric - integer flag for friction fac:or

c $=0$ for program selection

c $=1$ for Jaminar relation

c $\quad=2$ for turbulent relation

c iopt - integer flag for flow determiliation

c $\quad=0$ for optimal diameter seari:h given initial guess diameter and $\mathrm{Re}$

$=1$ for flow based on user spıcified diameter

$=2$ for flow based on user spicified Reynold's number

mode ifric iopt

PARTICLE SIZE DISTRIBUTION TABLE PARAIIETERS:

Starting

Particle

Size Geometric Number of

(um) Step Size Inter'als

$\overline{1.00000 E+01} \quad \overline{2.00000 \mathrm{E}+00} \quad \overline{10}-$

c PARAMETER INPUT:

Initial slit

c Width or slit

c Orifice Dia. Length

(in)

(in)

Slit or

Orifice

Depth Reynold's

(in) Number

C 
$W H C-5 D-W M-C N-048$ Rev $O$

\begin{tabular}{|c|c|c|c|c|}
\hline & $1.00000 E-02$ & $2.00000 E+00$ & $1.54 \mathrm{C} 00 \mathrm{E}-01$ & $2.00000 \mathrm{E}+03$ \\
\hline 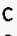 & & Absolute & & \\
\hline C & & Surface & & \\
\hline $\begin{array}{l}\text { C } \\
\text { c }\end{array}$ & & $\begin{array}{l}\text { Roughness } \\
\text { (in) }\end{array}$ & $\begin{array}{l}\text { Contraction } \\
\text { Coefficient }\end{array}$ & $\begin{array}{l}\text { Velocity } \\
\text { Coefficient }\end{array}$ \\
\hline c & Pressure & 0.00006 tube & 0.61 and & 0.98 for sharp edge orifice \\
\hline c & Differential & 0.0018 stee 1 & 1.00 & 0.98 for rounded orifice \\
\hline $\mathrm{C}$ & (psi) & 0.0102 iron & 1.00 & 0.82 for square edge orifice \\
\hline$C$ & $\overline{3.00000 E+02}$ & $\overline{1.80000 E-03}$ & $\overline{1.000} \overline{00 E+00}$ & $8.20000 \bar{E}-01$ \\
\hline$C$ & & & & \\
\hline c & Fluid & Dynamic & Respirable & RR Fitting \\
\hline c & Density & Viscosity & Diameter & Constant \\
\hline$C$ & $(g / c c)$ & (centi-poise) & $(\mu \mathrm{m})$ & \\
\hline & $\overline{1.40000 \mathrm{E}+00}$ & $1.00000 \mathrm{E}+00$ & $\overline{1.500} \overline{0 \mathrm{E}+01}$ & $\overline{2.40000 \mathrm{E}+00}$ \\
\hline 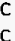 & & & & \\
\hline C & Density & Speed & & \\
\hline c & $(g / c c)$ & $(\mathrm{m} / \mathrm{s})$ & & \\
\hline & $\overline{1.22000 E-03}$ & $\overline{1.00000 E+00}$ & & \\
\hline
\end{tabular}

\section{MESSAGES:}

S1 it Mode 1

Code search for optimal equivalent diamster.

OUTPUT :

Liquid Velocity $=8.70 E+01 \mathrm{ft} / \mathrm{s} \quad 2.65 E+01 \mathrm{~m} / \mathrm{s}$

Reynolds Number $=8.44 \mathrm{E}+03$ Turbulınt Flow

Sauter Mean Diameter $=4.72 \mathrm{E}+01 \mu \mathrm{m}$

Mass Median Diameter $=6.19 \mathrm{E}+01 \mu \mathrm{m}$

Characteristic Dia. $=7.21 \mathrm{E}+01 \mu \mathrm{m}$

Optimum Slit Width $=4.48 \mathrm{E}-03$ in

Respirable Fraction $=2.28 \mathrm{E}-02$

Total Leak Rate $=2.43 \mathrm{E}+00 \mathrm{gpm}$

Respirable Leak Rate $=5.55 \mathrm{E}-02 \mathrm{gpm}$

Jet Rise $=1.32 \mathrm{E}+00 \mathrm{ft}$

1. $14 \mathrm{E}-04 \mathrm{~m}$

$1.53 \mathrm{E}-04 \mathrm{~m} 3 / \mathrm{s}$

$3.50 \mathrm{E}-06 \mathrm{~m} 3 / \mathrm{s}$

4. $02 \mathrm{E}-01 \mathrm{~m}$

$2.15 E+02 \mathrm{~g} / \mathrm{s}$

$4.90 \mathrm{E}+00 \mathrm{~g} / \mathrm{s}$

\begin{tabular}{|c|c|c|c|}
\hline $\begin{array}{l}\text { Particle } \\
\text { Diameter } \\
\text { Sections } \\
\text { (m) }\end{array}$ & $\begin{array}{l}\text { Section } \\
\text { Release } \\
\text { Rate } \\
(\mathrm{kg} / \mathrm{s})\end{array}$ & $\begin{array}{l}\text { Cumulative } \\
\text { Release } \\
\text { Rate } \\
(\mathrm{kg} / \mathrm{s})\end{array}$ & $\begin{array}{l}\text { Cumı lative } \\
\text { Percent } \\
(\%)\end{array}$ \\
\hline $\begin{array}{l}.00 \mathrm{E}-05 \\
2.00 \mathrm{E}-05 \\
4.00 \mathrm{E}-05 \\
8.00 \mathrm{E}-05 \\
1.60 \mathrm{E}-04 \\
3.20 \mathrm{E}-04 \\
6.40 \mathrm{E}-04\end{array}$ & $\begin{array}{l}1.87 \mathrm{E}-03 \\
7.80 \mathrm{E}-03 \\
3.67 \mathrm{E}-02 \\
1.09 \mathrm{E}-01 \\
5.93 \mathrm{E}-02 \\
2.46 \mathrm{E}-04 \\
0.00 \mathrm{E}+00\end{array}$ & $\begin{array}{l}1.87 \bar{E}-03 \\
9.67 \mathrm{E}-03 \\
4.64 \mathrm{E}-02 \\
1.55 \mathrm{E}-01 \\
2.15 \mathrm{E}-01 \\
2.15 \mathrm{E}-01 \\
2.15 \mathrm{E}-01\end{array}$ & $\begin{array}{r}0.87 \\
4.50 \\
i 1.58 \\
72.28 \\
59.89 \\
1 C 0.00 \\
1 C 0.00\end{array}$ \\
\hline
\end{tabular}


$W H C-5(1)-W M-C N-048$ Rev $O$

$\begin{array}{llll}1.28 \mathrm{E}-03 & 0.00 \mathrm{E}+00 & 2.15 \mathrm{E}-01 & 100.00 \\ 2.56 \mathrm{E}-03 & 0.00 \mathrm{E}+00 & 2.15 \mathrm{E}-01 & 100.00 \\ 5.12 \mathrm{E}-03 & 0.00 \mathrm{E}+00 & 2.15 \mathrm{E}-01 & 100.00\end{array}$

65 of 98 


$$
W H C-S 1)-W M-C N-048 \text { Rev } O
$$

Case 2. SST Pump Pit Spray Leak--Spray Leak Through 1 in. Schedule 40 Pipe at 85 Psig, Optimum Sized Crack Width, 2 in. Long Crack

lic of 98 
WHC-SD-NM-CN-048 Rev O

SPRAY Version 3.2

August 31, 1995

Spray Leak Code

Produced by Radiological \& Toxicological Analysis

Westinghouse Hanford Company

Run Date $=07 / 29 / 96 /$

Run Time $=13: 37: 59.16$

INPUT ECHO:

c Case 2: Spray at 85 psig through 2 i ch crack, slit width optimized

c SPRAY Code Version 3.2 Input File

$\mathrm{C}$

c MODEL OPTIONS:

$\mathrm{c}$

c mode - program calculation mode

c $\quad=1$ for orifice leak

c $\quad=2$ for slit leak

c ifric - integer flag for friction fac:or

c $=0$ for program selection

c $=1$ for laminar relation

c $\quad=2$ for turbulent relation

c iopt - integer flag for flow determination

c $\quad=0$ for optimal diameter searih given initial guess diameter and $\mathrm{Re}$

c $\quad=1$ for flow based on user spticified diameter

c $\quad=2$ for flow based on user spicified Reynold's number

C

c mode ifric iopt

200

C

c PARTICLE SIZE DISTRIBUTION TABLE PARAIIETERS:

C

c Starting

c Particle

c Size Geometric Number of

c (um) Step Size Interials

c.

$\overline{1.00000 \mathrm{E}+01} \quad \overline{2.00000 \mathrm{E}+00 \quad \overline{10}}$

$C$

c PARAMETER INPUT:

C

c Initial Slit

c Width or Si

c Orifice Dia. Length

c (in) (in)

Slit cr

Orifice

Depth Reynold's

(in) Number 


\section{WHC-SD. WM-CN-C48 Rev C}

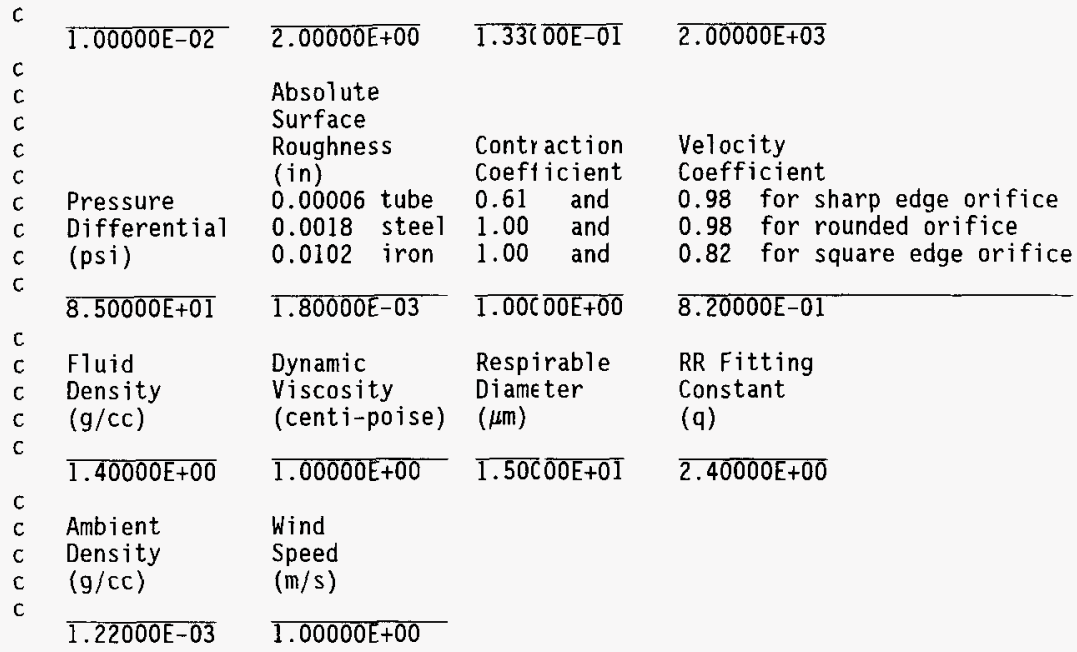

\section{MESSAGES:}

\section{Sl it Model}

Code search for optimal equivalent diameter.

OUTPUT:

Liquid Velocity $=4.65 \mathrm{E}+01 \mathrm{ft} / \mathrm{s} \quad 1.42 \mathrm{E}+01 \mathrm{~m} / \mathrm{s}$

Reynolds Number $=4.19 \mathrm{E}+03$ Turbul 2 nt Flow

Sauter Mean Diameter $=8.08 \mathrm{E}+01 \mu \mathrm{m}$

Mass Median Diameter $=1.06 \mathrm{E}+02 \mu \mathrm{m}$

Characteristic Dia. $=1.23 \mathrm{E}+02 \mu \mathrm{m}$

Opt imum S1 it Width $=4.16 \mathrm{E}-03$ in

Respirable Fraction $=6.34 \mathrm{E}-03$

Tota1 Leak Rate $=1.21 \mathrm{E}+00 \mathrm{gpm} \quad 7.61 \mathrm{E}-05 \mathrm{~m} 3 / \mathrm{s} \quad 1.07 \mathrm{E}+02 \mathrm{~g} / \mathrm{s}$

Respirable Leak Rate $=7.65 \mathrm{E}-03 \mathrm{gpm}$

Jet $\mathrm{Rise}=6.71 \mathrm{E}-01 \mathrm{ft}$

$4.82 \mathrm{E}-07 \mathrm{~m} 3 / \mathrm{s}$

$2.05 \mathrm{E}-01 \mathrm{~m}$

\begin{tabular}{|c|c|c|c|}
\hline $\begin{array}{l}\text { Particle } \\
\text { Diameter } \\
\text { Sections } \\
\text { (m) }\end{array}$ & $\begin{array}{l}\text { Section } \\
\text { Release } \\
\text { Rate } \\
(\mathrm{kg} / \mathrm{s})\end{array}$ & $\begin{array}{l}\text { Cumulative } \\
\text { Release } \\
\text { Rate } \\
(\mathrm{kg} / \mathrm{s})\end{array}$ & $\begin{array}{l}\text { Cum Jlative } \\
\text { Per:ent } \\
(\%)\end{array}$ \\
\hline $\begin{array}{l}1.00 \mathrm{E}-05 \\
2.00 \mathrm{E}-05 \\
4.00 \mathrm{E}-05 \\
8.00 \mathrm{E}-05 \\
1.60 \mathrm{E}-04 \\
3.20 \mathrm{E}-04\end{array}$ & $\begin{array}{l}2.56 \mathrm{E}-04 \\
1.09 \mathrm{E}-03 \\
5.56 \mathrm{E}-03 \\
2.48 \mathrm{E}-02 \\
5.84 \mathrm{E}-02 \\
1.65 \mathrm{E}-02\end{array}$ & $\begin{array}{l}2.56 \mathrm{E}-04 \\
1.34 \mathrm{E}-03 \\
6.90 \mathrm{E}-03 \\
3.17 \mathrm{E}-02 \\
9.01 \mathrm{E}-02 \\
1.07 \mathrm{E}-01\end{array}$ & $\begin{array}{r}0.24 \\
1.26 \\
6.47 \\
\because 9.76 \\
194.50 \\
! 19.99\end{array}$ \\
\hline
\end{tabular}




$$
\text { WHC-5(1)-WM-0y8 Revo }
$$

$\begin{array}{llll}6.40 \mathrm{E}-04 & 5.68 \mathrm{E}-06 & 1.07 \mathrm{E}-01 & 10.00 \\ 1.28 \mathrm{E}-03 & 0.00 \mathrm{E}+00 & 1.07 \mathrm{E}-01 & 10.00 \\ 2.56 \mathrm{E}-03 & 0.00 \mathrm{E}+00 & 1.07 \mathrm{E}-01 & 10.00 \\ 5.12 \mathrm{E}-03 & 0.00 \mathrm{E}+00 & 1.07 \mathrm{E}-01 & 1000\end{array}$




$$
\text { WHC-SD-WM.CN-O48 ReVO }
$$

Case 3. Spray Leak Through 2 in. Schedı le 40 Pipe at 150 Psig, Optimum Sized Crack Width 
WHC-SD-WM-CN-048 REV O

SPRAY Version 3.2

August 31, 1995

Spray Leak Code

Produced by Radiological \& Toxicologica Analysis

Westinghouse Hanford Company

Run Date $=07 / 29 / 96 /$

Run Time $=13: 44: 36.06$

\section{INPUT ECHO:}

c Case 3: Spray at 150 psig through 2 nch crack, slit width optimized

c SPRAY Code Version 3.2 Input File

$c$

c MODEL OPTIONS:

c mode - program calculation mode

c $=1$ for orifice leak

c $\quad=2$ for slit leak

c ifric - integer flag for friction factor

c $=0$ for program selection

c $=1$ for laminar relation

c $\quad=2$ for turbulent relation

c iopt - integer flag for flow determination

c $=0$ for optimal diameter search given initial guess diameter and $\operatorname{Re}$

$\mathrm{c}=1$ for flow based on user specified diameter

c $\quad=2$ for flow based on user specified Reynold's number

$\mathrm{C}$

C

mode ifric iopt

200

$C$

PARTICLE SIZE DISTRIBUTION TABLE PARAMETERS:

$c$

\section{Starting}

Particle

Size Geometric Number of

(um) Step Size Intervils

$\overline{1.00000 \mathrm{E}+01} \quad \overline{2 . \overline{00000 \bar{E}+00} \quad \overline{10}--}$

$c$

c PARAMETER INPUT:

c

c Initial Sijt

c Width or

c Orifice Dia. Length

Slit

S1 it 0 .

c (in)

(in)

Orifici?

Depth Reynold's

(in)

Number 


\section{WHC-SD-WM-CN-048 RevO}

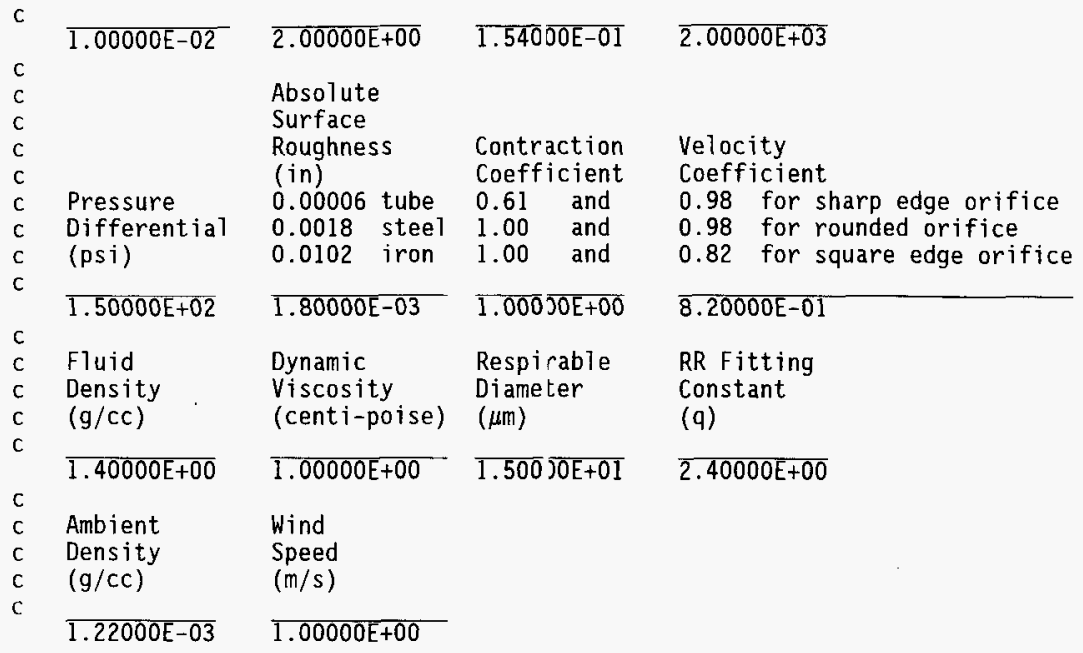

\section{MESSAGES:}

Slit Model

Code search for optimal equivalent diamıter.

OUTPUT :

Liquid Velocity $=6.13 \mathrm{E}+01 \mathrm{ft} / \mathrm{s} \quad 1.87 \mathrm{E}+01 \mathrm{~m} / \mathrm{s}$

Reynolds Number $=5.91 \mathrm{E}+03$ Turbulent Flow

Sauter Mean Diameter $=6.66 \mathrm{E}+01 \mu \mathrm{m}$

Mass Median Diameter $=8.73 \mathrm{E}+01 \mu \mathrm{m}$

Characteristic Dia. $=1.02 \mathrm{E}+02 \mu \mathrm{m}$

Optimum Slit Width $=4.46 \mathrm{E}-03$ in

Respiral'? Fraction $=1.01 \mathrm{E}-02$

Tota: Leak Rate $=1.70 \mathrm{E}+00 \mathrm{gpm} \quad 1.07 \mathrm{E}-04 \mathrm{~m} 3 / \mathrm{s} \quad 1.50 \mathrm{E}+02 \mathrm{~g} / \mathrm{s}$

Respirable Leak Rate $=1.71 \mathrm{E}-02 \mathrm{gpm} \quad 1.08 \mathrm{E}-06 \mathrm{~m} 3 / \mathrm{s} \quad 1.51 \mathrm{E}+00 \mathrm{~g} / \mathrm{s}$

Jet Rise $=9.25 \mathrm{E}-01 \mathrm{ft}$

2. $82 \mathrm{E}-01 \mathrm{~m}$

Particle Section Cumulative

Diameter Release Release Cumllative

Sections Rate Rate Percent

(m) $\quad(\mathrm{kg} / \mathrm{s}) \quad(\mathrm{kg} / \mathrm{s}) \quad(\%)$

$\begin{array}{llllr}\overline{1.00 \mathrm{E}-05} & 5.73 \mathrm{E}-04 & 5.73 \mathrm{E}-04 & & \\ 2.00 \mathrm{E}-05 & 2.43 \mathrm{E}-03 & 3.00 \mathrm{E}-03 & & 1.99 \\ 4.00 \mathrm{E}-05 & 1.22 \mathrm{E}-02 & 1.52 \mathrm{E}-02 & & 10.09 \\ 8.00 \mathrm{E}-05 & 4.95 \mathrm{E}-02 & 6.46 \mathrm{E}-02 & & 42.96 \\ 1.60 \mathrm{E}-04 & 7.81 \mathrm{E}-02 & 1.43 \mathrm{E}-01 & & 54.83 \\ 3.20 \mathrm{E}-04 & 7.78 \mathrm{E}-03 & 1.50 \mathrm{E}-01 & & 100.00\end{array}$




$$
\text { WHC-SO-NM-CN-OY8 REV O }
$$

$\begin{array}{llll}6.40 \mathrm{E}-04 & 2.98 \mathrm{E}-08 & 1.50 \mathrm{E}-01 & 100.00 \\ 1.28 \mathrm{E}-03 & 0.00 \mathrm{E}+00 & 1.50 \mathrm{E}-01 & 100.00 \\ 2.56 \mathrm{E}-03 & 0.00 \mathrm{E}+00 & 1.50 \mathrm{E}-01 & 100.00 \\ 5.12 \mathrm{E}-03 & 0.00 \mathrm{E}+00 & 1.50 \mathrm{E}-01 & 100.00\end{array}$

$$
73 \text { of } 98
$$




$$
\text { WHC-SD-VIM-CN-O48 ReV C }
$$

Case 4. Spray Leak Through 2 in. Sch. 4J Pipe at 50 Psig, Optimum Crack Width, 2 in. Crack Length 
WHC-SD-WM-CN-0.18 Rev O

SPRAY Version 3.2

August 31,1995

Spray Leak Code

Produced by Radiological \& Toxicological Analysis

Westinghouse Hanford Company

Run Date $=07 / 29 / 96 /$

Run Time $=13: 48: 43.44$

INPUT ECHO:

c Case 4: Spray at 50 psig through 2 inch crack, sch. 40 pipe, optimum slit

c SPRAY Code Version 3.2 Input File

$\mathrm{C}$

c MODEL OPTIONS:

C

c mode - program calculation mode

c $\quad=1$ for orifice leak

c $\quad=2$ for slit leak

c ifric - integer flag for friction factor

= 0 for program selection

= 1 for laminar relation

$=2$ for turbulent relation

iopt - integer flag for flow determiation

$=0$ for optimal diameter searzh given initial guess diameter and Re

$=1$ for flow based on user spacified diameter

$=2$ for flow based on user spzcified Reynold's number

mode ifric iopt

200

$\mathrm{C}$

c PARTICLE SIZE DISTRIBUTION TABLE PARA AETERS:

C

C Starting

c Particle

c Size Geometric Numbe " of

c (um) Step Size Interials

$\mathrm{C}$

\section{$\overline{1.00000 E+01} \quad \overline{2.00000 E+00} \quad \overline{10}$}

C

c PARAMETER INPUT:

C

c Initial slit

c Width or

c Orifice Dia.

c (in)

Slit

Length

(in)
S1it isr

Orifi:e

Depth Reynold's

(in) Number 
WHC-SN-WM-CN-O48 Rev O

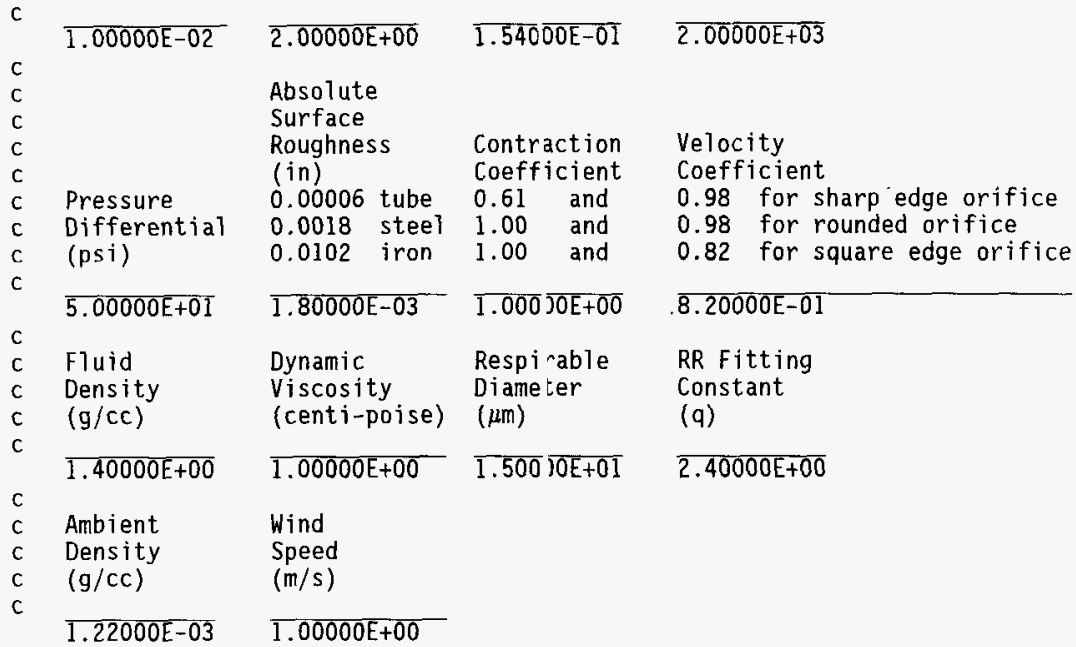

\section{MESSAGES:}

Sl it Model

Code search for optimal equivalent diameter.

\section{OUTPUT :}

Liquid Velocity $=3.54 \mathrm{E}+01 \mathrm{ft} / \mathrm{s} \quad 1.08 \mathrm{E}+01 \mathrm{~m} / \mathrm{s}$

Reynolds Number $=3.43 \mathrm{E}+03$ Critica $1 \mathrm{Flow}$

Sauter Mean Diameter $=1.16 \mathrm{E}+02 \mu \mathrm{m}$

Mass Median Diameter $=1.52 \mathrm{E}+02 \mu \mathrm{m}$

Characteristic Dia. $=1.77 \mathrm{E}+02 \mu \mathrm{m}$

Optimum Slit width $=4.48 \mathrm{E}-03$ in

Respirab7e Fraction $=2.66 \mathrm{E}-03$

Total Leak Rate $=9.88 \mathrm{E}-01 \mathrm{gpm}$

Respirable Leak Rate $=2.63 \mathrm{E}-03 \mathrm{gpm}$

Jet Rise $=5.36 \mathrm{E}-01 \mathrm{ft}$

1. $14 \mathrm{E}-04 \mathrm{~m}$

6. $24 \mathrm{E}-05 \mathrm{~m} 3 / \mathrm{s}$

1. $66 \mathrm{E}-07 \mathrm{~m} 3 / \mathrm{s}$

$1.63 \mathrm{E}-01 \mathrm{~m}$

$8.73 \mathrm{E}+01 \mathrm{~g} / \mathrm{s}$

$2.32 \mathrm{E}-01 \mathrm{~g} / \mathrm{s}$

\begin{tabular}{|c|c|c|c|}
\hline $\begin{array}{l}\text { Particle } \\
\text { Diameter } \\
\text { Sections } \\
(m)\end{array}$ & $\begin{array}{l}\text { Section } \\
\text { Release } \\
\text { Rate } \\
(\mathrm{kg} / \mathrm{s})\end{array}$ & $\begin{array}{l}\text { Cumulative } \\
\text { Release } \\
\text { Rate } \\
(\mathrm{kg} / \mathrm{s})\end{array}$ & $\begin{array}{l}\text { Cumulative } \\
\text { Percent } \\
(\%)\end{array}$ \\
\hline $\begin{array}{l}1.00 \mathrm{E}-05 \\
2.00 \mathrm{E}-05 \\
4.00 \mathrm{E}-05 \\
8.00 \mathrm{E}-05 \\
1.60 \mathrm{E}-04 \\
3.20 \mathrm{E}-04\end{array}$ & $\begin{array}{l}8.78 E-05 \\
3.75 E-04 \\
1.95 E-03 \\
9.59 E-03 \\
3.53 E-02 \\
3.86 E-02\end{array}$ & $\begin{array}{l}8.78 \mathrm{E}-05 \\
4.62 \mathrm{E}-04 \\
2.41 \mathrm{E}-03 \\
1.20 \mathrm{E}-02 \\
4.73 \mathrm{E}-02 \\
8.59 \mathrm{E}-02\end{array}$ & $\begin{array}{r}3.10 \\
3.53 \\
3.76 \\
13.75 \\
51.19 \\
93.38\end{array}$ \\
\hline
\end{tabular}


WHC-SO-WM-CN-CY8 Rev C

$\begin{array}{llll}6.40 \mathrm{E}-04 & 1.42 \mathrm{E}-03 & 8.73 \mathrm{E}-02 & 130.00 \\ 1.28 \mathrm{E}-03 & 0.00 \mathrm{E}+00 & 8.73 \mathrm{E}-02 & 130.00 \\ 2.56 \mathrm{E}-03 & 0.00 \mathrm{E}+00 & 8.73 \mathrm{E}-02 & 130.00 \\ 5.12 \mathrm{E}-03 & 0.00 \mathrm{E}+00 & 8.73 \mathrm{E}-02 & 100.00\end{array}$

77 of 98 
Case 5. Spray Leak Through 2 in. Sch. 70 Pipe at $300 \mathrm{psig,} 0.01$ in Crack Width, 2 in. Long Crack. 
SPRAY Version 3.2

August 31,1995

Spray Leak Code

Produced by Radiological \& Toxicological Analysis

Westinghouse Hanford Company

Run Date $=05 / 30 / 96 /$

Run Time $=15: 44: 56.01$

INPUT ECHO:

c Case 5: 300 psig, 0.01 in wide crack

c SPRAY Code Version 3.2 Input Fite

$\mathrm{C}$

C MODEL OPTIONS:

c

C mode - program calculation mode

$\mathrm{c}=1$ for orifice leak

c $\quad=2$ for slit leak

c ifric - integer flag for friction fac:or

$=0$ for program selection

$=1$ for laminar relation

$=2$ for turbulent relation

iopt - integer flag for flow determiliation

$=0$ for optimal diameter search given initial guess diameter and $\mathrm{Re}$

$=1$ for flow based on user spucified diameter

$=2$ for flow based on user specified Reynold's number

mode ifric iopt

$\begin{array}{lll}2 & 0 & 1\end{array}$

C

PARTICLE SIZE DISTRIBUTION TABLE PARANETERS:

c

C

Starting

Particle

Size Geometric Number of

(um) Step Size Intervals

$\overline{1.00000 \mathrm{E}+0 \mathrm{I}} \overline{2.00000 \mathrm{E}+00} \quad \overline{10}$

$c$

c PARAMETER INPUT:

c Initial slit

c Width or slit

c Orifice Dia. Length

c (in)

(in)

Slit or

Orifice

Depth Reynold's

(in) Number 
WHC-ST-WM-CN-048 RevC

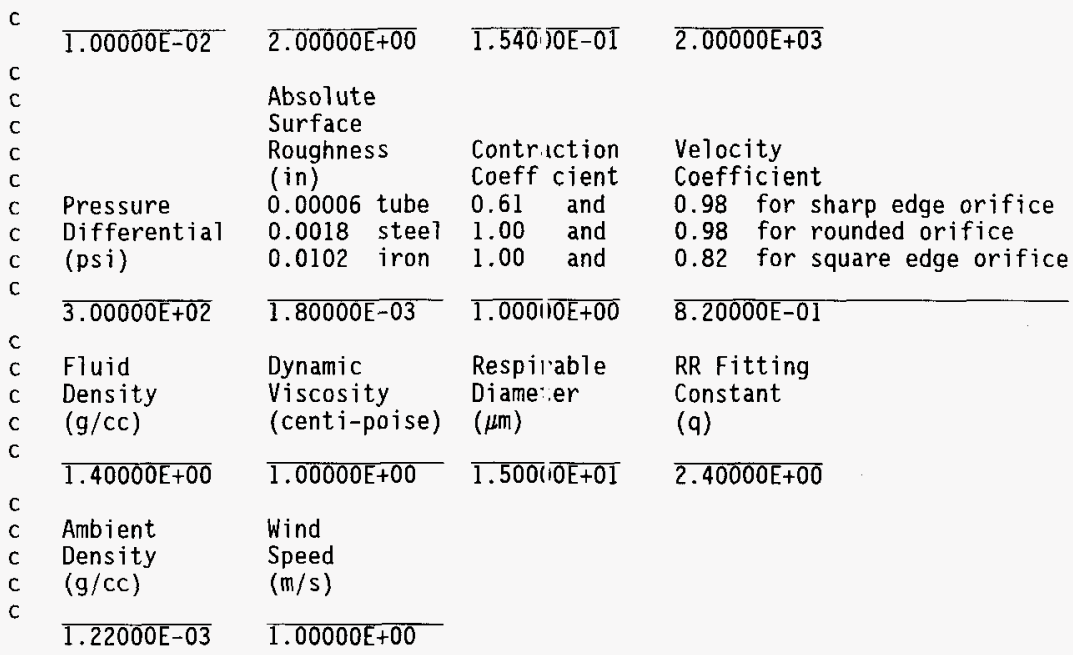

\section{MESSAGES:}

Slit Mode1

User specified orifice diameter or slit width.

OUTPUT:

Liquid Velocity $=1.19 \mathrm{E}+02 \mathrm{ft} / \mathrm{s} \quad 3.64 \mathrm{E}+01 \mathrm{~m} / \mathrm{s}$

Reynolds Number $=2.57 \mathrm{E}+04$ Turbulent Flow

Sauter Mean Diameter $=8.99 \mathrm{E}+01 \mu \mathrm{m}$

Mass Median Diameter $=1.18 \mathrm{E}+02 \mu \mathrm{m}$

Characteristic Dia. $=1.37 \mathrm{E}+02 \mu \mathrm{m}$

Respirable Fraction $=4.91 \mathrm{E}-03$

TotaT Leak Rate $=7.44 \mathrm{E}+00 \mathrm{gpm}$

Respirable Leak Rate $=3.65 \mathrm{E}-02 \mathrm{gpm}$

Jet Rise $=3.08 \mathrm{E}+00 \mathrm{ft}$

4. $69 \mathrm{E}-04 \mathrm{~m} 3 / \mathrm{s}$

2. $30 \mathrm{E}-06 \mathrm{~m} 3 / \mathrm{s}$

9.39E-01 m

$6.57 \mathrm{E}+02 \mathrm{~g} / \mathrm{s}$

$3.23 \mathrm{E}+00 \mathrm{~g} / \mathrm{s}$

\begin{tabular}{|c|c|c|c|}
\hline $\begin{array}{l}\text { Particle } \\
\text { Diameter } \\
\text { Sections } \\
\text { (m) }\end{array}$ & $\begin{array}{l}\text { Section } \\
\text { Release } \\
\text { Rate } \\
(\mathrm{kg} / \mathrm{s})\end{array}$ & $\begin{array}{l}\text { Cumulative } \\
\text { Release } \\
\text { Rate } \\
(\mathrm{kg} / \mathrm{s})\end{array}$ & $\begin{array}{l}\text { Cumulative } \\
\text { Percent } \\
(\%)\end{array}$ \\
\hline $\begin{array}{l}1.00 \mathrm{E}-05 \\
2.00 \mathrm{E}-05 \\
4.00 \mathrm{E}-05 \\
8.00 \mathrm{E}-05 \\
1.60 \mathrm{E}-04 \\
3.20 \mathrm{E}-04 \\
6.40 \mathrm{E}-04\end{array}$ & $\begin{array}{l}1.22 \mathrm{E}-03 \\
5.20 \mathrm{E}-03 \\
2.68 \mathrm{E}-02 \\
1.24 \mathrm{E}-01 \\
3.45 \mathrm{E}-01 \\
1.55 \mathrm{E}-01 \\
3.22 \mathrm{E}-04\end{array}$ & $\begin{array}{l}1.22 \mathrm{E}-03 \\
6.42 \mathrm{E}-03 \\
3.32 \mathrm{E}-02 \\
1.57 \mathrm{E}-01 \\
5.02 \mathrm{E}-01 \\
6.57 \mathrm{E}-01 \\
6.57 \mathrm{E}-01\end{array}$ & $\begin{array}{r}3.19 \\
3.98 \\
3.05 \\
23.93 \\
73.39 \\
93.95 \\
103.00\end{array}$ \\
\hline
\end{tabular}


$W H C-5 D-W M-C N-048$ Rev C

$\begin{array}{llll}1.28 \mathrm{E}-03 & 0.00 \mathrm{E}+00 & 6.57 \mathrm{E}-01 & 110.00 \\ 2.56 \mathrm{E}-03 & 0.00 \mathrm{E}+00 & 6.57 \mathrm{E}-01 & 110.00 \\ 5.12 \mathrm{E}-03 & 0.00 \mathrm{E}+00 & 6.57 \mathrm{E}-01 & 110.00\end{array}$

81 -f 98 


$$
\text { WHC-SD-NM-CN-C48 Rev C }
$$

Case 6: Spray Leak Through 2 in. Schedule 40 Pipe, 2 in. Long Crack, 0.1 in. Crack Width. 
WHC-SD-WM-CN-O48 ReVC

SPRAY Version 3.2

August 31,1995

Spray Leak Code

Produced by Radiological \& Toxicological Analysis

Westinghouse Hanford Company

Run Date $=05 / 30 / 96 /$

Run Time $=15: 48: 15.01$

INPUT ECHO:

c Case $6.300 \mathrm{psig}, 0.1$ in wide crack

c SPRAY Code Version 3.2 Input File

$\mathrm{C}$

c MODEL OPTIONS:

$\mathrm{c}$

c mode - program calculation mode

$\mathrm{c} \quad=1$ for orifice leak

c $\quad=2$ for slit leak

c ifric - integer flag for friction fac:or

c $=0$ for program selection

c $\quad=1$ for laminar relation

c $\quad=2$ for turbulent relation

c iopt - integer flag for flow determination

$\mathrm{c} \quad=0$ for optimal diameter searih given initial guess diameter and $\operatorname{Re}$

c $\quad=1$ for flow based on user specified diameter

c $\quad=2$ for flow based on user specified Reynold's number

$\mathrm{c}$

c mode ifric iopt

2001

$\mathrm{C}$

c PARTICLE SIZE DISTRIBUTION TABLE PARANIETERS:

$\mathrm{C}$

C Starting

c Particle

c Size Geometric Number of

c (um) Step Size Interials

c

$\overline{1.00000 E+01} \quad \overline{2.00000 E+00} \quad \overline{10}$

$C$

c PARAMETER INPUT:

$\mathrm{C}$

C Initial slit

c Width or slit

c Orifice Dia. Length

Slit cr

Orifice

Depth

Reynold's

83 of 98 


\section{$W H C-S D-W M-C N-C 48$ ReV $O$}

\begin{tabular}{|c|c|c|c|c|}
\hline$c$ & (in) & (in) & (in) & Number \\
\hline & $\overline{1.000 \overline{00 E}-01}$ & $\overline{2.00000 \mathrm{E}+00}$ & $\overline{1.5400} \overline{0 E-01}$ & $2.00000 \mathrm{E}+03$ \\
\hline$r$ & & $\begin{array}{l}\text { Absolute } \\
\text { Surface } \\
\text { Rougness }\end{array}$ & Contriction & \\
\hline$C$ & & $\begin{array}{l}\text { Roughness } \\
\text { (in) }\end{array}$ & $\begin{array}{l}\text { Contriction } \\
\text { Coefficient }\end{array}$ & $\begin{array}{l}\text { Velocity } \\
\text { Coefficient }\end{array}$ \\
\hline c & Pressure & 0.00006 tube & 0.61 and & 0.98 for sharp edge orifice \\
\hline$C$ & $\begin{array}{l}\text { Differential } \\
\text { (psi) }\end{array}$ & $\begin{array}{ll}0.0018 & \text { stee } \\
0.0102 & \text { iron }\end{array}$ & $\begin{array}{l}1.00 \text { and } \\
1.00 \text { and }\end{array}$ & $\begin{array}{l}0.98 \text { for rounded orifice } \\
0.82 \text { for square edge orifice }\end{array}$ \\
\hline$c$ & $\overline{3.00000 E+02}$ & $1 . \overline{80000 E-03}$ & $\overline{1.000 C \overline{0 E+00}}$ & $8.20000 E-01$ \\
\hline 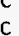 & & & & \\
\hline$c$ & $\begin{array}{l}\text { Density } \\
(g / c c)\end{array}$ & $\begin{array}{l}\text { Viscosity } \\
\text { (centi-poise) }\end{array}$ & $\begin{array}{l}\text { Diameter } \\
(\mu \mathrm{m})\end{array}$ & $\begin{array}{l}\text { Constant } \\
\text { (q) }\end{array}$ \\
\hline & $\overline{1.40000 E+00}$ & $1.00000 E+00$ & $\overline{1.500 \overline{0 E}+01}$ & $2.40000 \mathrm{E}+00$ \\
\hline c & $\begin{array}{l}\text { Ambient } \\
\text { Density } \\
(\mathrm{g} / \mathrm{cc})\end{array}$ & $\begin{array}{l}\text { Wind } \\
\text { Speed } \\
(\mathrm{m} / \mathrm{s})\end{array}$ & & \\
\hline & $1.22000 E-03$ & $\overline{1.00000 E+00}$ & & \\
\hline
\end{tabular}

\section{MESSAGES:}

Slit Model

User specified orifice diameter or slit vidth.

OUTPUT:

Liquid Velocity $=1.45 \mathrm{E}+02 \mathrm{ft} / \mathrm{s} \quad 4.41 \mathrm{E}+01 \mathrm{~m} / \mathrm{s}$

Reynolds Number $=2.99 E+05$ Turbule it Flow

Sauter Mean Diameter $=1.11 \mathrm{E}+03 \mu \mathrm{m}$

Mass Median Diameter $=1.46 \mathrm{E}+03 \mu \mathrm{m}$

Characteristic Dia. $=1.70 \mathrm{E}+03 \mu \mathrm{m}$

Respirable Fraction $=1.17 \mathrm{E}-05$

Total Leak Rate $=9.03 \mathrm{E}+01 \mathrm{gpm}$

Respirable Leak Rate $=1.06 \mathrm{E}-03 \mathrm{gpm}$

Jet Rise $=1.69 \mathrm{E}+01 \mathrm{ft}$

$5.70 \mathrm{E}-03 \mathrm{~m} 3 / \mathrm{s}$

$6.68 \mathrm{E}-08 \mathrm{m3} / \mathrm{s}$

$5.14 \mathrm{E}+00 \mathrm{~m}$
$7.98 \mathrm{E}+03 \mathrm{~g} / \mathrm{s}$

$9.35 \mathrm{E}-02 \mathrm{~g} / \mathrm{s}$

\begin{tabular}{|c|c|c|c|}
\hline $\begin{array}{l}\text { Particle } \\
\text { Diameter } \\
\text { Sections } \\
\text { (m) }\end{array}$ & $\begin{array}{l}\text { Section } \\
\text { Release } \\
\text { Rate } \\
(\mathrm{kg} / \mathrm{s})\end{array}$ & $\begin{array}{l}\text { Cumulative } \\
\text { Release } \\
\text { Rate } \\
\text { (kg/s) }\end{array}$ & $\begin{array}{l}\text { Cumu ative } \\
\text { Percunt } \\
(\%)\end{array}$ \\
\hline $\begin{array}{l}1.00 \mathrm{E}-05 \\
2.00 \mathrm{E}-05 \\
4.00 \mathrm{E}-05 \\
8.00 \mathrm{E}-05 \\
1.60 \mathrm{E}-04 \\
3.20 \mathrm{E}-04\end{array}$ & $\begin{array}{l}3.53 \mathrm{E}-05 \\
1.51 \mathrm{E}-04 \\
7.98 \mathrm{E}-04 \\
4.21 \mathrm{E}-03 \\
2.22 \mathrm{E}-02 \\
1.16 \mathrm{E}-01\end{array}$ & $\begin{array}{l}3.53 \mathrm{E}-05 \\
1.87 \mathrm{E}-04 \\
9.85 \mathrm{E}-04 \\
5.20 \mathrm{E}-03 \\
2.74 \mathrm{E}-02 \\
1.43 \mathrm{E}-01\end{array}$ & $\begin{array}{l}1.00 \\
1.00 \\
1.01 \\
1.07 \\
1.34 \\
] .80\end{array}$ \\
\hline
\end{tabular}




$$
\text { WHC-SOI-WM-CN-OY8 ReV O }
$$

$\begin{array}{rrrr}6.40 \mathrm{E}-04 & 5.85 \mathrm{E}-01 & 7.29 \mathrm{E}-01 & 9.14 \\ 1.28 \mathrm{E}-03 & 2.44 \mathrm{E}+00 & 3.17 \mathrm{E}+00 & 39.69 \\ 2.56 \mathrm{E}-03 & 4.26 \mathrm{E}+00 & 7.42 \mathrm{E}+00 & 33.07 \\ 5.12 \mathrm{E}-03 & 5.53 \mathrm{E}-01 & 7.98 \mathrm{E}+00 & 130.00\end{array}$

is of 98 . 
WHC-SD-WM-CN-048 ReV C

\section{Case 7: Nominal Spray Leak}

$$
86 \text { of } 98
$$


SPRAY Versi@in 3.2

August 31, 1995

Spray Leak Code

Produced by Radiological \& Toxicologica* Analysis

Westinghouse Hanford Company

Run Date $=06 / 04 / 96 /$

Run Time $=17: 43: 44.30$

INPUT ECHO:

C Case 7: Spray leak using nominal valıes

c SPRAY Code Version 3.2 Input File

$c$

MODEL OPTIONS:

C mode - program calculation mode

c $\quad=1$ for orifice leak

c $\quad=2$ for slit leak

c ifric - integer flag for friction factor

$=0$ for program selection

= 1 for laminar relation

$=2$ for turbulent relation

iopt - integer flag for flow determination

$=0$ for optimal diameter search given initial guess diameter and Re

$=1$ for flow based on user specified diameter

$=2$ for flow based on user specified Reynold's number

mode ifric iopt

2001

PARTICLE SIZE DISTRIBUTION TABLE PARAMETERS:

C

\section{Starting}

Particle

Size Geometric Number of

(um) Step Size Intervits

c

\section{$\longdiv { 1 . 0 0 0 0 0 E + 0 1 }$}

$2.00000 E+00$

10

C PARAMETER INPUT:

c.

c Initial slit

c Width or

c Orifice Dia.

S1 it

Length

S1it o-

Orific:

Depth

Reynold's 
WHC-SD-WM-CN-O48 ReVO

\begin{tabular}{|c|c|c|c|c|}
\hline$c$ & (in) & (in) & (in) & Number \\
\hline & $\overline{1.00000 \mathrm{E}-02}$ & $\overline{1.00000 \mathrm{E}+00}$ & $\overline { 2 . 1 6 0 } \longdiv { 0 E - 0 1 }$ & $2.00000 E+03$ \\
\hline & & $\begin{array}{l}\text { Absolute } \\
\text { Surface }\end{array}$ & & \\
\hline$C$ & & $\begin{array}{l}\text { Roughness } \\
\text { (in) }\end{array}$ & $\begin{array}{l}\text { Contriction } \\
\text { Coefficient }\end{array}$ & $\begin{array}{l}\text { Velocity } \\
\text { Coefficient }\end{array}$ \\
\hline C & Pressure & 0.00006 tube & 0.61 and & 0.98 for sharp edge orifice \\
\hline & Differential & 0.0018 steel & 1.00 & 0.98 for rounded orifice \\
\hline & (psi) & 0.0102 iron & 1.00 and & 0.82 for square edge orifice \\
\hline & $1.50000 E+02$ & $\overline{1.80000 \mathrm{E}-03}$ & $\overline{1.000} \sqrt{0 E+00}$ & $8.20000 \mathrm{E}-01$ \\
\hline C & $\begin{array}{l}\text { Fluid } \\
\text { Density } \\
\text { (g/cc) }\end{array}$ & $\begin{array}{l}\text { Dynamic } \\
\text { Viscosity } \\
\text { (centi-poise) }\end{array}$ & $\begin{array}{l}\text { Respilable } \\
\text { Diame:er } \\
(\mu \mathrm{m})\end{array}$ & $\begin{array}{l}\text { RR Fitting } \\
\text { Constant } \\
\text { (q) }\end{array}$ \\
\hline & $\overline{1.20000 \bar{E}+00}$ & $1.00000 E+00$ & $\overline{2.7000(\overline{0 E}+01}$ & $\overline{2.40000 E+00}$ \\
\hline$c$ & $\begin{array}{l}\text { Ambient } \\
\text { Density } \\
\text { (g/cc) }\end{array}$ & $\begin{array}{l}\text { Wind } \\
\text { Speed } \\
(\mathrm{m} / \mathrm{s})\end{array}$ & & \\
\hline & $\overline{1.22000 \mathrm{E}-03}$ & $1.00000 E+00$ & & \\
\hline
\end{tabular}

\section{MESSAGES:}

Slit Mode?

User specified orifice diameter or slit width.

OUTPUT:

Liquid Velocity $=8.53 \mathrm{E}+01 \mathrm{ft} / \mathrm{s} \quad 2.60 \mathrm{E}+01 \mathrm{~m} / \mathrm{s}$

Reynolds Number $=1.57 \mathrm{E}+04$ Turbulent Flow

Sauter Mean Diameter $=1.29 \mathrm{E}+02 \mu \mathrm{m}$

Mass Median Diameter $=1.69 \mathrm{E}+02 \mu \mathrm{m}$

Characteristic Dia. $=1.97 \mathrm{E}+02 \mu \mathrm{m}$

Respirable Fraction $=8.46 \mathrm{E}-03$

Total Leak Rate $=2.66 \mathrm{E}+00 \mathrm{gpm} \quad 1.68 \mathrm{E}-04 \mathrm{m3} / \mathrm{s} \quad 2.01 \mathrm{E}+02 \mathrm{~g} / \mathrm{s}$

Respirable Leak Rate $=2.25 \mathrm{E}-02 \mathrm{gpm} \quad 1.42 \mathrm{E}-06 \mathrm{~m} 3 / \mathrm{s} \quad 1.70 \mathrm{E}+00 \mathrm{~g} / \mathrm{s}$

Jet Rise $=2.09 \mathrm{E}+00 \mathrm{ft} \quad 6.36 \mathrm{E}-01 \mathrm{~m}$

Particle Section Cumulative

Diameter Release Release Cumulative

Sections Rate Rate Percent

(m) $\quad(\mathrm{kg} / \mathrm{s}) \quad(\mathrm{kg} / \mathrm{s}) \quad(\%)$

\begin{tabular}{|c|c|c|c|}
\hline $\begin{array}{l}1.00 \mathrm{E}-05 \\
2.00 \mathrm{E}-05 \\
4.00 \mathrm{E}-05 \\
8.00 \mathrm{E}-05 \\
1.60 \mathrm{E}-04 \\
3.20 \mathrm{E}-04\end{array}$ & $\begin{array}{l}1.58 \mathrm{E}-04 \\
6.73 \mathrm{E}-04 \\
3.52 \mathrm{E}-03 \\
1.76 \mathrm{E}-02 \\
6.98 \mathrm{E}-02 \\
1.01 \mathrm{E}-01\end{array}$ & $\begin{array}{l}1.58 \mathrm{E}-04 \\
8.31 \mathrm{E}-04 \\
4.35 \mathrm{E}-03 \\
2.19 \mathrm{E}-02 \\
9.17 \mathrm{E}-02 \\
1.93 \mathrm{E}-01\end{array}$ & $\begin{array}{r}.08 \\
. .41 \\
. .16 \\
1) .88 \\
4.5 .57 \\
9.97\end{array}$ \\
\hline
\end{tabular}


WHC-SI-WM-CN-O48 RivC

$6.40 \mathrm{E}-04$
$1.28 \mathrm{E}-03$

8. $12 \mathrm{E}-03$

2.01E-01

130.00

2. $56 \mathrm{E}-03$

1. $49 \mathrm{E}-08$

$0.00 E+00$

2.01E-01

130.00

5.12E-03

$0.00 E+00$

2.01E-01

130.00

2.01E-01 130.00

89 क 98 
WHC-SD-WM-CN-048, Rev. O

\section{Appendix D}

Time Dependent Atmc spheric Dispersion Coefficients

$$
46 \text { of } 98
$$




\section{WHC-SL-WM-CN-048 Rev C}

\section{Appendix D}

This appendix determines tille dependent $X / Q$ 's for the onsite and offsite receptor locations. Time dependelit $X / Q^{\prime} s$ are used to model releases of differing durations, and to model releases where release rates vary with time.

Table D-1 summarizes the acute $(99.5 \%)$, the acute with plume meander, the annual average, and the puff $: / Q^{\prime}$ s for the onsite receptor. Table $D-2$ summarizes these same values for the offsite receptor. Tables $D-1$ and $D-2$ were reproduced from WHC-SD-WM-SAIR-016. The acute $X / Q^{\prime} S$ are appropriate for releases that last less than 1 hoir. (Puff release $X / Q^{\prime}$ 's are not applicable to this accident analysis). The icute $X / Q^{\prime} s$, with plume meander, are appropriate for releases that do lot vary substantially and that last for 1 to 2 hours. For releases that last longer than 2 hours, it is necessary to determine longer term $X / Q^{\prime} s$. Thi: is done by logorithmically interpolating between the $2-h X / Q^{\prime}$ and the annui 1 average $X / Q^{\prime}$ for the given receptor location, in accordance with the nethodology outlined in SARR-016. A logarithmic interpolation gives tle following equation, where 8760 is the number of hours in a year:

$$
\frac{\log \left(X / Q^{\prime} \text { at } 2 h\right)-\log \left(X / Q^{\prime} \text { at } \times h\right) \quad \log (2)-\log (x)}{\log \left(X / Q^{\prime} \text { at } 2 h\right)-\log \left(X / Q^{\prime} \text { ann. avg }\right) \log (2)-\log (8760)}
$$

Example calculation. Using the values in Tables D-1 and D-2, a 12-h onsite $X / Q^{\prime}$ calculation would be set up as follows:

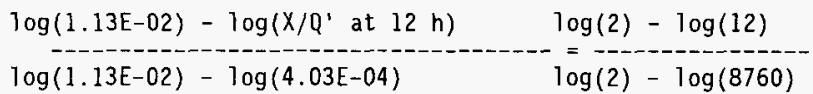

Rearranging and taking the antilog gives a $12-h$ onsite $X / Q^{\prime}$ of $5.54 \mathrm{E}-3 \mathrm{~s} / \mathrm{m}^{3}$.

Table $D-3$ summarizes the onsite and offsite $X / Q$ 's for potential time periods of interest in the accident analysis. The $X / Q^{\prime} s$ for release durations longer than 2 hours were interpolated as shown in the example calculation above. $X / Q^{\prime}$ corresponding to release duration less than 2 hours were taken directly from tables $D-1$ and $D-2$. The $X / Q^{\prime} 5$ in Table $D-3$ are applied in the accident analysis in a conservative manner. For releases that vary with time, the release is broken down into logical increments (e.g., 0 to $2 \mathrm{~h}$ release, 2- to 12- $h$ release, etc.), with the appropriate duration $X / Q$ 's applied to each increment. The short term (larger) $X / Q$ 's are applied to the increments of the release where the release rate is the highest. 
$W H C-S D-W M-C N-048$ Rev 0

Table D-1. Centeritine Atmospheric Dispersion Coefficients for a 200 Area Tank I'arm Acute, Ground-Level Release.

\begin{tabular}{|c|c|c|}
\hline Maximum individual & $\begin{array}{c}\text { Bounding } \\
\text { integrated } \\
x / Q^{\prime}\left(\mathrm{s} / \mathrm{m}^{3}\right)\end{array}$ & $\begin{array}{c}\text { Bounding integrated } \\
x / Q^{\prime}\left(\mathrm{s} / \mathrm{m}^{3}\right) \\
\text { with plume meander }\end{array}$ \\
\hline $\begin{array}{c}\text { Onsite } \\
\text { sector and distance }\end{array}$ & $\begin{array}{c}41 \mathrm{E}-02 \\
\mathrm{E} 100 \mathrm{~m}\end{array}$ & $\begin{array}{c}1.13 \mathrm{E}-02 \\
\mathrm{ESE} 100 \mathrm{~m}\end{array}$ \\
\hline $\begin{array}{c}2.83 \mathrm{E}-5 \\
\text { 0ffsite } \\
\text { sector and distance }\end{array}$ & $\begin{array}{c}2.12 \mathrm{E}-05 \\
\mathrm{~N} 8760 \mathrm{~m}\end{array}$ & $\mathrm{~N} 8760 \mathrm{~m}$ \\
\hline
\end{tabular}

NOTE: The information in this table is from WHC-SD-WM-SARR-016, 1996, Tank Waste Compositions and Atmospheric Dispersion Coefficients for Use in Accelerated Safety Analys is Consequence Assess nents, Westinghouse Hanford Company, Richland, Washington.

$E=$ east

$E S E=$ east, southeast.

$N=$ north.

Table D-2. Chronic Annual Average Atmospheric Dispersion Coefficients for 200 Area Tank Farms.

\begin{tabular}{|c|c|}
\hline Maximum indivilual & $\begin{array}{c}\text { Integrated } \\
x / Q^{1}\left(\mathrm{~s} / \mathrm{m}^{3}\right)\end{array}$ \\
\hline $\begin{array}{c}\text { Onsite } \\
\text { sector and distance }\end{array}$ & $\begin{array}{c}4.03 \mathrm{E}-04 \\
\text { ESE } 100 \mathrm{~m}\end{array}$ \\
\hline $\begin{array}{c}\text { Offsite } \\
\text { sector and distance }\end{array}$ & $\begin{array}{l}1.24 \mathrm{E}-07 \\
\mathrm{E} 12,630 \mathrm{~m}\end{array}$ \\
\hline
\end{tabular}

NOTE: The information $i$, this table is from WHC-SD-WM-SARR-016, 1995, Tank Waste Compositions and Atmospheric Dispersion Coefficients for Use in Accelerated Safety Ana ys is consequence Assessments, West inghouse Hanford Company, Richland, Wa ihington. $E=$ east.

ESE $=$ east, southeast. 
WHC-SD-WM-CN-O48 REV.C

Table D-3. X/Q's for Various Time Periods, Onsite and Offsite

\begin{tabular}{|c|c|c|}
\hline Receptor Location & Rele ase duration (h) & $X / Q^{\prime}\left(\mathrm{s} / \mathrm{m}^{3}\right)$ \\
\hline \multirow[t]{8}{*}{ Onsite } & $<1$ & $3.44 \mathrm{E}-2$ \\
\hline & $1-2$ & $1.13 \mathrm{E}-02$ \\
\hline & 4 & $8.58 \mathrm{E}-03$ \\
\hline & 6 & $7.30 \mathrm{E}-03$ \\
\hline & 8 & $6.51 E-03$ \\
\hline & 10 & $5.96 \mathrm{E}-03$ \\
\hline & 11 & $5.74 \mathrm{E}-03$ \\
\hline & 12 & $5.54 \mathrm{E}-03$ \\
\hline \multirow[t]{15}{*}{ offsite } & $<1$ & $2.83 \mathrm{E}-05$ \\
\hline & $1-2$ & $2.12 \mathrm{E}-05$ \\
\hline & 4 & 1. $39 E-05$ \\
\hline & 6 & $1.08 \mathrm{E}-05$ \\
\hline & 8 & $9.06 \mathrm{E}-06$ \\
\hline & 10 & $7.90 \mathrm{E}-06$ \\
\hline & 12 & $7.07 \mathrm{E}-06$ \\
\hline & 14 & $6.43 E-06$ \\
\hline & 16 & $5.92 \mathrm{E}-06$ \\
\hline & 18 & $5.51 E-06$ \\
\hline & 20 & $5.17 E-06$ \\
\hline & 22 & $4.87 \mathrm{E}-06$ \\
\hline & 23 & $4.74 \mathrm{E}-06$ \\
\hline & 24 & $4.62 E-06$ \\
\hline & 72 & $2.36 \mathrm{E}-06$ \\
\hline
\end{tabular}


$W H C-S D \cdot W M-C N-048$, Rev. 0

Appendix E

Psychrometric Chart

94 क 98 
WHC-SD-WM-CN-OY8 RevC

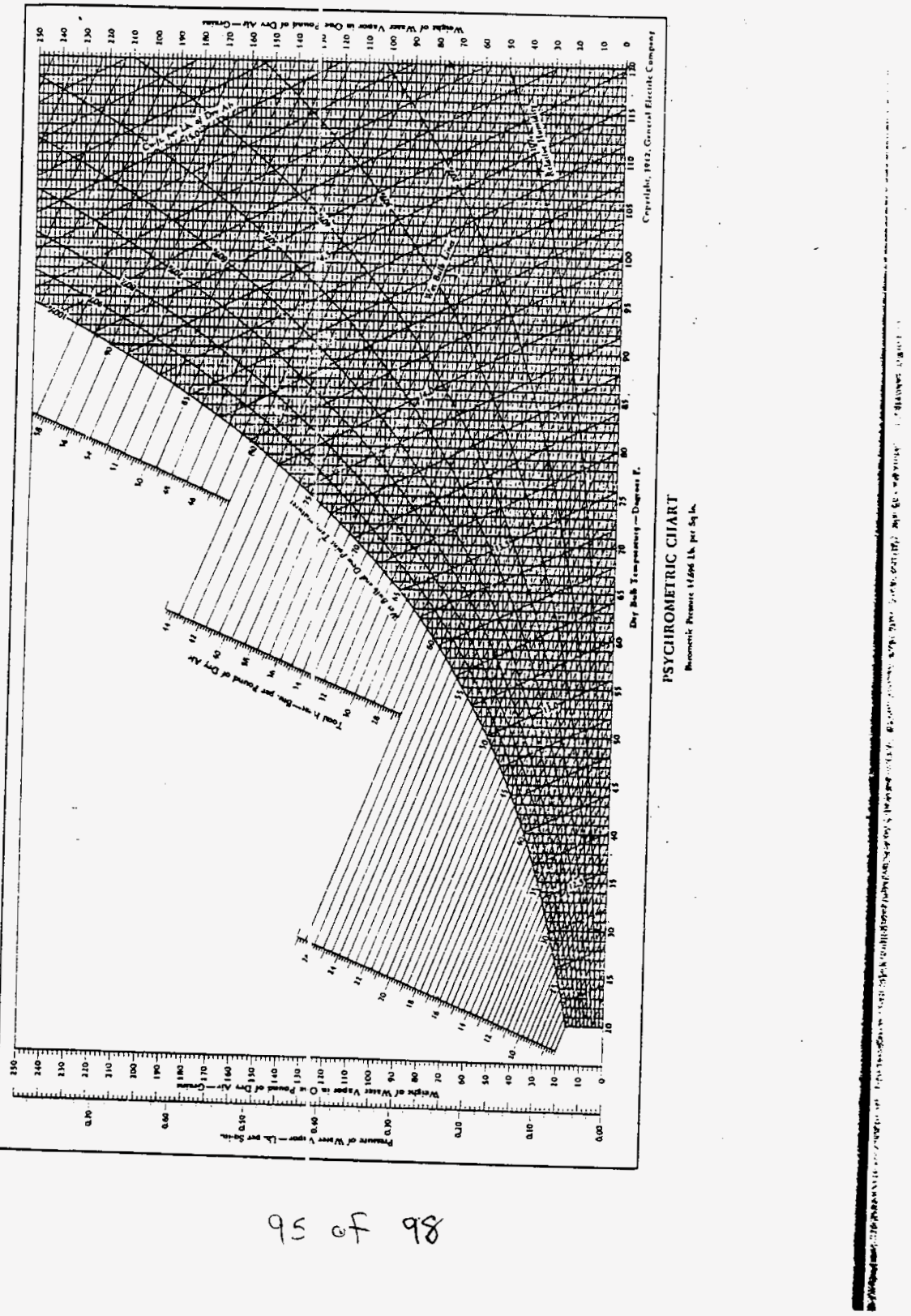




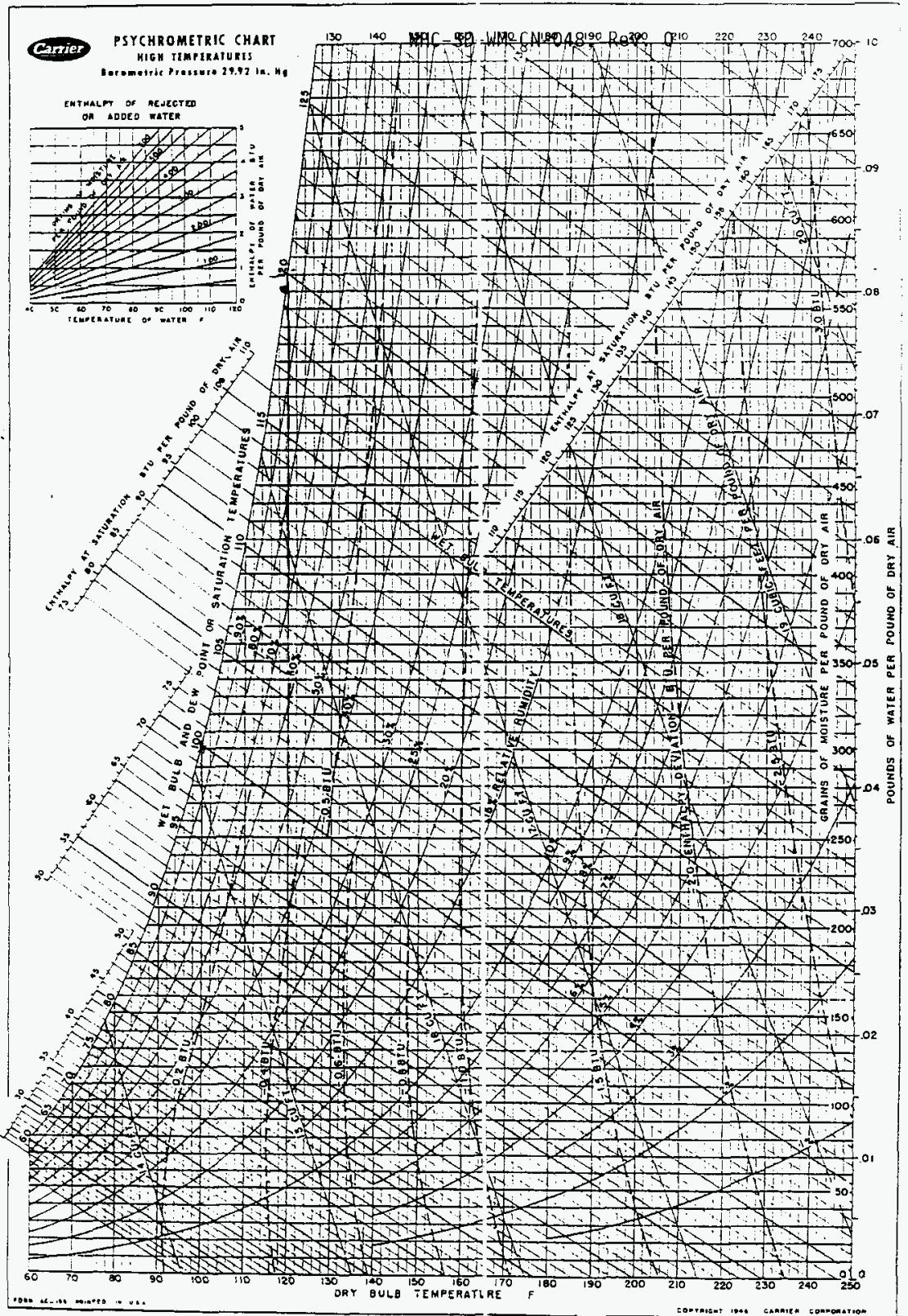

9 of 98 
WHC-SD.WM-CN-048, Rev. 0

Appendix $F$

Peer Review Checklist 
WHC-SD-WM-CN-048, Rev. 0

PEER REVIEW CHECKLIST

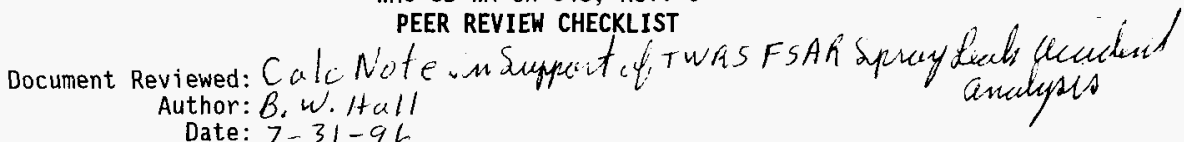

scope of Review: As indicated be lcW

$\frac{\text { Yes No NA }}{\text { [ ] [ ] IX }}$

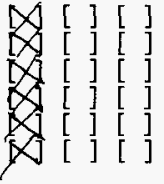

[ ] [ ]

$\infty][][$

$\mathbb{X}[$ [ ] [ ]

议 [ ] [ [ [ ]

[ ] [ ] $\mathbb{X}$
Previous reviews :omplete and cover anaiysis, up to scope of this review, with no gaps.

Problem completel:" defined.

Accident scenario: developed in a clear and logical manner.

Necessary assumpt ons explicitly stated and supported.

Computer codes anci data files documented.

Data used in calcl lations explicitly stated in document.

Data checked for consistency with original source information as applicable.

Mathematical derilations checked including dimensional consistency of results.

Models appropriate and used within range of validity or use outside range of $\epsilon$ stablished validity justified.

Hand calculations checked for errors. Spreadsheet results should be treated exactly the same as hand calculations.

Software input correct and consistent with document reviewed.

Software output consistent with input and with results reported in document reviewed.

Limits/criteria/glidelines applied to analysis results are appropriate and $r \in$ ferenced. Limits/criteria/guidelines checked against $r \in$ ferences.

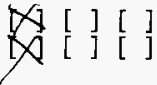

$[\mathrm{c}[\mathrm{]}] \mathrm{X}$

[ ] [ ]

[ ] [ ] Review calculations, comments, and/or notes are attached.

\section{[ ] [ ] Document approved.}

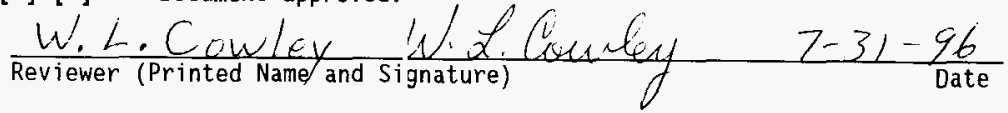




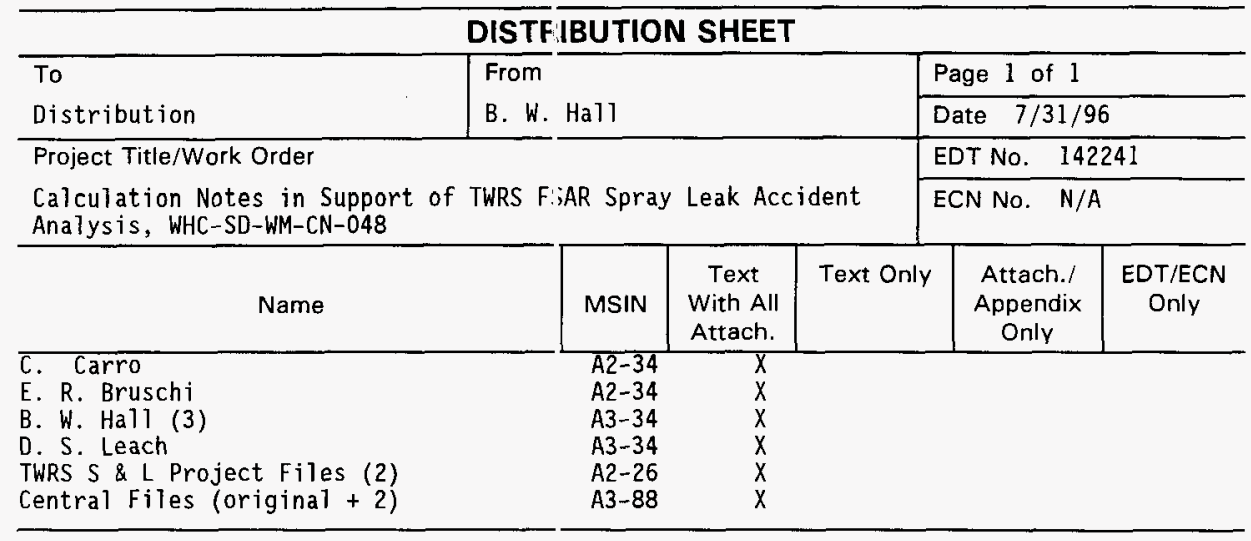

